
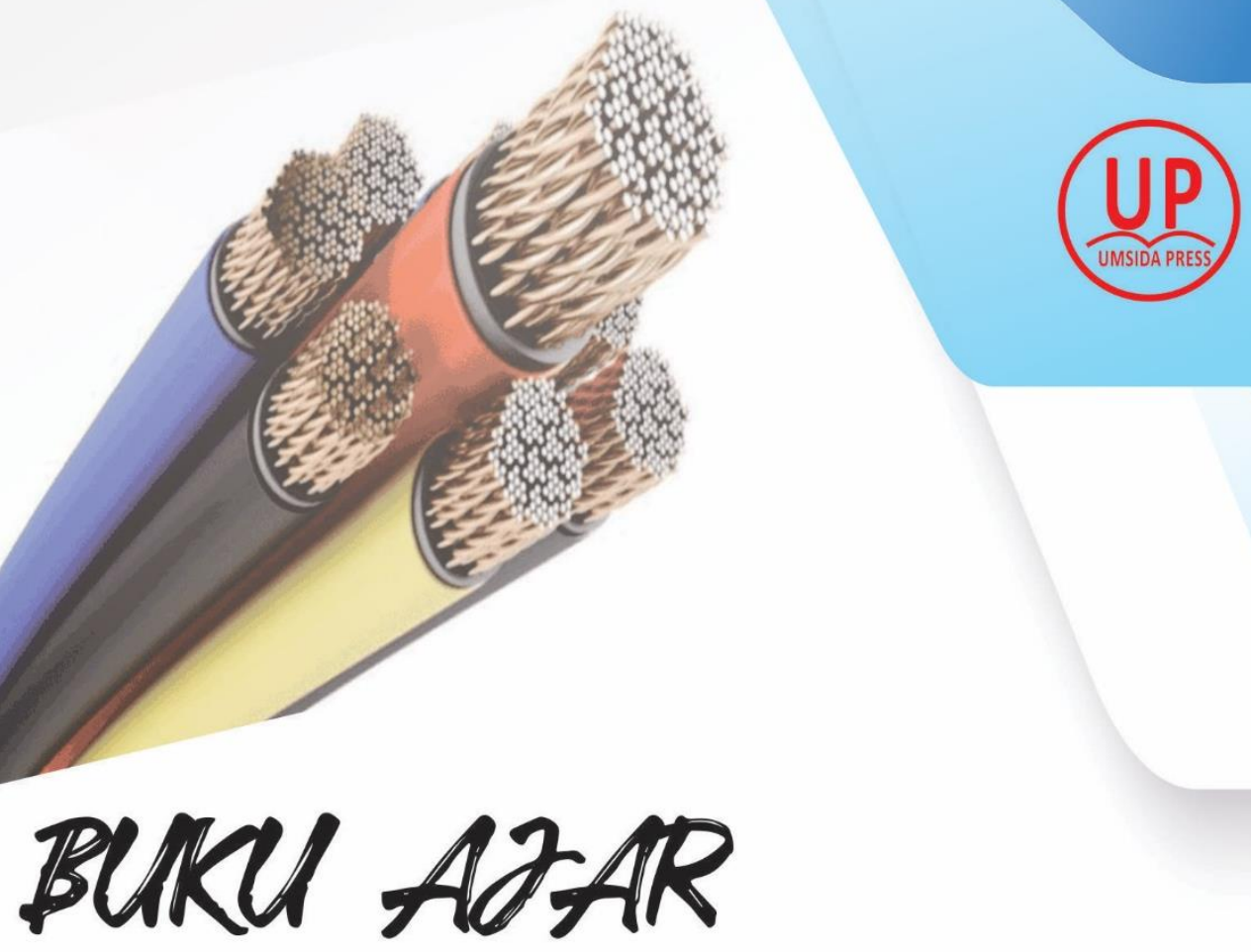

\title{
BAHAN-BAHAN LISTRIK
}

(STRUKTUR ATOM DAN JENIS BAHAN)

Ir. Jamaaluddin, M.M

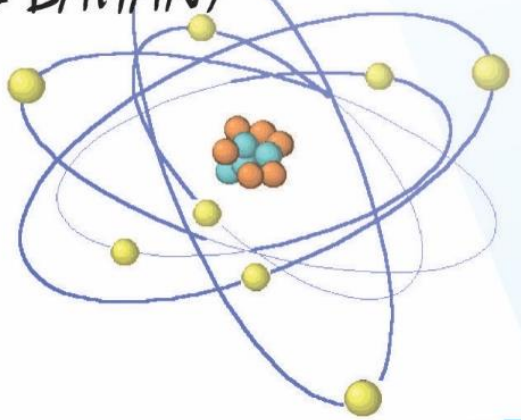

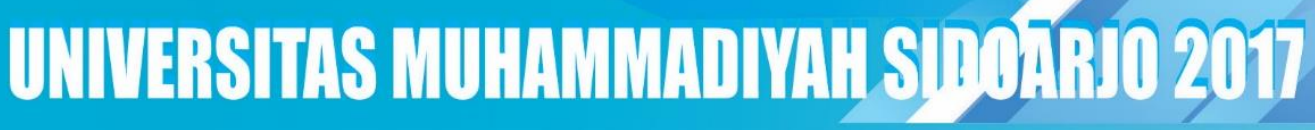




\section{BUKU AJAR \\ STRUKTUR ATOM DAN JENIS BAHAN}

Disusun oleh:

Jamaaluddin

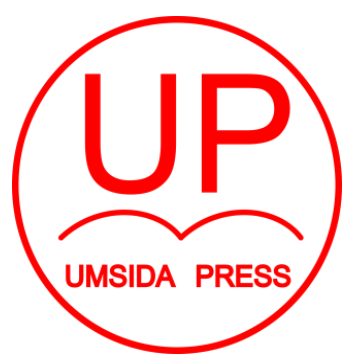

Diterbitkan oleh UMSIDA PRESS

Jl. Mojopahit 666 B Sidoarjo

ISBN: 978-602-5914-37-9

Copyright@2018.

Authors

All rights reserved 


\section{BUKU AJAR \\ STRUKTUR ATOM DAN JENIS BAHAN}

\section{Penulis :}

Jamaaluddin

\section{ISBN :}

978-602-5914-37-9

\section{Editor :}

Septi Budi Sartika, M.Pd

M. Tanzil Multazam, S.H., M.Kn.

\section{Copy Editor :}

Fika Megawati, S.Pd., M.Pd.

Design Sampul dan Tata Letak :

Mochamad Nashrullah, S.Pd

\section{Penerbit :}

UMSIDA Press

\section{Redaksi :}

Universitas Muhammadiyah Sidoarjo

Jl. Mojopahit No 666B

Sidoarjo, Jawa TImur

Cetakan pertama, Agustus 2018

(C) Hak cipta dilindungi undang-undang

Dilarang memperbanyak karya tulis ini dengan suatu apapun tanpa ijin tertulis dari penerbit. 


\section{KATA PENGANTAR}

Bismillaahrrahmaanirrohiim

Assalamu 'alaikum, wr, wb

Dengan mengucapkan syukur alhamdulillah penulis telah menyelesaikan buku ajar BAHAN - BAHAN LISTRIK ini. Buku ini dibuaat dengan harapan memberikan kemudahan bagi siapa saja khususnya mahasiswa yang sedang kuliah untuk mendapatkan gambaran mengenai ilmu BAHAN - BAHAN LISTRIK.

Buku ini akan menyampaikan beberapa teori yang berkaitan dengan proses bagaimana terbentuknya material yang berkaitan dengan Listrik, dan juga memberikan pandangan dan penjelasan yang sangat gamblang mengenai Bahan bahan yang sering dipergunakan dalam pekerjaan yang berkaitan dengan sistem kelistrikan. Bagaimana cara memakainya, dan batasan batasan kemampuan apa yang terkandung pada material tersebut.

Mulai dari bahan konduktor, isolator, semi konduktor, super konduktor, serat optik dan magnet, semuanya akan dikupas mulai dari unsur pembentuknya, karakteristik unssur pembentuk, maupun kalau sudah berbentuk material atau bahan sampai dengaan pemanfaatannya untuk apa akan dijelaskan pada buku ini.

Buku ini sangat bermanfaat untuk para mahasiswa dan masyarakat umum yang tertaarik mendalami masalah kelistrikan utamannya pada pengetahuana bahannya.

Akhirnya penulis menyampaikan selamat membaca...

Walhamdulillaahirobbil 'alamiin

Wassalamu 'alaikum, wr, wb

Penulis 


\section{DAFTAR ISI}

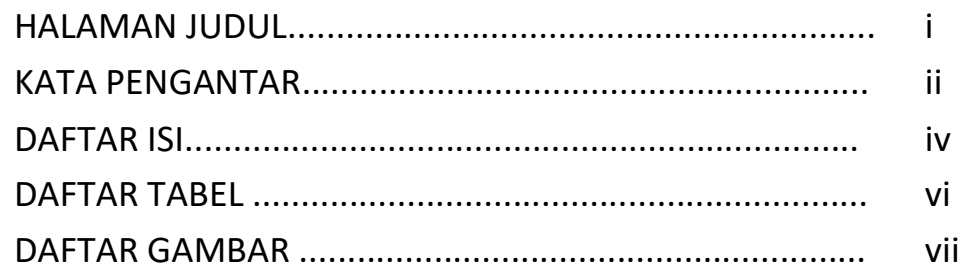

BAB I : Struktur Atom............................................. 1

1.1. Struktur Atom............................................... 1

1.2. Model Atom................................................. 2

1.3. Komposisi Atom............................................ 8

1.4. Nomer Atom dan Nomer Massa..................... 12

1.5. Orbital Elektron.......................................... 16

1.6. Konfigurasi Elektron.................................... 22

1.7. Pita Energy................................................ 25

1.8. Tugas..................................................... 30

BAB II : Benda dan Bahan Listrik.............................. 31

2.1. Pentingnya Pengetahuan Tentang Bahan Listrik 31

2.2. Pengelompokan Bahan Listrik........................ 31

2.2.1. Konduktor........................................... 33

2.2.2. Isolator.............................................. 40

2.2.3. Semi Konduktor................................... 46

2.2.4. Magnet................................................ 50

2.2.5. Super Konduktor................................ 53

2.2.6. Serat optik ........................................ 58

2.3. Tugas...................................................... 67

Bab III : Sifat Bahan Listrik .................................. 69 
3.1. Jenis Bahan atau Material.............................. 69

3.2. Jenis Ikatan Antar Atom............................... 70

3.3. Sifat Bahan Listrik............................................ 81

3.3.1.Konduktor........................................... 82

3.3.2.Isolator Listrik......................................... 83

3.3.3.Semi Konduktor ..................................... 85

3.3.4.Keramik .................................................... 93

3.4. Sifat Bahan ..................................................... 97

3.4.1.Sifat Mekanik......................................... 97

3.4.2.Sifat Listrik ............................................. 98

3.5. Tugas.......................................................... 100

DAFTAR PUSTAKA .................................................. 102

OTO BIOGRAFI PENULIS................................................ 104 


\section{DAFTAR TABEL}

Tabel

Hal

1.1 Bilangan Kuantum ............................................ 17

2.1 Mobilitas Semi Konduktor .................................... 48

3.1 Golongaan Kation dan Anion ................................ 72 
Gambar Hal

1.1 Gambaran Atom .............................................. 2

1.2 Model Atom JJ Thompson ...................................... 4

1.3 Model Atom Rutherford......................................... 5

1.4 Model Atom Neils Bohr ........................................... 6

1.5 Model Atom Mekanika Gelombang ....................... 7

1.6 Struktur Atom Karbon ............................................ 8

1.7 Gambaran Dalam Sebuah Atom ............................ 9

1.8 Perikatan Antar Atom ......................................... 10

1.9 Reaksi Kimia Air ................................................. 11

1.10 Ion Positif dan Ion Negatif ................................... 14

1.11 Susunan Periodik Berkala ................................... 15

1.12 Nomer Atom dan Nomer Massa .......................... $\quad 16$

1.13 Posisi Nomer Atom dan Nomer Massa .................. 16

1.14 Kombinasi Bilangan Kuantum .............................. 18

1.15 Representasi Orbital 1s, 2s dan 3 s ...................... 19

1.16 Representasi Orbital 2p; px, py dan pz ................. 20

1.17 Representasi Orbital 3d; Dz2, Dx2-Y2, Dxy, Dxz, Dyz 21

1.18 Representasi Ketujuh Orbital................................. 21

1.19 Tingkat Orbital Elektron...................................... 22

1.20 Konfigurasi Elektron ............................................ 23

1.21 Pita Energi Natrium .......................................... 27

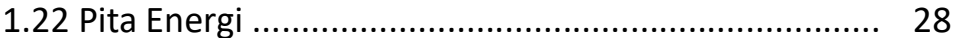

1.23 Pita Energi Konduktor ........................................ 28

1.24 Pita Energi Semi Konduktor ................................. 29

2.1 Material Yang Terdiri Dari Bahan - Bahan Listrik..... 32 
2.2 Salah Satu Contoh Konduktor............................... 34

2.3 Tipe Kabel Yang Sering Dijumpai Di Lapangan.......... 39

2.4 Struktur Material Yang Ada di dalam Konduktor...... 42

2.5 Struktur Penyusun Kabel Coax............................... 43

2.6 Struktur Dua Dimensi Kristal Silikon....................... 46

2.7 Pita Energi Struktur Pita Untuk (A). Bahan

Isolator (B). Bahan Semikonduktor, (C) Bahan Isolator 49

2.8 Pengotoran Semi Konduktor................................ 50

2.9 Jenis - Jenis Magnet........................................... 51

2.10 Super Konduktor................................................ 54

2.11 Vektor suhu Bahan Superkonduktor...................... 56

2.12 Grafik Hubungan Antara Suhu Kritis Dan

Suhu Bahan Superkonduktor............................... 57

2.13 Serat Optik..................................................... 59

2.14 Kabel laut yang Mempergunakan Serat Optik........ 63

2.15 Proses Pemasangan Kabel Laut............................. 64

3.1 (a) Molekul Air. (b) Distribusi Ion Pada Molekul Air.. 70

3.2 Ikatan Kimia Dalam Molekul.................................. 70

3.3 Ikatan Ion $\mathrm{NaCl}$ (Natrium Chlorida)........................ 72

3.4 Jenis Ikatan Kovalen............................................ $\quad 74$

3.5 Ikatan Ion .......................................................... 75

3.6 Ikatan Kovalen Tunggal ..................................... 76

3.7 Ikatan Kovalen Rangkap 2................................... 76

3.8 Ikatan Kovalen Rangkap 3................................. 77

3.9 Ikatan Kovalen.................................................... 78

3.10 Ikatan Logam .................................................... $\quad 79$

3.11 Penampang Orbital Atom Magnesium................... 81

3.12 Struktur Atom Silikon Dan Germanium.................. 86

3.13 Struktur Kristal Silikon dengan Ikatan Kovalen........ 87 
3.14 Struktur Kristal Semikonduktor (Silikon) Tipe N....... 88

3.15 Diagram Pita Energi Semikonduktor Tipe N............ 90

3.16 Bahan Semikonduktor Tipe N............................. 90

3.17 Struktur Kristal Semikonduktor (Silikon) Tipe P....... 91

3.18 Diagram Pita Energi Semikonduktor Tipe P............ 92

3.19 Bahan Semikonduktor Tipe P............................... 93 


\section{BAB I}

\section{Struktur Atom}

Tujuan Instruksional :

Setelah mempelajari Bab ini, di harapkan pembaca dapat memahami :

1. Sistem Periodik Unsur

2. Model atom dan menentukan Nomer Massa dan Nomer Atom

3. Bagaimana elektron berjalan mengelilingi orbitnya.

4. Bagaimana pita energi dapat menentukan sifat bahan.

\subsection{Struktur Atom.}

Pada kehidupan sehari hari, manusia tidak bisa terlepas dari benda - benda. Benda - benda tersebuut terdiri dari partikel partikel. Bagian terkecil dari partikel itu adalah atom. Pada waktu mendatang tidak dipungkiri akna ditemukan partikel penyusun yang lebih kecil dari atom.

Atom ini mempunyai struktur yang dikenal dengan sebutan struktur atom, Struktur atom ini terdiri dari inti atom beserta awan elektron bermuatan negatif yang mengelilinginya. Sedangkan inti atom mengandung muatan campuran proton yang bermuatan positif dan neutron yang bermuatan netral.

Sebagai gambaran jika jari tangan ditusuk dengan sebuah jarum, mka akan keluar setetes darah dari jari tangan tersebut. Setetes darah yang keluar dari jari tersebut terdiri dari berjuta - juta sel darah, dimana masing - masing sel darah tersebut terdiri dari berjuta juta atom. Sedangkan atom yang kecil tersebut terdiri dari inti dan awan elektron. Dari contoh ini dapat di pahami betapa kecilnya atom tersebut. Sedangkan di Dunia ini seluruh benda benda yang ada di dalamnya terdiri dari struktur yang sedemikian itu. 
Maka jika ingin mempelajari ilmu tentang materi dari seluruh bahan - bahan yang ada di muka bumi ini, maka dimulai dengan mempelajari bagaimana struktur atomnya. Dari sifat atom yang ada maka kita dapat mengetahui sifat dari suatu ateri.

Begitu juga dengan bahan - bahan listrik yang akan dipelajari disini, bahan listrik mempunyai sifat konduktor (Dapat megghantarakan arus listrik), Isolator (Menahan arus listrik), semi konduktor (Penggabungan sifat isolator dan konduktor) dan beberapa sifat listrik lainnya. Kenapa dapat memunculkan sifat yang sedemikian banyak itu? Hal ini dikarenakan berbagai macam sifat struktur atomnya[1].

1.10 .

odel Atom

1.10.1.

odel Atom Demokritus(400 SM).

Demokritus pada tahun 400 SM, menyatakan bahwaa benda tersusun dari partikel yang kecil yang disebut dengan atomos. Dinyatakan bahwa atom adalah Zarah yang terkecil dan diskrit. Sebagai gambaran dapat dilihat sebagaimana pada gambar 1.1.

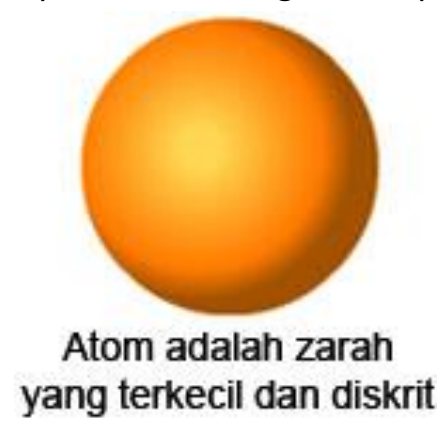

Gambar 1.1. Gambaran atom 


\subsection{2.}

odel Atom John Dalton (1808).

Pada perkembangannya Model Atom John Dalton (1766 $1844)$, tepatnya pada tahun 1808 , menyampaikan teorinya yang lebih maju dari penemu sebelumnya (Demokritus), dengan pemikiran - pemikiran sebagai berikut :

1. Atom adalah bagian terkecil dari unsur.

2. Atom tidak dapat diciptakan, dimusnahkan, terbagi lagi diubah menjadi zat lain.

3. Atom - atom suatu unsur adalah sama dalam segala hal, tetapi berbeda dengan atom atom unsur lain.

Model Atom John Dalton menjelaskan bahwa atom merupakan bagian terkecil dari suatu unsur. Bahwa materi yang terdiri dari partikel - partikel dan partikel ini terdiri dari unsur, memiliki bagian terkecil lagi, yaitu atom. Atom ini sudah tidak bisa dipecah lagi menjadi bagian yang lebih kecil, karena dianggap atom ini adalah bagian terkecil suatu unsur.

Menurut John Dalton bahwa atom tidak dapat diciptakan dan dimusnahkan. Dikarenakan atom ini adalah unsur yang terkecil, maka maka atom ini adalah pembentuk materi, dan zat ini ada terlebih dahulu sebelum materi ada, sehingga zat ini juga tidak dapat dimusnahkan. Dikarenakan atom ini adalaah zat terkecil dari suatu materi, maka zat ini tidak dapat berubah menjadi bentuk yang lain. Atom dari masing masing sifat partikel tidak dapat berubah sifatnya sebagaimana atom yang lain.

1.2.3 Model Atom JJ Thomson (1897). 
Model atom JJ Thomson ini lebih maju daripada teori atom yang sebelumnya. Pada tahun $1897 \mathrm{JJ}$ Thomson menyampaikan bahwa : Atom merupakan suatu bola bermuatan positif yang didalamnya tersebar elektron elektron yang bentuknya seperti kismis. Bentuk ini sebagaimana dapat dilihat pada gambar 1.2.

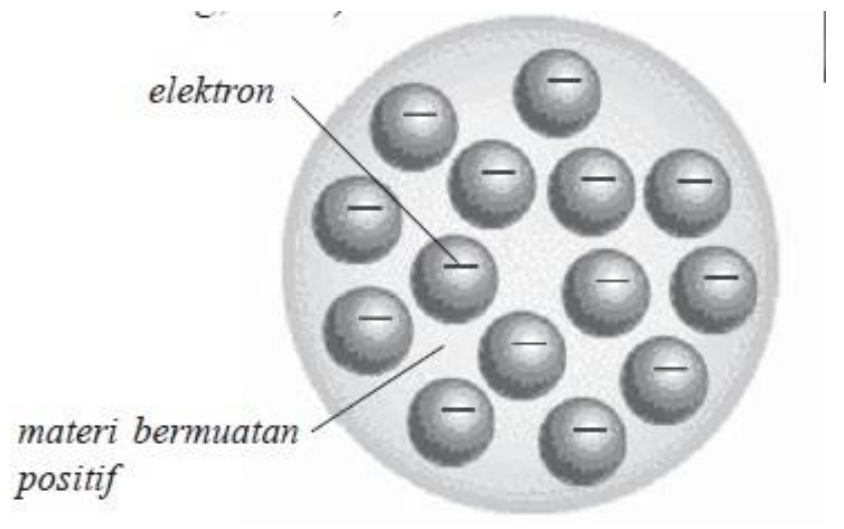

Gambar 1.2. Model Atom JJ Thompson

Pada model atom ini jumlah muatan positif sama jumlahnnya dengan muatan negatif, dikarenakan jumlah muatan negatif dan jumlah muatan positifnya sama, maka atom ini diebut bermuatan netral. Sehingga energi yang muncul akan saling menghilangkan.

\subsubsection{Model Atom Rotherford (1909).}

Pada model Atom Rotherford ini memiliki teori yang lebih modern lagi. Atom disampaikan sudah tidak berisi Muatan positif dan muatan negatif saja, tetapi sudah menyebutkan lintasan lintasan elektron, massa atom dan menemukan nomer atom. 
Model atom rutherfors ini dapat dilihat sebagaimana pada gambar 1.3 .

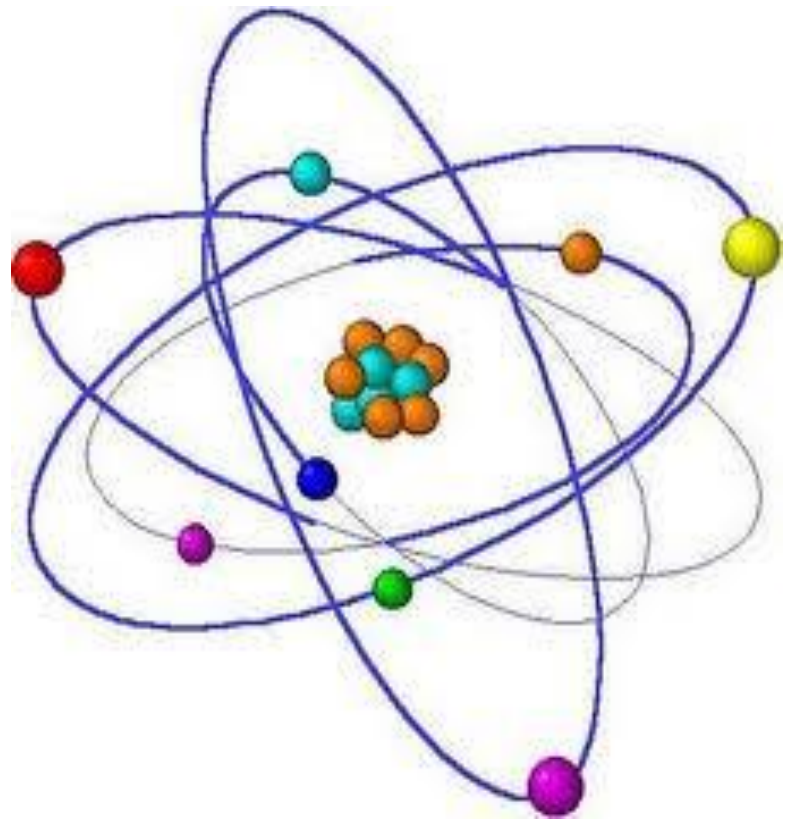

Gambar 1.3. Model Atom Rutherford

Disampaikan oleh Rotherford bahwa :

1. Atom itu terdiri dari inti atom yang mempunyai dimensi yang sangat kecil dengan muatan positif yang massa nya merupakan massa atom tersebut.

2. Inti Atom dikelilingi oleh elektron - elektron yang bergerak mengelilingi inti atom tersebut.

3. Elektron yang mengelilingi inti atom tersebut mempunyai jumlah yang sama dengan jumlah proton yang berada dalam inti dan jumlah inti ini menunjukkan nomer atomnya. 


\subsubsection{Model Atom Neils Bohr (1913).}

Pada model atom Neils Bohr ini penelitian tentang atom semakain mengalami kemajuan, sudah meengetahui tingkatan energi yang ada pada atom tersebut, untuk berpindah dari satu lintasan ke lintasan yang lain. Model atom Neils Bohr dapat dilihat pada gambar 1.4 .

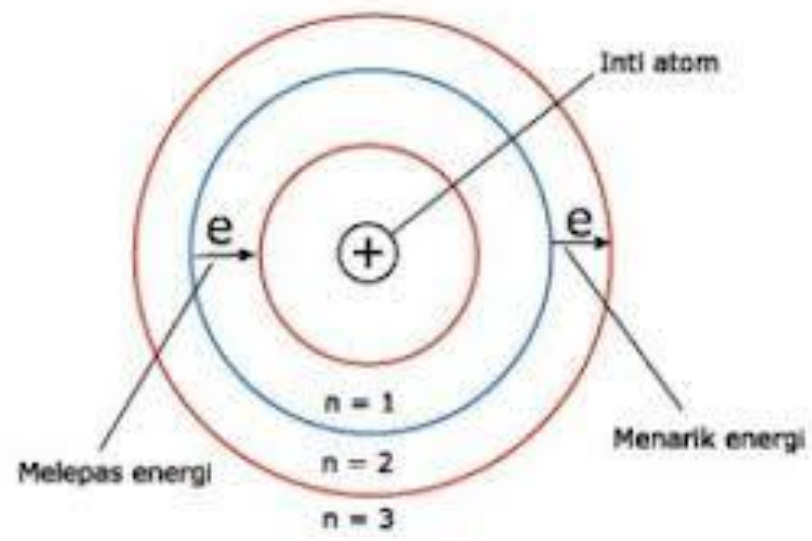

Gambar 1.4. Model Atom Neils Bohr

Pada model atom Neils Bohr ini dijelaskan hal - hal sebagai berikut :

1. Elektron - elektron yang mengelilingi inti atom itu berada pada kulit tertentu dengan memiiki tingkatan energi tertentu tanpa menyerap atau memancarkan energi. 
2. Elektron dapat berpindah dari kulit luar ke kulit yang lebih dalam dengan memancarkan energi (Melepas energi). Sedangkan jika elektron berpindah dari kulit dalam menuju keluar, maka elektron tersebut menarik energi.

\subsubsection{Modell Atom Mekanika Gelombang (1930 an ).}

Perkembangan penelitian tentang atom, semakin lama semakin menunjukkan yang semakin mendalam. Pada tahun 1930 ditemukan model atom Mekanika Gelombang. Pada model atom mekanika gelombang ini dapat dilihat pada Gambar 1.5.

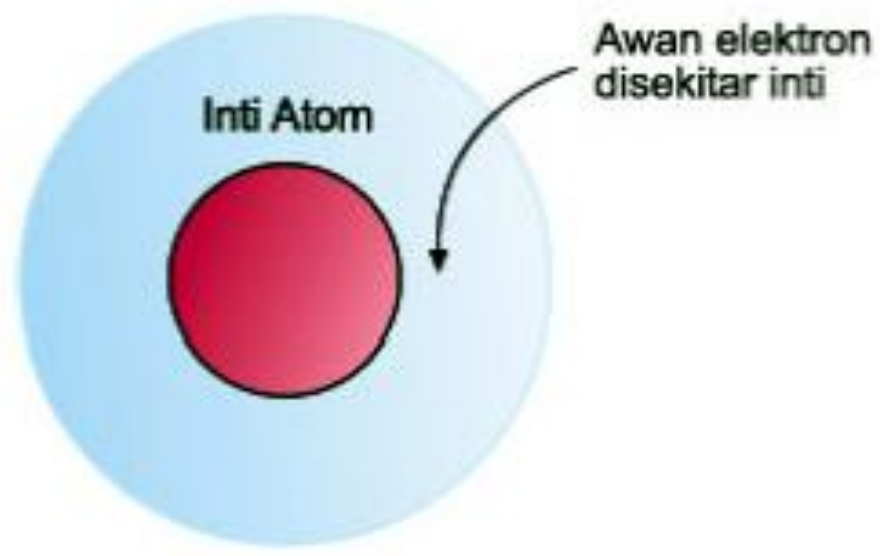

Gambar 1.5. Model Atom Mekanika Gelombang

Dapat dijelaskan bahwa model atom mekanika gelombang ini adalah sebagai berikut :

1. Bahwa elektron yang mengelilingi inti atom tersebut tidak mengorbit pada lintasan tertentu. 
2. Elektron - elektron itu berada pada orbital - orbital dengn tingkat energi tertentu.

3. Sedangkan orbital merupakan daerah dengan kemungkinan terbesar untuk menemukan elektron disekitar inti atom.

\subsection{Komposisi Atom}

Sebagai mana pada perkembangan penelitian tentang atom, yang terakhir yanitu teori mekanika gelombang, maka kita dapat mengetahui bagaimana atom mempunyai struktur. Dengan susuna atom, sebagaimana penjelasan diatas, ada inti atom, yang terdiri dari Neutron dan Proton, dan elektron yang mengelilingi inti atom, berikut adanya energi pada masing masing tingkatan atom maka dapat ditentukan bagaimana struktur atom tersebut.

Struktur atom menunjukkan berapa banyak proton yanag berada pada inti atom, berapa banyak elektron yang mengelilingi inti atom, berikut pada orbit atau lintasan mana elektron itu berada. Pada Gambar 1.6 dapat dilihat contoh sstruktur atom Carbon (C)[2].

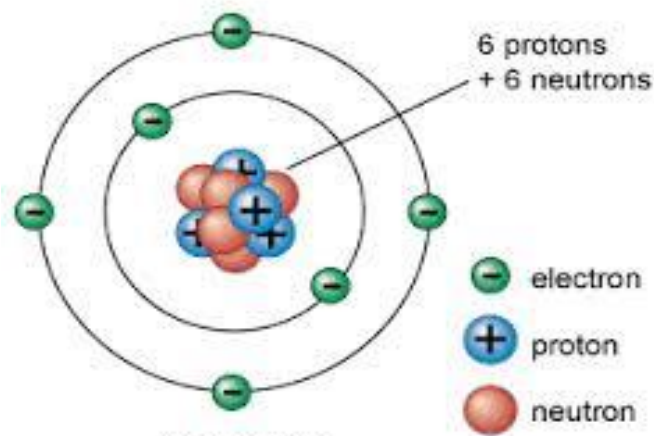

Carbon atom

Gambar 1.6 Struktur Atom Carbon 
Pada gambar 1.6 diatas, dapat dilihat bahwa atom Carbon memiliki jumlah proton 6 dan jumlah neutron 6 dan mempunyai jumlah elektron sebanyak 6. Elektron - elektron yang melingkupinya, berada paada lintasan 1 sebanyak 2 elektron, pada lintasan 2 sebanyak 4 elektron.

Penggambaran secara lebih jelas dari bentuk nyata struktur atom adalah sebagaai pada gambar 1.7.

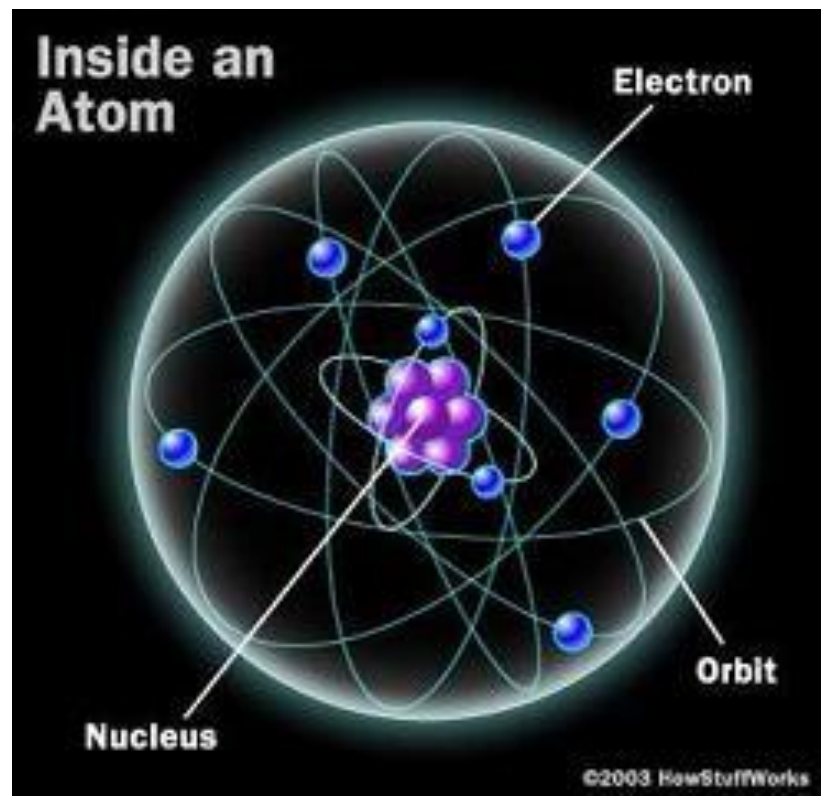

Gambar 1.7 Gambaran Dalam Sebuah Atom 
Pada gambar 1.7 diatas, dapat dilihat bagaimana susunan inti yang terdiri dari neutron dan proton dan posisi dadrai elektron elektronnya.

Bagaimanakah elektron yang mengelilingi inti atom dapat bertahan pada lintasan yang ada pada sekitar inti atom? Elektron - elektron ini dapat bertahan pada lintasan yang ada pada sekeliling inti, ini dikarenakan adanya medan elektromagnetik.

Dengan adanya medan elektromagnetik ini, maka satu atom dapat berikatan dengan atom yang lainnya. Bentuk perikatannya muncul pada lintasan - lintasan elektronnya. Hal ini dapat diihat pada gambar 1.8 .

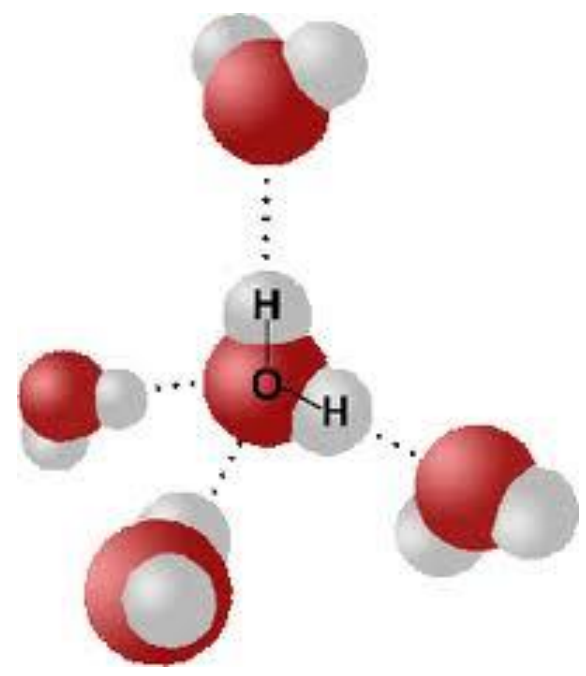

Gambar 1.8 Perikatan Antar Atom 


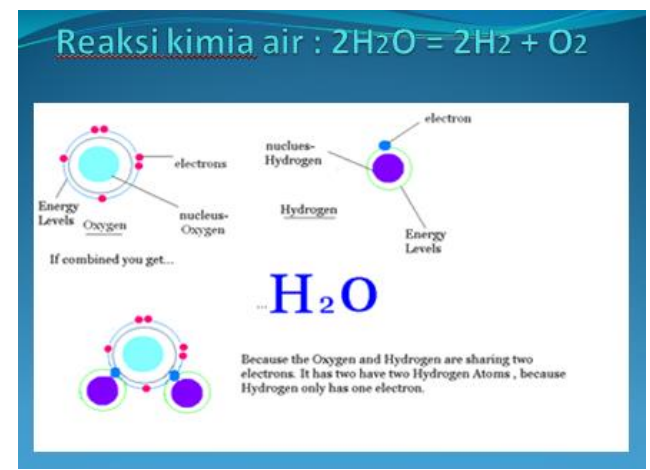

Gambar 1.9 Reaksi Kimia Air

Pada gambar 1.9 dapat dilihat bagaimana atom $\mathrm{O}$ berikatan dengan atom $\mathrm{H}$, dengan komposisi $1 \mathrm{O}$ dan $2 \mathrm{H}$, sehingga menjadi ikatan air $\mathrm{H}_{2} \mathrm{O}$. Ikatan ini namanya senyawa. Senyawa air ini dapat berikatan dengan senyawaa air lainnya, sehingga akan membentuk ikatan sebagaimana pada gambar 1.9.

Atom yang memiliki jumlah proton dan jumlah elektron yang sama maka atom yang berjenis ini disebut dengan atom netral. Sedangan atom yang memiliki jumlah proton dan jumlah elektron yang berbeda, baik bersifat positif maupun negatif itu dinamakan ion. Atom dikelompokkan pada jumlah Proton dan Jumlah Neutron yang ada pada inti atom tersebut.

Jumlah proton ini menentukan jenis unsur kimia atom tersebut. Jumlah Neutron menentukan Isotop (nomer atom sama, tetapi nomer massa berbeda) dari unsur tersebut.

\subsection{Nomer Atom dan Nomer Massa}

Pengertian Nomor Atom dan Nomor Massa - Henry Gwyn-Jeffreys Moseley (1887-1915) pada tahun 1913 menemukan bahwa jumlah muatan positif dalam inti atom merupakan sifat khas masing- 
masing unsur. Atom-atom dari unsur yang sama memiliki jumlah muatan positif yang sama. Moseley kemudian mengusulkan agar istilah nomor atom diberi lambang $\mathrm{Z}$, untuk menyebutkan jumlah muatan positif dalam inti atom[1].

\subsubsection{Nomor Atom (Z)}

Nomor atom (Z) adalah nomor yang menunjukkan jumlah proton (muatan positif) atau jumlah elektron dalam atom tersebut. Nomor atom ini merupakan ciri khas suatu unsur. Oleh karena atom bersifat netral maka jumlah proton sama dengan jumlah elektronnya, sehingga nomor atom juga menunjukkan jumlah elektron. Elektron inilah yang nantinya paling menentukan sifat suatu unsur. Nomor atom ditulis agak ke bawah sebelum lambang unsur.

Nomor atom $(Z)=$ jumlah proton $=$ jumlah elektron

Misalnya, unsur oksigen memiliki nomor atom $8(Z=8)$, berarti dalam atom oksigen terdapat 8 proton dan 8 elektron.

\subsubsection{Nomor Massa (A)}

Selain nomor atom, ada juga yang disebut dengan nomor massa yang biasanya diberi lambang $A$. Massa elektron sangat kecil dan dianggap nol sehingga massa atom ditentukan oleh inti atom yaitu proton dan neutron. Nomor massa ini digunakan untuk menentukan jumlah nukleon dalam atom suatu unsur. Nukleon sendiri adalah partikel penyusun inti atom yang terdiri dari proton dan neutron.

Nomor massa ditulis agak ke atas sebelum lambang unsur. 
Nomor Massa $(A)=$ Jumlah proton $(p)+$ Jumlah neutron $(n)$

Dalam penulisan atom, nomor massa $(A)$ ditulis di sebelah kiri atas, sedangkan nomor atom (Z) ditulis di sebelah kiri bawah dari lambang unsur.

$X=$ lambang unsur

$A=$ nomor massa

$\mathrm{Z}=$ nomor atom

Jumlah Neutron $=$ Nomor massa - Nomor atom

Catatan Kimia :

1. Untuk atom netral, jumlah proton sama dengan jumlah elektron.

2. Untuk ion positif, jumlah proton (muatan positif) lebih banyak daripada elektron (muatan negatif).

3. Untuk ion negatif, jumlah elektron (muatan negatif) lebih banyak daripada proton (muatan positif).

Untuk ion (atom bermuatan positif atau negatif) maka notasi ion, jumlah proton, neutron, dan elektron adalah:

Notasi

1. Ion Positif

Jumlah proton $(p)$

$p=Z$

$p=Z$

Jumlah neutron $(\mathrm{n})$

$\mathrm{n}=\mathrm{A}-\mathrm{Z}$ 
$\mathrm{n}=\mathrm{A}-\mathrm{Z}$

Jumlah elektron (e)

$e=p-q$

$e=p+r$

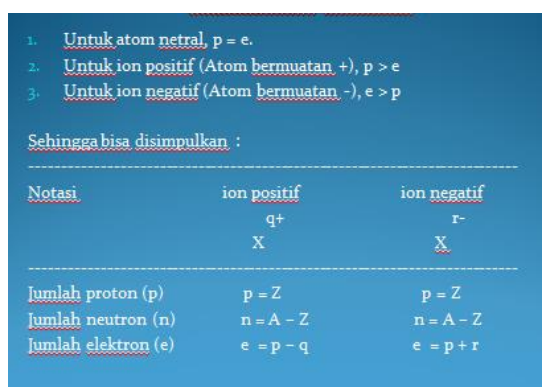

Gambar 1.10 Ion Positif dan Ion Negatif

Contoh:

a. ${ }_{6}^{12} \mathrm{C}$ mempunyai jumlah proton, neutron, dan elektron sebagai berikut.

$\mathrm{p}=\mathrm{Z}=6$

$\mathrm{n}=\mathrm{A}-\mathrm{Z}=12-6=6$

Karena atom netral (tak bermuatan) maka e $=p=6$.

b. Pada ion ${ }^{19}{ }_{9} \mathrm{~F}-$ mempunyai jumlah proton, neutron, dan elektron sebagai berikut.

$\mathrm{p}=\mathrm{Z}=9$

$\mathrm{n}=\mathrm{A}-\mathrm{Z}=19-9=10$

Karena muatan $\mathrm{F}$ adalah -1 maka $r=1$, sehingga:

$e=p+r=9+1=10$ 
c. ${ }_{38}^{88} \mathrm{Sr} 2+$ mempunyai jumlah proton, neutron, dan elektron sebagai berikut.

$\mathrm{p}=\mathrm{Z}=38$

$\mathrm{n}=\mathrm{A}-\mathrm{Z}=88-38=50$

Karena muatan $\mathrm{Sr}$ adalah $2+$, maka $\mathrm{q}=2$ sehingga:

$e=p-q=38-2=36$

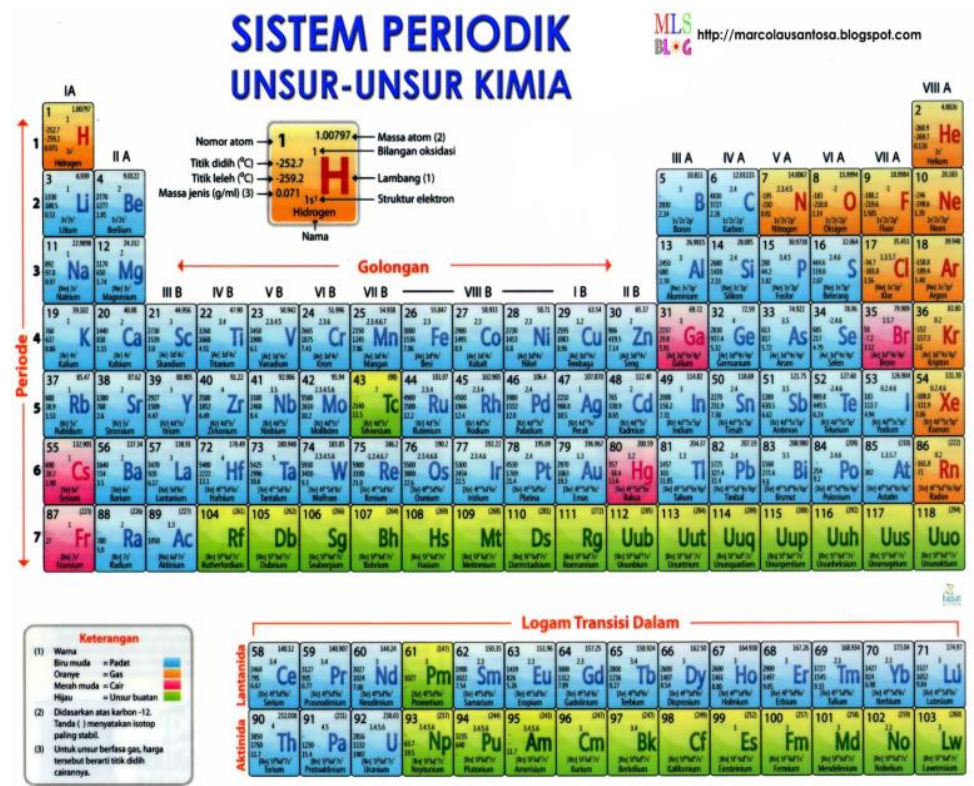

Gambar 1.11 Susunan Periodik Berkala 


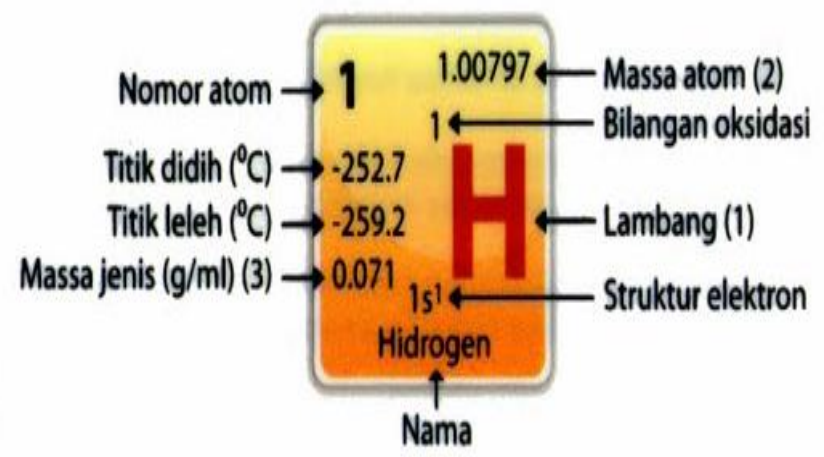

Gambar. 1.12 Nomer atom dan Nomer Massa

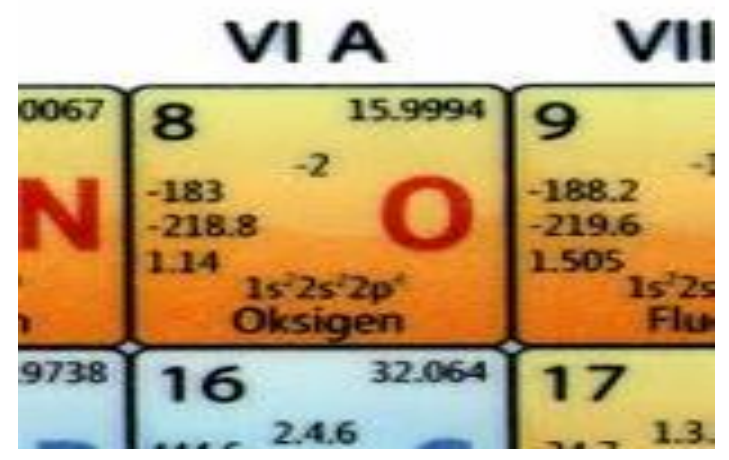

Gambar 1.13 Posisi Nomer Aom dan Nomer Massa

\subsection{Orbital Elektron}

Setiap orbital atom memiliki satu set tiga bilangan kuantum yang unik, antara lain bilangan kuantum utama (n), azimuth (atau momentum angular) (I), dan magnetik $\left(m_{1}\right)$. Ketiga bilangan kuantum tersebut dapat mendeskripsikan tingkat energi orbital dan juga ukuran, bentuk, dan orientasi dari distribusi probabilitas 
radial orbital atom. Lalu, terdapat bilangan yang keempat, yakni bilangan kuantum spin $\left(\mathrm{m}_{\mathrm{s}}\right)$, yang memberikan informasi spin suatu elektron dalam sebuah orbital. Setiap elektron dalam sebuah atom memiliki satu set empat bilangan kuantum yang unik, yakni $n, l, m_{l}$, dan $m_{s .}$ [3]

- Bilangan kuantum utama (n) menunjukkan ukuran dan tingkatkan energi pada tiap tiap lintasan orbitnya. Jika nilai $n$ semakin besar, maka semakin besar ukuran orbital dan semakin tinggi tingkat energinya. Nilai $n$ yang diperbolehkan adalah bilangan bulat positif $(1,2,3$, dan seterusnya).

- Bilangan kuantum azimuth (I) menunjukkan bentuk orbital. Nilai I yang diperbolehkan adalah bilangan bulat dari 0 hingga $\mathrm{n}-1$.

- Bilangan kuantum magnetik $\left(m_{l}\right)$ menunjukkan orientasi orbital. Nilai m। yang diperbolehkan adalah bilangan bulat dari -I hingga + l.

- Bilangan kuantum spin $\left(m_{s}\right)$ menunjukkan arah spin elektron dalam orbital. Nilai $m_{s}$ yang diperbolehkan adalah $+1 / 2$ atau $-1 / 2$.

Bilangan kuantum dengan kombinasi $n, \mathrm{l}$, dan $\mathrm{m}_{\mathrm{l}}$ yang mungkin pada 4 kulit elektron dapat dilihat pada tabel berikut:

Tabel. 1.1 Bilangan Kuantum 


\begin{tabular}{|cccccccc|}
\hline$n$ & Kulit & I & Subkulit & $m_{l}$ & $\begin{array}{c}\text { Jumlah } \\
\text { subkulit }\end{array}$ & $\begin{array}{c}\text { Jumlah } \\
\text { orbital }\end{array}$ & $\begin{array}{c}\text { Jumlah } \\
\text { elektron }\end{array}$ \\
\hline 1 & K & 0 & $s$ & 0 & 1 & 1 & 2 \\
\hline 2 & L & 0 & $s$ & 0 & 1 & 4 & 8 \\
& & 1 & $p$ & $-1,0,+1$ & 3 & & \\
\hline 3 & M & 0 & $s$ & 0 & 1 & & \\
& & 1 & $p$ & $-1,0,+1$ & 3 & 9 & 18 \\
& & 2 & $d$ & $-2,-1,0,+1,+2$ & 5 & & \\
\hline 4 & $\mathrm{~N}$ & 0 & $s$ & 0 & 1 & & \\
& & 1 & $p$ & $-1,0,+1$ & 3 & & \\
& & 2 & $d$ & $-2,-1,0,+1,+2$ & 5 & 16 & 32 \\
& 3 & $f$ & $-3,-2,-1,0,+1,+2,+3$ & 7 & & \\
\hline
\end{tabular}

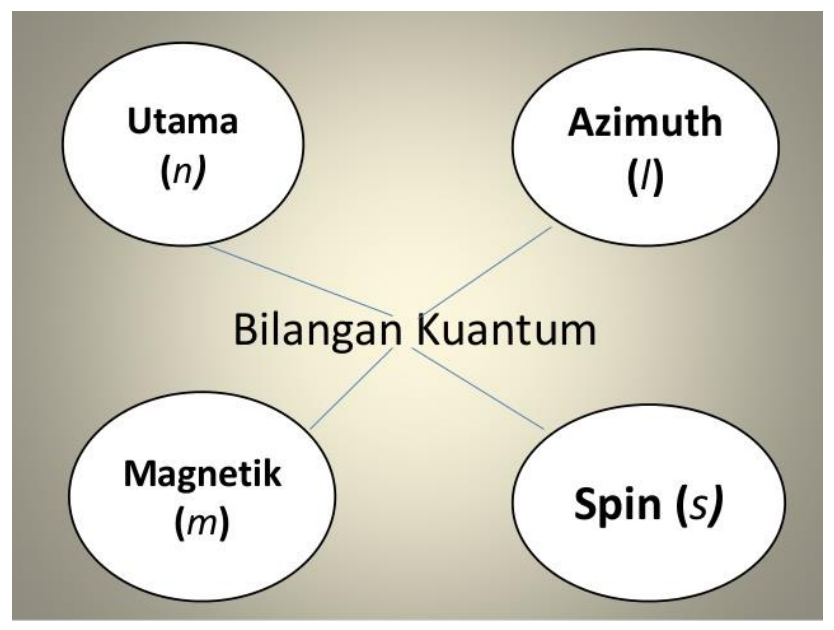

Gambar 1.14 Kombinasi Bilangan Kuantum 


\subsubsection{Orbital s}

Orbital $\mathrm{s}$ adalah orbital dengan $\mathrm{I}=0$ berbentuk bola dengan inti atom pada bagian tengah. Oleh karena bola hanya memiliki satu orientasi, semua orbital s hanya memiliki satu nilai $\mathrm{ml}$, yaitu $\mathrm{ml}=0$. Orbital 1s memiliki densitas (kerapatan) elektron tertinggi pada bagian inti atom dan kemudian densitas semakin menurun perlahan-lahan setelah menjauh dari inti atom. Orbital $2 \mathrm{~s}$ memiliki dua daerah dengan densitas elektron tinggi. Di antara kedua daerah tersebut terdapat simpul bola, di mana probabilitas menemukan elektron pada daerah tersebut menurun hingga nol $(\psi 2=0)$. Pada orbital 3s, terdapat tiga daerah dengan densitas elektron tinggi dan dua simpul. Pola bertambahnya simpul orbital $s$ ini masih terus berlanjut dengan orbital $4 \mathrm{~s}, 5 \mathrm{~s}$, dan seterusnya.[1]

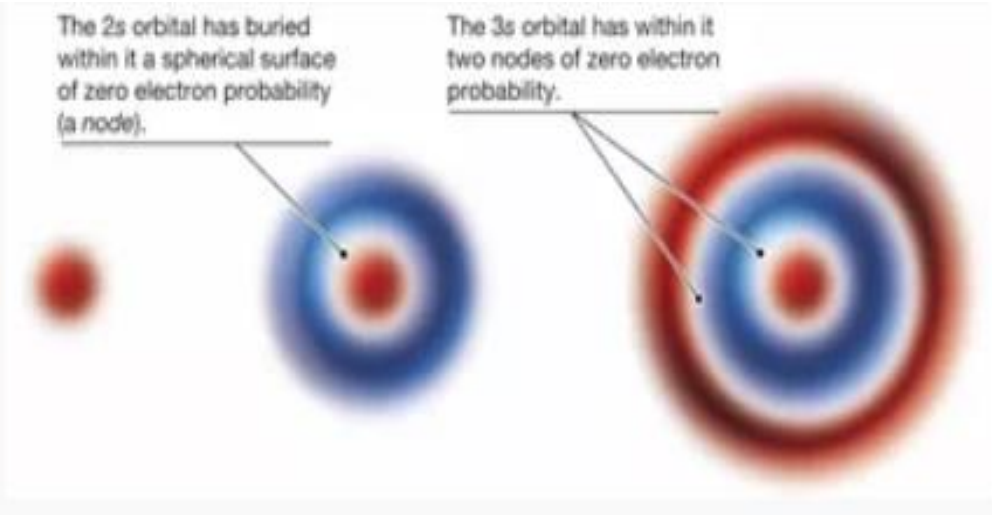

Gambar 1.15. Representasi Orbital 1s, 2s dan 3s 


\subsubsection{Orbital $p$}

Orbital $p$ adalah orbital dengan I = 1 berbentuk seperti balon terpilin dengan dua cuping. Kedua cuping terletak pada dua sisi inti atom yang saling bersebrangan. Inti atom terletak pada bidang simpul orbital $p$, yakni di antara dua cuping yang masing-masing memiliki densitas elektron tinggi. Orbital $p$ memiliki tiga jenis orientasi ruang, px, py, dan $\mathrm{pz}$, sebagaimana terdapat tiga nilai $\mathrm{ml}$ yang mungkin, yaitu $-1,0$, atau +1 . Ketiga orbital $p$ tersebut terletak saling tegak lurus pada sumbu $x, y$, dan $z$ koordinat Kartesius dengan bentuk, ukuran, dan energi yang sama.
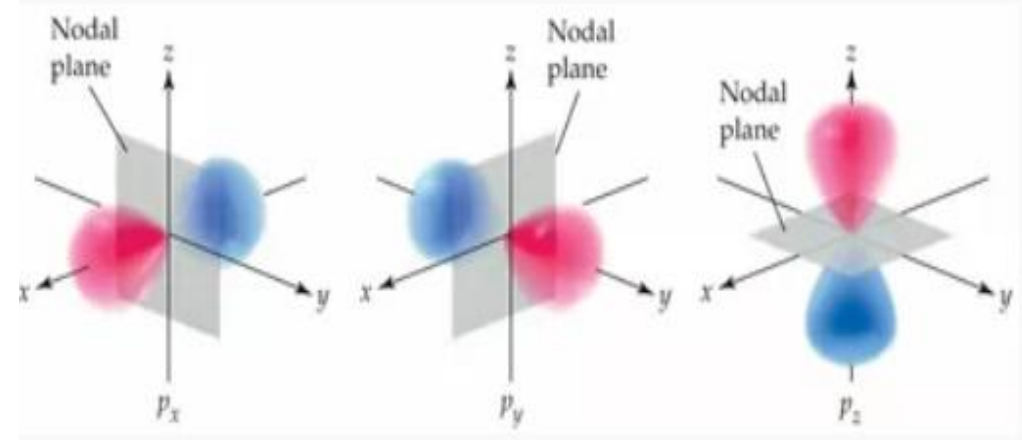

Gambar 1.16 Representasi orbital 2p: px, py, dan pz

\subsubsection{Orbital d}

Orbital $d$ adalah orbital dengan $I=2$. Orbital $d$ memiliki lima jenis orientasi, sebagaimana terdapat lima nilai $\mathrm{ml}$ yang mungkin, yaitu $-2,-1,0,+1$, atau +2 . Empat dari lima orbital $d$, antara lain $d_{x y}, d_{x z}$ $d_{y z}$, dan $d_{x}{ }^{2}-y^{2}$, memiliki empat cuping seperti bentuk daun 
semanggi. Orbital $d$ kelima, $d_{z}{ }^{2}$, memiliki dua cuping utama pada sumbu z dan satu bagian berbentuk donat pada bagian tengah.
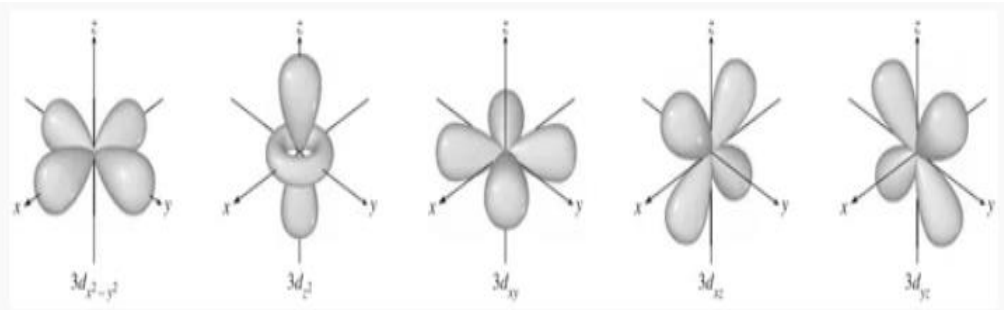

Gambar 1.17 Representasi Orbital 3d: Dz2, Dx2-Y2, Dxy, Dxz, Dan Dyz

\subsubsection{Orbital $f$}

Orbital $f$ adalah orbital dengan $I=3$. Orbital $f$ memiliki tujuh jenis orientasi, sebagaimana terdapat tujuh nilai ml yang mungkin $(2 \mid+1$ $=7)$. Ketujuh orbital $f$ memiliki bentuk yang kompleks dengan beberapa cuping.

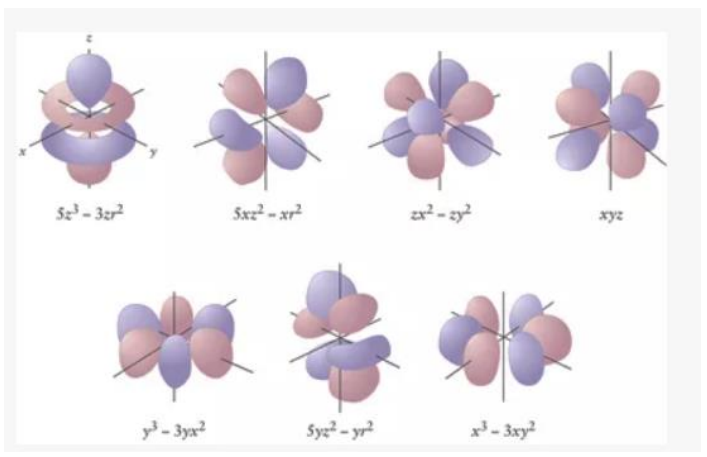

Gambar 1.28 Representasi Ketujuh Orbital $4 f$ 


\subsection{Konfigurasi Elektron.}

Setelah memahami hubungan keberadaan elektron dalam atom dengan orbital pada teori atom mekanika kuantum, berikut akan dibahas konfigurasi elektron, yaitu penyusunan elektronelektron dalam orbital-orbital pada kulit-kulit atom multi elektron. Aturan-aturan dalam penentuan konfigurasi elektron berdasarkan orbital, antara lain:

1. Asas Aufbau: Elektron menempati orbital-orbital dimulai dari tingkat energi yang terendah, dimulai dari $1 s, 2 s, 2 p$, dan seterusnya seperti urutan subkulit yang terlihat pada gambar berikut.

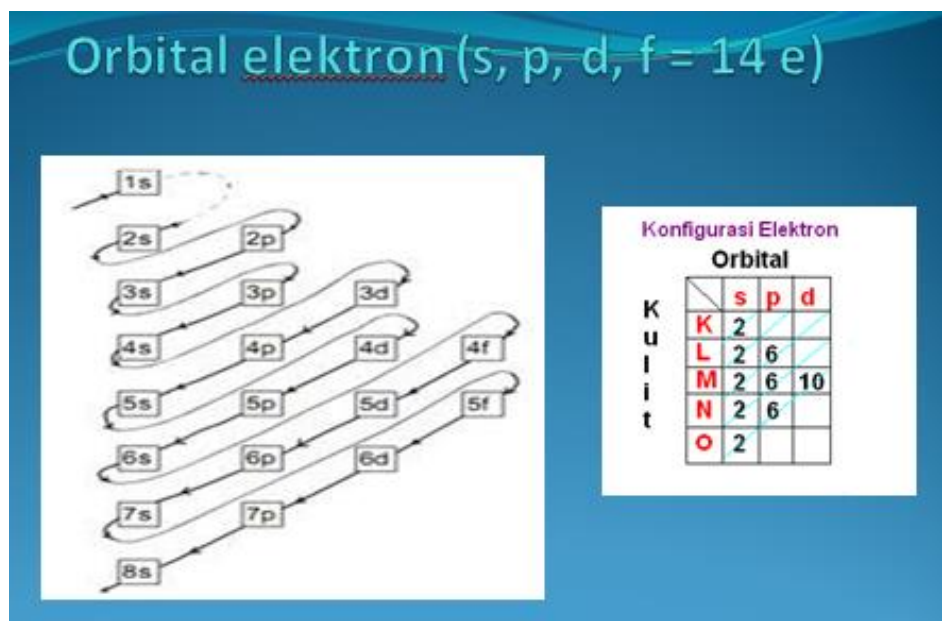

Gambar 1.19 Tingkat Orbital Elektron

2. Asas larangan Pauli: Tidak ada dua elektron dalam satu atom yang memiliki keempat bilangan kuantum yang sama. 
Setiap orbital maksimum diisi oleh 2 elektron yang memiliki spin yang berlawanan ( $\mathrm{ms}=+1 / 2$ dan $\mathrm{ms}=-1 / 2)$.

3. Kaidah Hund: Jika ada orbital dengan tingkat energi yang sama, konfigurasi elektron dengan energi terendah adalah dengan jumlah elektron tak berpasangan dengan spin paralel yang paling banyak.

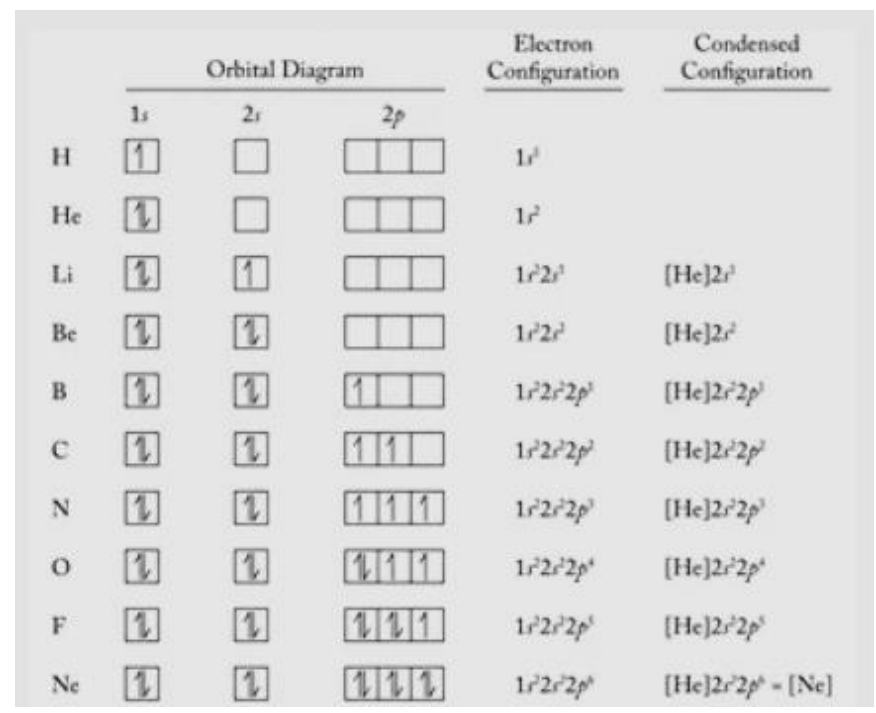

Gambar 1.20 Konfigurasi Elektron

Berdasarkan eksperimen, terdapat anomali konfigurasi elektron dari aturan-aturan di atas. Subkulit d memiliki kecenderungan untuk terisi setengah penuh atau terisi penuh. Contohnya, konfigurasi elektron 24Cr: [Ar] 4s1 3d5 lebih stabil dibanding [Ar] 4s2 3d4; dan 29Cu: [Ar] 4s1 3d10 lebih stabil dibanding [Ar] 4s2 3d9.[4] 
Konfigurasi elektron untuk ion monoatomik (seperti $\mathrm{Na}+, \mathrm{K}+$, $\mathrm{Ca} 2+, \mathrm{S2}-, \mathrm{Br}-$ ) dapat ditentukan dari konfigurasi elektron atom netralnya terlebih dahulu. Pada kation (ion bermuatan positif) monoatomik $\mathrm{Ax}+$ yang bermuatan $\mathrm{x}+$, sebanyak $\mathrm{x}$ elektron dilepas (dikurangi) dari kulit elektron terluar atom netral A. Pada anion (ion bermuatan negatif) monoatomik By- yang bermuatan y-, sebanyak y elektron ditangkap (ditambahkan) pada orbital level energi terendah yang masih belum penuh oleh elektron.

\section{Contoh Soal Bilangan Kuantum :}

Tentukan konfigurasi elektron dan diagram elektron dari atom unsur dan ion monoatomik berikut.
a. ${ }_{27} \mathrm{Co}$
b. ${ }_{32} \mathrm{Ge}$
C. ${ }_{20} \mathrm{Mg} 2+$
d. ${ }_{26} \mathrm{Fe} 3+$
e. ${ }_{8} \mathrm{O} 2-$

Pembahasan:

a. ${ }_{27} \mathrm{Co:} 1 \mathrm{~s} 2 \mathrm{2s} 2 \mathrm{2p} 63 \mathrm{~s} 23 \mathrm{p} 64 \mathrm{~s} 23 \mathrm{~d} 7$ atau [Ar] $4 \mathrm{~s} 23 \mathrm{~d} 7$

27Co

b. ${ }_{32} \mathrm{Ge}: 1 \mathrm{~s} 2$ 2s2 2p6 3s2 3p6 4s2 3d10 4p2 atau [Ar] 4s2 3d10 4p2 
${ }_{32} \mathrm{Ge}$

C. $20 \mathrm{Mg}: 1 \mathrm{~s} 2$ 2s2 2p6 3s2 3p6 4s2 atau [Ar] 4s2

20Mg2+: 1s2 2s2 2p6 3s2 3p6 atau [Ar] (sebanyak 2 elektron dikurangi dari kulit terluar: $4 \mathrm{~s} 2-2$ )

${ }_{20} \mathrm{mg} 2+$

d. ${ }_{26} \mathrm{Fe}: 1 \mathrm{~s} 2 \mathrm{2s} 2 \mathrm{2p} 63 \mathrm{~s} 2 \mathrm{pp} 64 \mathrm{~s} 23 \mathrm{~d} 6$ atau [Ar] $4 \mathrm{~s} 2 \mathrm{dd} 6$

${ }_{26} \mathrm{Fe} 3+:$ 1s2 2s2 2p6 3s2 3p6 3d5 atau [Ar] 3d5 (sebanyak 3 elektron dikurangi dari kulit terluar: $4 s 2-23 d 6-1)$

${ }_{26} \mathrm{fe} 3+$

e. ${ }_{8} \mathrm{O}: 1 s 2 \mathrm{~s} 22 \mathrm{p} 4$ atau [He] $2 \mathrm{~s} 22 \mathrm{p} 4$

${ }_{8} \mathrm{O} 2-:$ 1s2 2s2 2p6 atau [He] 2s2 2p6 atau [Ne] (sebanyak 2 elektron ditambahkan: 2s2 2p4+2)

\subsection{Pita Energy}

Pada pembahsan diatas diketahui bahwa atom trediri dari inti dan elektron - elektron, dimana inti terdiri dari neutron dan proton. Eelktron ini berada pada kulit atom memiliki tingkatan energi masing - masing, sehingga hal ini akan menyebabkan elektron itu berada pada lintasan nya. Demikian juga terjadi pada kristal. Kristal memiliki tingkat energi yang dapat digambarkan dengan cara yang sama dengan atom tunggal. Interaksi antar atom pada kristal hanya 
terjadi pada elektron di kulit terluar (elektron valensi), sehingga tingkat energi untuk elektron pada kulit bagian dalam tidak berubah.

Suatu tingkatan energi tidak boleh terdapat lebih dari satu elektron pada keadaan yang sama, hal ini dijelaskan pada azas Pauli. Apabila terdapat lebih dari satu elektron pada keadaan yang sama, akan terjadi pergeseran tingkat energi, sehingga tidak pernah terjadi tingkat-tingkat energi yang bertindihan. Kumpulan garis pada tingkat energiyang sama akan saling berhimpit dan membentuk suatu pita yang disebut sebagai pita energi.

Pada sebuah atom tunggal elektron-elektronnya hanya boleh menempati tingkat-tingkat energi tertentu seperti yang ditunjukkan oleh gambar 1.31. Sedangkan untuk kristal yang memiliki atom yang tersusun secara periodik dan teratur sehingga atom-atomnya saling berdekatan. Hal inilah yang menyebabkan elektro-elektron yang berada pada kulit terluar (elektron valensi) akan saling berinteraksi sehingga tingkat-tingkat energinya akan saling berhimpit dan dianggap membentuk suatu pita energiseperti pada gambar $1(b)[1]$.

\section{JENIS-JENIS PITA ENERGI}

Secara umum, pita energi ini akan terbagi menjadi 2 (dua) daerah besar, yaitu daerahpita valensi (Valence Band) dan pita konduksi (Conduction Band). Atom-atom padadaerah pita valensi terikat sangat erat dengan inti atom, sedangkan atom-atom padadeerah pita konduksi mudah sekali terlepas dari inti atom. Pada umumnya, antara pita valensi dan pita konduksi memiliki jarak tertentu yangdikenal dengan istilah celah energi. Berdasarkan celah energi inilah sifat-sifatmaterial dapat dibedakan. Elektronelektron tidak diperbolehkan menempati celah-celah energi ini. 
Besarnya energi yang diperlukan untuk memindahkan elektron daripita valensi ke pita konduksi adalah sebesar energi pada pita terlarang[5].

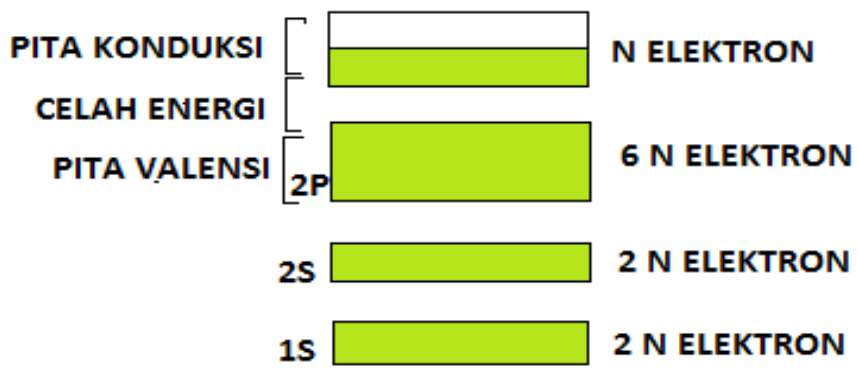

PITA-PITA ENERGI NATRIUM

Gambar 1.21 Pita Energi Natrium

Berdasarkan celah energinya suatu material dibagi menjadi tiga macam, yaitu :

\section{Konduktor}

Bahan yang bersifat konduktor ini biasaya berupa material logam dimana energygap (celah energi) nya saling tumpang tindih (overlap) sehingga atom-atom daripita valensi ini sangat mudah berpindah ke pita konduksi. Hal inilah yangmenyebabkan logam memiliki sifat konduktif (dapat menghantarkan arus listrik).,dimana konduktivitas listriknya ( ) $\geq 10 \sigma 5 /$ m. Gambar 1.32, mengilustrasikan pita energi dan celah energi pada konduktor. 
Significant leap required for an electron to move to the next higher level

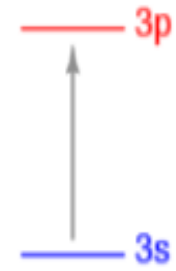

Single atom
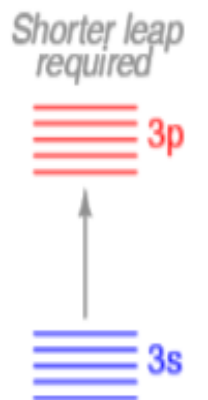

Five atoms in close proximity

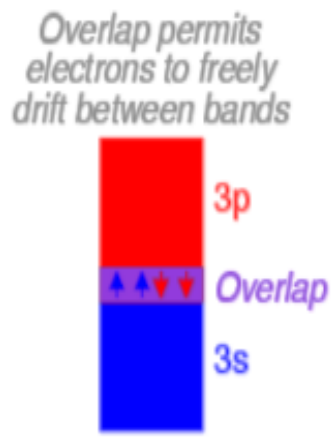

Multitudes of atoms in close proximity

Gambar 1.22 Pita Energi

2. Isolator

Untuk material-material non-logam ini biasanya memiliki celah energy yang berjauhan sehingga atom-atom sulit untuk bergerak kearah pita konduksi. Sehingga material-material jenis ini memiliki sifat sulit untuk untukmenghantarkan listrik atau isolator, dimana untuk bahan/material jenis ini konduktivitasnya ( ) 10б-5/m. Berikut adalah gambar pita dan celah energi untuk $\Omega$ material isolator Gambar 1.33

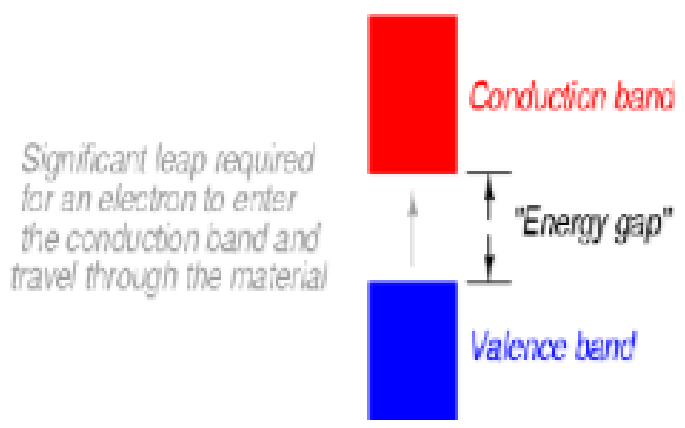

Gambar 1.23 Pita Energi Konduktor 


\section{Semi Konduktor}

Semikonduktor Namun terdapat beberapa bahan/material yang memiliki celah energi yangberdekatan. Oleh karena itu, pada kondisi normal atom-atom sulit bergerak kedaerah pita konduksi sehingga bersifat isolator. Tetapi jika diberi sedikittambahan energi, atom-atom tersebut dapat bergerak ke daerah pita konduksisehingga menjadi bersifat konduktor. Untuk material/bahan jenis ini memiliki konduktifitas listrik sebesar 10$5 / \mathrm{m} \leq \geq 10 \Omega \sigma 5 / \mathrm{m}$. Karena sifatnya yang demikian, bahan/material tersebut dikenal sebagai semikonduktor. Gambar 1.34, menunjukkan ilustrasi dari pita energi dan celah energi yang dimiliki oleh bahan semikonduktor.

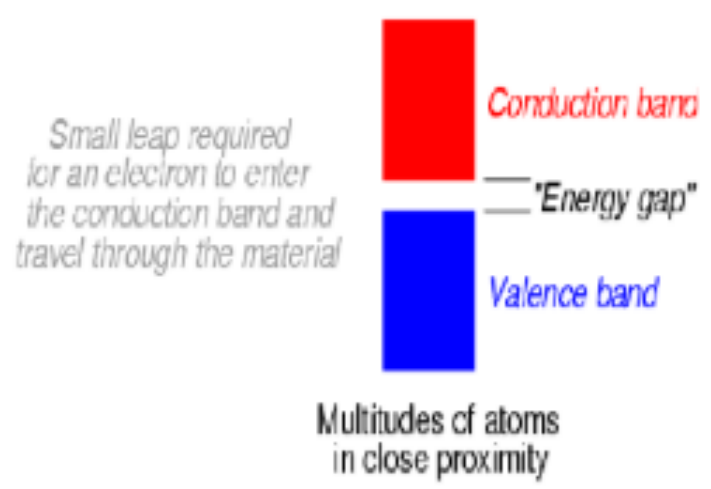

Gambar 1.24 Pita Energi Semi Konduktor

Material-material yang telah disebutkan sebelumnya, memiliki daya hantar(konduktifitas) listrik yang berbeda-beda. Untuk dapat menerangkan sifat dayahantar listrik zat padat 
diperlukan sebuah model. Model yang dikembangkan adalahmodel elektron bebas terkuantisasi, namun pada model ini tidak dapat menjelaskanrentang nilai konduktivitas listrik dari zat padat yang lebar. Pada model ini potensialdari gugus ion diabaikan $(V=0)$. Model yang kedua adalah model pita energi, dimana model ini dapat menjelaskanrentang nilai konduktivitas listrik dari zat padat yang lebar. Pada model ini potensialdari gugus ion tidak diabaikan atau terdapat potensial yang berkala pada suatu zat padat.

1. Model atom apakah yang sampai saat in masih dipergunakan ?

2. Bagaimana kah struktur dari Pita valensi konduktor?

3. Bagaimana kah struktur dari Pita valensi Isolator?

4. Bagaimana kah struktur dari Pita valensi Semi konduktor?

\section{BAB II}




\section{Benda dan Bahan Listrik}

Tujuan Instruksional :

Setelah mempelajari Bab ini, di harapkan pembaca dapat memahami :

1. Bagaimana Mengetahui Bahan Listrik

2. Pengelompokan Bahan bahan Listriknya

Benda dan Bahan listrik ini adalah segala jenis benda atau bahan yang dapat digunakan dalam peralatan, perlengkapan dan alat bantu yang berhubungan dengan secara langsung atau tidak langsung dengan listrik. Pengetahun benda dan bahan listrik ini sangat diperlukan untuk memahami bagaimana sifat dan karakteristik benda dan bahan listrik tersebut.

\subsection{Pentingnya Pengetahuan Tentang Bahan Listrik}

Mengetahui tentang bahan listrik ini sangat diperlukan agar supaya dapat diketahui jenis dan sifat dari bahan tersebut, agar supaya dapat memperlakukan atau memanfaatkan bahan tersebut dengan sebaik baiknyaa dan mengetahui batasan aman atau bahaya suatu bahan.

\subsection{Pengelompokan Bahan Listrik}

Secara umum bahan - bahan listrik dapat dikelompokkan menjadi beberapa jenis bahan sebagai berikut :

1. Bahan tambang dan Bahan Non Tambang.

2. Bahan Renewable dan unrenewable.

3. Bahan logam dan non logam.

4. Bahan organik dan bahan sintetis. 
Sedangkan bahan - bahan listrik dapat dikelompokkan menjadi :

1. Bahan penghantar (Konduktor).

2. Bahan Penyekat (Isolator).

3. Bahan Setengah konduktor (Semi konduktor).

4. Bahan Magnet.

5. Bahan Super Konduktor.

6. Bahan Serat optik.

7. Bahan Khusus.
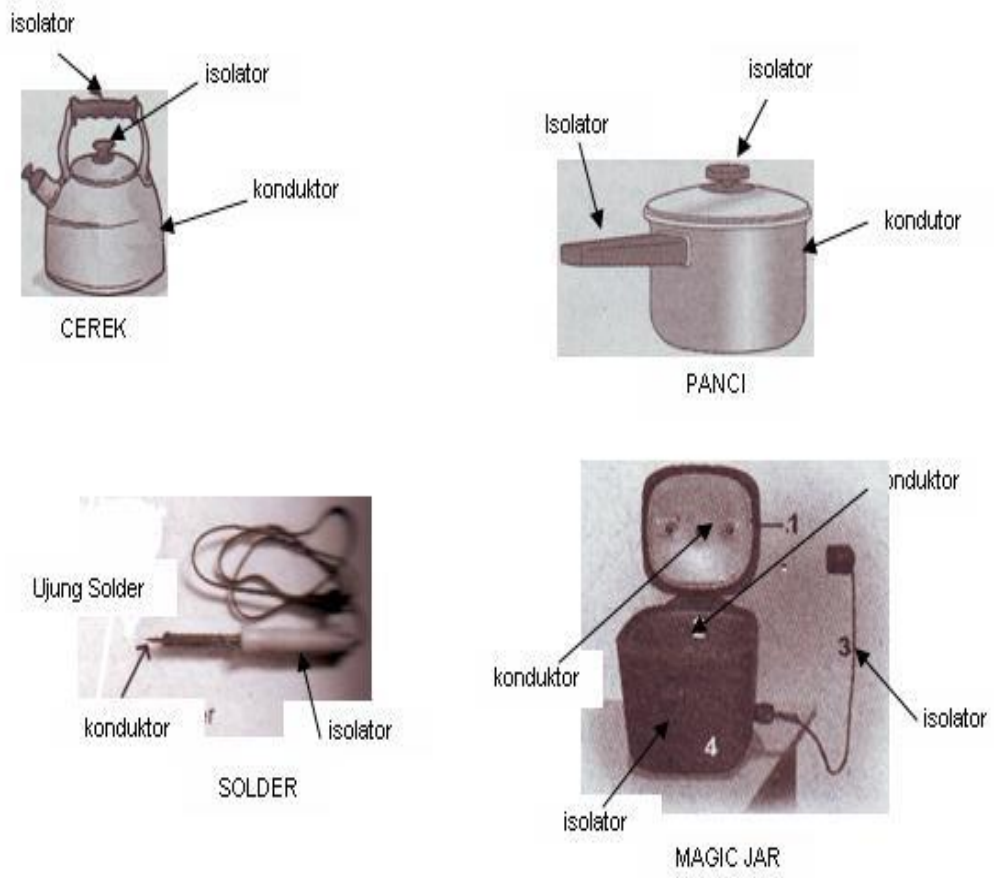

Gambar 2.1 Material Yang Terdiri Dari Bahan - Bahan Listrik 
Adapun penjelasan dari masing - masing bahan Isitrik itu adalah sebagai berikut :

\subsubsection{Bahan Penghantar (Konduktor).}

Konduktor adalah bahan yang menghantarkan listrik dengan mudah. Bahan ini mempunyai daya hantar listrik (Electrical Conductivity) yang besar dan tahanan listrik (Electrical Resistance) kecil. Bahan penghantar listrik berfungsi untuk mengalirkan arus listrik. Konduktor adalah jenis-jenis bahan yang dapat menghantarkan energi listrik melalui zat padat, cair, dan gas dengan sangat baik[1].

\section{A. Karakteristik konduktor}

Karakteristik Mekanik yang menunjukkan keadaan fisik dari konduktor yang menyatakan kekuatan tarik dari pada konduktor (dari SPLN 41-8:1981, untuk konduktor $70 \mathrm{~mm} 2$ berselubung AAAC$S$ pada suhu sekitar 30 derajat $C$, maka kemampuan maksimal dari konduktor untuk menghantar arus adalah 275 A).

Karakteristik Listrik, yang menunjukkan kemampuan dari konduktor terhadap arus listrik yang melewatinya (dari SPLN 41-10 : 1991, untuk konduktor $70 \mathrm{~mm} 2$ berselubung AAAC-S pada suhu sekitar 30 derajat $C$, maka kemampuan maksimum dari konduktor untuk menghantar arus adalah $275 \mathrm{~A}$ ). 


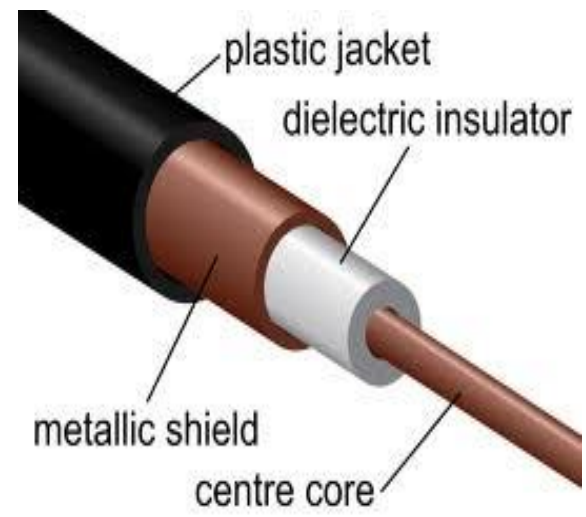

Gambar 2.2 Salah Satu Contoh Konduktor

B. Sifat-sifat konduktor

Konduktor memiliki sifat-sifat bahan yang sangat penting, yaitu sebagai berikut[6] :

\section{a. Daya Hantar Panas}

Sifat ini merupakan kondisi yang menyatakan jumlah panas yang melewati lapisan bahan dalam kurun waktu tertentu. Bahan-bahan yang memiliki daya hantar panas yang tinggi adalah jenis-jenis logam. Dan daya hantar panas tersebut dinyatakan dalam bentuk satuan $\mathrm{kkal} / \mathrm{jam}{ }^{\circ} \mathrm{C}$.

\section{b. Daya Elektro-Motoric Termo}

Arus listrik pada rangkaian listrik selalu mengalami perubahan pada daya elektro-motoric termo jika terjadi perubahan kondisi suhu. Sifat ini memiliki peranan sangat penting pada dua jenis logam berbeda yang dipasang pada dua titik kontak. Daya elektro-motoric termo merupakan daya electro-motoric yang digunakan pada 
kondisi suhu yang berbeda. Perbedaan temperatur suhu tersebut berbanding lurus dengan kedua jenis bahan yang dihasilkan, serta adanya perbedaan yang jauh pada tegangan listrik.

\section{c. Konduktivitas listrik}

Menyatakan kemudahan suatu material untuk meneruskan arus listrik. Satuan konduktivitas adalah (ohm meter). Konduktivitas merupakan sifat listrik yang diperlukan dalam berbagai pemakaian sebagai penghantar tenaga listrik dan mempunyai rentang harga yang sangat luas. Logam atau material yang merupakan penghantar listrik yang baik, memiliki konduktivitas listrik dengan orde 107 (ohm.meter) -1 dan sebaliknya material isolator memiliki konduktivitas yang sangat rendah, yaitu antara 10-10 sampai dengan 10-20 (ohm.m)-1. Diantara kedua sifat ekstrim tersebut, ada material semi konduktor yang konduktivitasnya berkisar antara 10-6 sampai dengan 10-4 (ohm.m)-1. Berbeda pada kabel tegangan rendah, pada kabel tegangan menengah untuk pemenuhan fungsi penghantar dan pengaman terhadap penggunaan, ketiga jenis atau sifat konduktivitas tersebut diatas digunakan semuanya.

$$
R=\rho(I / A)
$$

Keterangan :

$\mathrm{R}=$ hambatan $(\Omega)$

$\rho=$ hambatan jenis $(\Omega . \mathrm{mm} 2 / \mathrm{m})$

I = panjang penghantar (meter)

$A=$ luas penampang kawat $(\mathrm{mm} 2)$ 
Perak ( Ag ) ......................... 6,8 6 × $10^{7}$

Tembaga ( $\mathrm{Cu})$..................... 6,0 $010^{7}$

Emas $(\mathrm{Au})$........................ 4,3 $410^{7}$

Alumunium ( Ac ) ................. 3,8 8 10 $10^{7}$

Kuningan ( $70 \% \mathrm{Cu}-30 \% \mathrm{Zn}) \ldots 1,6 \times 10^{7}$

Besi ( Fe ) ...............................1,0 x 10

Baja karbon ( Ffe - C ) ............ 0,6 x 10

Baja tahan karat ( Ffe $-\mathrm{Cr}$ ) ... 0,2 x 10

d. Kekuatan Tegangan Tarik

Sifat ini sangat penting digunakan saat terjadi pendistribusian tegangan tinggi.

e. Koefisien Suhu Tahanan

Seperti yang telah kita ketahui bahwa bahan akan memuai ketika berada pada suhu tinggi, dan akan menyusut jika temperatur menurun. Bahan penghantar yang paling sering digunakan adalah tembaga, karena paling mudah didapatkan serta dengan penawaran harga yang murah.

Jenis-jenis bahan Konduktor

Penghantar memiliki peranan untuk menyalurkan aliran listrik dari satu lokasi ke lokasi lainnya. Beberapa bahan konduktor terbaik adalah sebagai berikut :

a. Alumunium

Aluminium ialah unsur kimia. Lambang aluminium ialah $\mathrm{Al}$, dan nomor atomnya 13 . Aluminium ialah logam paling berlimpah. Titik didih $2792 \mathrm{~K}\left(2519^{\circ} \mathrm{C}, 4566^{\circ} \mathrm{F}\right)$ 


\section{b. Perak}

Perak adalah suatu unsur kimia dalam tabel periodik yang memiliki lambang Ag dan nomor atom 47. Lambangnya berasal dari bahasa Latin Argentum. Sebuah logam transisi lunak, putih, mengkilap, perak memiliki konduktivitas listrik dan panas tertinggi di seluruh logam dan terdapat di mineral dan dalam bentuk bebas. Logam ini digunakan dalam koin, perhiasan, peralatan meja, dan fotografi. Perak termasuk logam mulia seperti emas. Titik didih 2435 K (2162 $\left.{ }^{\circ} \mathrm{C}, 3924^{\circ} \mathrm{F}\right)$.

\section{c. Emas}

Emas adalah unsur kimia dlm tabel periodik yang memiliki simbol $\mathrm{Au}$ (bahasa Latin: 'aurum') dan nomor atom 79. Sebuah logam transisi (trivalen dan univalen) yang lembek, mengkilap, kuning, berat, "malleable", dan "ductile". Emas tidak bereaksi dengan zat kimia lainnya tapi terserang oleh klorin, fluorin dan aqua regia. Logam ini banyak terdapat di nugget emas atau serbuk di bebatuan dan di deposit alluvial dan salah satu logam coinage. Kode ISOnya adalah XAU. Emas melebur dalam bentuk cair pada suhu sekitar 1000 derajat celcius.Titik didih $3129 \mathrm{~K}\left(2856^{\circ} \mathrm{C}, 5173{ }^{\circ} \mathrm{F}\right)$.

\section{d. Seng}

Seng (bahasa Belanda: zink) adalah unsur kimia dengan lambang kimia Zn, nomor atom 30, dan massa atom relatif 65,39. Ia merupakan unsur pertama golongan 12 pada tabel periodik. Beberapa aspek kimiawi seng mirip dengan magnesium. Hal ini dikarenakan ion kedua unsur ini berukuran hampir sama. Selain itu, keduanya juga memiliki keadaan oksidasi +2 . Seng merupakan unsur paling melimpah ke-24 di kerak Bumi dan memiliki lima isotop 
stabil. Bijih seng yang paling banyak ditambang adalah sfalerit (seng sulfida).Titik didih $1180 \mathrm{~K}\left(907^{\circ} \mathrm{C}, 1665^{\circ} \mathrm{F}\right)$

\section{e. Tembaga}

Tembaga adalah suatu unsur kimia dalam tabel periodik yang memiliki lambang $\mathrm{Cu}$ dan nomor atom 29. Lambangnya berasal dari bahasa Latin Cuprum. Tembaga merupakan konduktor panas dan listrik yang baik.Selain itu unsur ini memiliki korosi yang cepat sekali. Tembaga murni sifatnya halus dan lunak, dengan permukaan berwarna jingga kemerahan. Tembaga dicampurkan dengan timah untuk membuat perunggu. Logam ini dan aloinya telah digunakan selama empat hari. Di era Roma, tembaga umumnya ditambang di Siprus, yang juga asal dari nama logam ini (cyprium, logam Siprus), nantinya disingkat jadi cuprum). Ikatan dari logam ini biasanya dinamai dengan tembaga(II). Ion Tembaga(II) dapat berlarut ke dalam air, dimana dimana dimana fungsi mereka dalam konsentrasi tinggi adalah sebagai agen anti bakteri, fungisiddol, dan bahan tambahan kayu. Dalam konsentrasi tinggi maka tembaga akan bersifat racun, tapi dalam jumlah sedikit tembaga merupakan nutrien yang penting bagi kehidupan manusia dan tanaman tingkat rendah. Di dalam tubuh, tembaga biasanya ditemukan di bagian hati, otak, usus, jantung, dan ginjal.Titik didih $2835 \mathrm{~K}\left(2562{ }^{\circ} \mathrm{C}, 4643\right.$ $\left.{ }^{\circ} \mathrm{F}\right)$.

\section{f. Platina}

Platina adalah suatu unsur kimia dalam tabel periodik yang memiliki lambang Pt dan nomor atom 78. Sebuah logam transisi yang berat, "malleable", "ductile", berharga, berwarna putih-keabuan. Platinum tahan karat dan terdapa dalam beberapa bijih nikel dan copper. Platinum digunakan dalam perhiasan, peralatan 
laboratorium, gigi, dan peralatan kontrol emisi mobil.Titik didih $4098 \mathrm{~K}\left(3825^{\circ} \mathrm{C}, 6917^{\circ} \mathrm{F}\right)$.

\section{g. Besi}

digunakan untuk kehidupan manusia sehari-hari. Dalam tabel periodik, besi mempunyai simbol Fe dan nomor atom 26. Besi juga mempunyai nilai ekonomis yang Besi adalah logam yang berasal dari bijih besi (tambang) yang banyak tinggi.Titik didih $3134 \mathrm{~K}$ (2861 $\left.{ }^{\circ} \mathrm{C}, 5182^{\circ} \mathrm{F}\right)$.

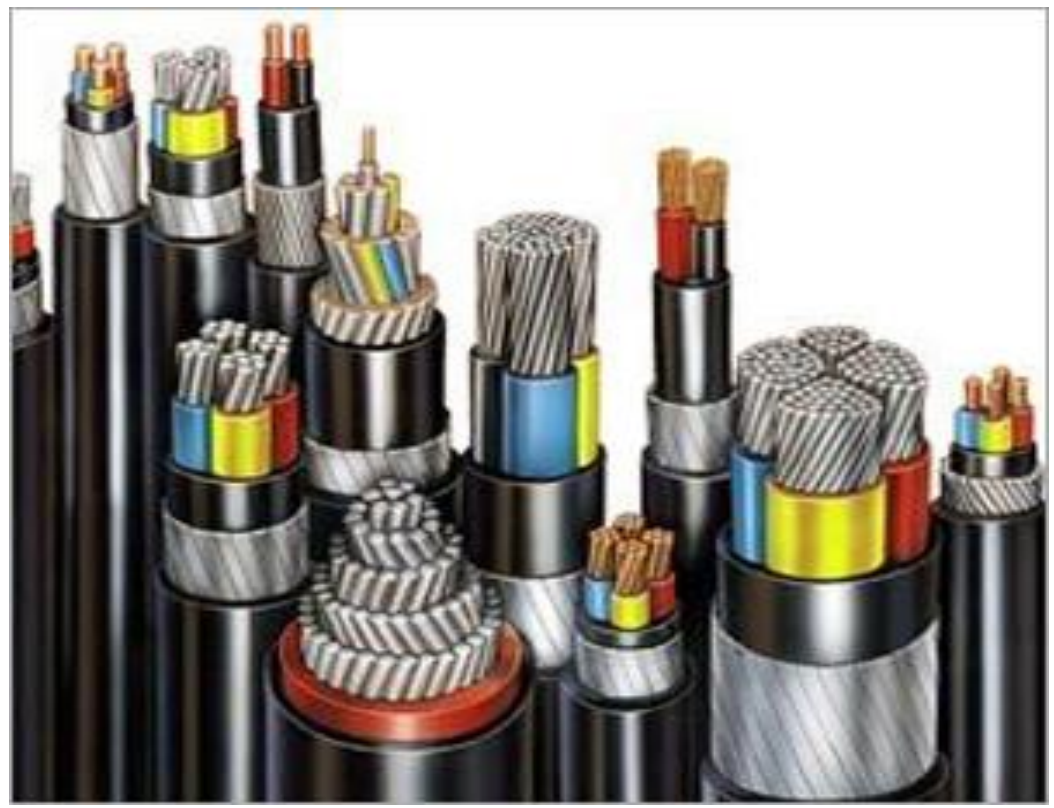

Gambar 2.3 Tipe Kabel Yang Sering Dijumpai Di Lapangan 


\subsubsection{Bahan Penyekat (Isolator).}

\section{a. Sifat-Sifat Bahan Penyekat}

Bahan penyekat digunakan untuk memisahkan bagian-bagian yang bertegangan. Untuk itu pemakaian bahan penyekat perlu mempertimbangkan sifat kelistrikanya. Di samping itu juga perlu mempertimbangkan sifat termal, sifat mekanis, dan sifat kimia.

Sifat kelistrikan mencakup resistivitas, permitivitas, dan kerugian dielektrik. Penyekat membutuhkan bahan yang mempunyai resistivitas yang besar agar arus yang bocor sekecil mungkin (dapat diabaikan). Yang perlu diperhatikan di sini adalah bahwa bahan isolasi yang higroskopis hendaknya dipertimbangkan penggunaannya pada tempat-tempat yang lembab karena resistivitasnya akan turun. Resistivitas juga akan turun jika tegangan yang diberikan naik.

Besarnya kapasitansi bahan isolasi yang berfungsi sebagai dielektrik ditentukan oleh permitivitasnya, di samping jarak dan luas permukaannya. Besarnya permitivitas udara adalah 1,00059, sedangakan untuk zat padat dan zat cair selalu lebih besar dari itu. Apabila bahan isolasi diberi tegangan bolak-balik maka akan terdapat energi yang diserap oleh bahan tersebut. Besarnya kerugian energi yang diserap bahan isolasi tersebut berbanding lurus dengan tegangan, frekuensi, kapasitansi, dan sudut kerugian dielektrik. Sudut tersebut terletak antara arus kapasitif dan arus total $(I c+I r)[6]$.

Suhu juga berpengaruh terhadap kekuatan mekanis, kekerasan, viskositas, ketahanan terhadap pengaruh kimia dan sebagainya. Bahan isolasi dapat rusak diakibatkan oleh panas pada kurun waktu tertentu. Waktu tersebut disebut umur panas bahan isolasi. Sedangakan kemampuan bahan menahan suhu tertentu tanpa terjadi kerusakan disebut ketahanan panas. Menurut IEC 
(International Electrotechnical Commission) didasarkan atas batas suhu kerja bahan, bahan isolasi yang digunakan pada suhu di bawah nol (missal pada pesawat terbang, pegunungan) perlu juga diperhitungkan karena pada suhu di bawah nol bahan isolasi akan menjadi keras dan regas. Pada mesin-mesin listrik, kenaikan suhu pada penghantar dipengaruhi oleh resistansi panas bahan isolasi. Bahan isolasi tersebut hendaknya mampu meneruskan panas yang didesipasikan oleh penghantar atau rangkaian magnetik ke udara sekelilingnya.

Kemampuan larut bahan isolasi, resistansi kimia, higroskopis, permeabilitas uap, pengaruh tropis, dan resistansi radio aktif perlu dipertimbangkan pada penggunaan tertentu. Kemampuan larut diperlukan dalam menentukan macam bahan pelarut untuk suatu bahan dan dalam menguji kemampuan bahan isolasi terhadap cairan tertentu selama diimpregnasi atau dalam pemakaian. Kemampuan larut bahan padat dapat dihitung berdasarkan banyaknya bagian permukaan bahan yang dapat larut setiap satuan waktu jika diberi bahan pelarut. Umumnya kemampuan larut bahan akan bertambah jika suhu dinaikkan.

Ketahanan terhadap korosi akibat gas, air, asam, basa, dan garam bahan isolasi juga nervariasi antara satu pemakaian bahan isolasi di daerah yang konsentrasi kimianya aktif, instalasi tegangan tinggi, dan suhu di atas normal. Uap air dapat memperkecil daya isolasi bahan. Karena bahan isolasi juga mempunyai sifat higroskopis maka selama penyimpanan atau pemakaian diusahakan agar tidak terjadi penyerapan uap air oleh bahan isolasi, dengan memberikan bahan penyerap uap air, yaitu senyawa P2O5 atau $\mathrm{CaC12}$. Bahan yang molekulnya berisi kelompok hidroksil $(\mathrm{OH})$ higrokopisitasnya relative besar dibanding bahan parafin dan polietilin yang tidak dapat menyerap uap air. Bahan isolasi 
hendaknya juga mempunyai permeabilitas uap (kemampuan untuk dilewati uap) yang besar, khususnya bagi bahan yang digunakan untuk isolasi kabel dan rumah kapasitor. Di daerah tropis basah dimungkinkan tumbuhnya jamur dan serangga. Suhu yang tinggi disertai kelembaban dalam waktu lama dapat menyebabkan turunnya kemampuan isolasi. Oleh karena bahan isolasi hendaknya dipisi bahan anti jamur (paranitro phenol, dan pentha chloro phenol)[7].

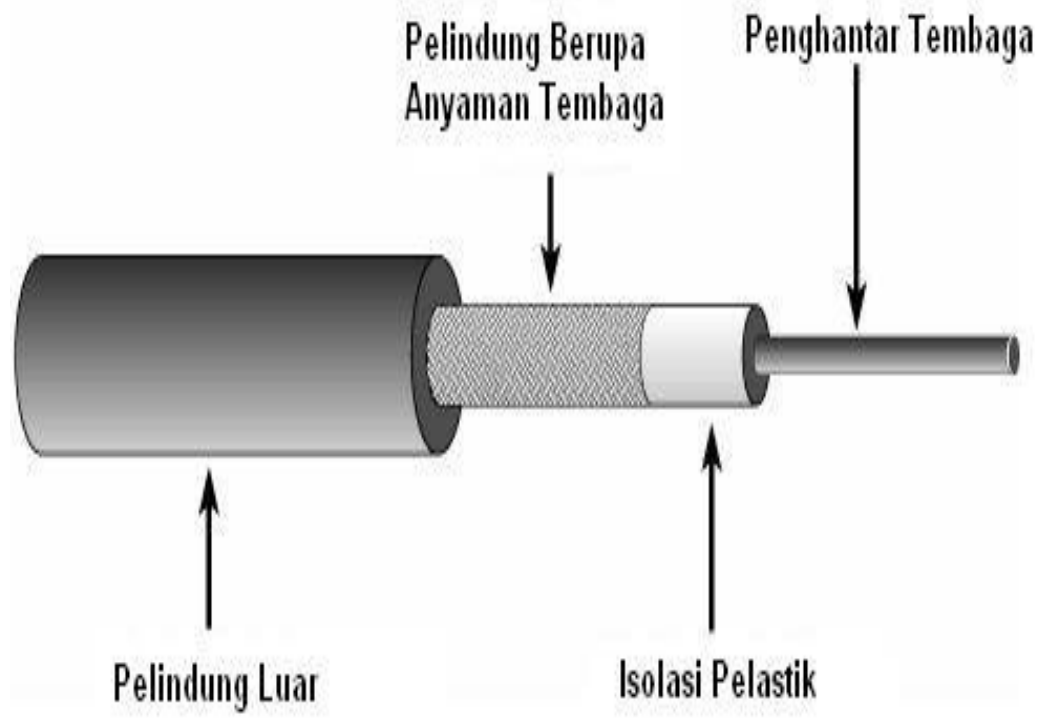

Gambar 2.4 Struktur Material Yang Ada di dalam Konduktor 


\section{COAXIAL CABLE}

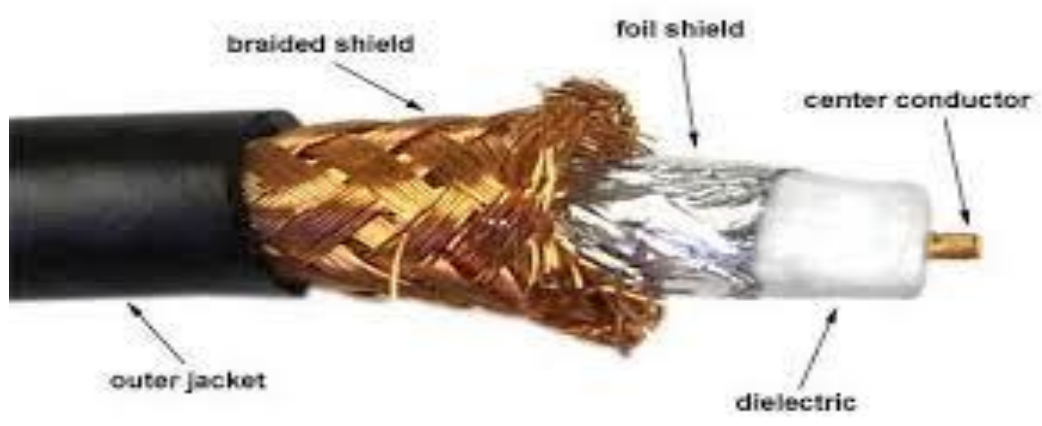

Gambar 2.5 Struktur Penyusun Kabel Coax

Pemakaian bahan isolasi sering dipengaruhi bermacam-macam energi radiasi yang dapat berpengaruh dan mengubah sifat bahan isolasi. Radiasi sinar matahari mempengaruhi umur bahan, khususnya jika bersinggungan dengan oksigen. Sinar ultra violet dapat merusak beberapa bahan organic. T yaitu kekuatan mekanik elastisitas. Sinar $X$ sinar-sinar dari reactor nuklir, partikel-partikel radio isotop juga mempengaruhi kemampuan bahan isolasi. Sifat mekanis bahan yang meliputi kekuatan tarik, modulus elastisitas, dan derajat kekerasan bahan isolasi juga menjadi pertimbangan dalam memilih suatu jenis bahan isolasi.

b. Pembagian Kelas Bahan Penyekat

Bahan penyekat listrik dapat dibagi atas beberapa kelas berdasarkan suhu kerja maksimum, yaitu sebagai berikut[2]:

1. Kelas $Y$, 
suhu kerja maksimum $90^{\circ} \mathrm{C}$, yang termasuk dalam kelas ini adalah bahan berserat organis (seperti Katun, sutera alam, wol sintetis, rayon serat poliamid, kertas, prespan, kayu, poliakrilat, polietilen, polivinil, karet, dan sebagainya) yang tidak dicelup dalam bahan pernis atau bahan pencelup lainnya. Termasuk juga bahan termoplastik yang dapat lunak pada suhu rendah.

2. Kelas A,

suhu kerja maksimum $150^{\circ} \mathrm{C}$, Yaitu bahan berserat dari kelas $\mathrm{Y}$ yang telah dicelup dalam pernis aspal atau kompon, minyak trafo, email yang dicampur dengan vernis dan poliamil atau yang terendam dalam cairan dielektrikum (seperti penyekat fiber pada transformator yang terendam minyak). Bahan -bahan ini adalah katun, sutera, dan kertas yang telah dicelup, termasuk kawat email (enamel) yang terlapis damar-oleo dan damar-polyamide.

3. Kelas $\mathrm{E}$,

suhu kerja maksimum $120^{\circ} \mathrm{C}$, Yaitu bahan penyekat kawat enamel yang memakai bahan pengikat polyvinylformal, polyurethene dan damar epoxy dan bahan pengikat lain sejenis dengan bahan selulosa, pertinaks dan tekstolit, film triacetate, film dan serat polyethylene terephthalate.

4. Kelas B,

suhu kerja maksimum $130^{\circ} \mathrm{C}$, Yaitu Yaitu bahan non-organik (seperti : mika, gelas, fiber, asbes) yang dicelup atau direkat menjadi satu dengan pernis atau kompon, dan biasanya tahan panas (dengan dasar minyak pengering, bitumin sirlak, bakelit, dan sebagainya).

\section{Kelas F,}

suhu kerja maksimum $155^{\circ} \mathrm{C}$, Bahan bukan organik dicelup atau direkat menjadi satu dengan epoksi, poliurethan, atau vernis yang tahan panas tinggi. 


\section{Kelas $\mathrm{H}$,}

suhu kerja maksimum $180^{\circ} \mathrm{C}$, Semua bahan komposisi dengan bahan dasar mika, asbes dan gelas fiber yang dicelup dalam silikon tanpa campuran bahan berserat (kertas, katun, dan sebagainya). Dalam kelas ini termasuk juga karet silikon dan email kawat poliamid murni.

7. Kelas $\mathrm{C}$,

suhu kerja diatas $180^{\circ} \mathrm{C}$, Bahan anorganik yang tidak dicelup dan tidak terikat dengan substansi organic, misalnya mika, mikanit yang tahan panas (menggunakan bahan pengikat anorganik), mikaleks, gelas, dan bahan keramik. Hanya satu bahan organik saja yang termasuk kelas $\mathrm{C}$ yaitu politetra fluoroetilen (Teflon).

\section{Macam-macam bahan penyekat}

1. Bahan penyekat bentuk padat, bahan listrik ini dapat dikelompokkan menjadi beberapa macam, diantaranya yaitu: bahan tambang, bahan berserat, gelas, keramik, plastik, karet, ebonit dan bakelit, dan bahan-bahan lain yang dipadatkan.

2. Bahan penyekat bentuk cair, jenis penyekat ini yang banyak digunakan pada teknik listrik adalah air, minyak transformator, dan minyak kabel.

3. Bahan penyekat bentuk gas, yang sering digunakan untuk keperluan teknik listrik diantaranya : udara, nitrogen, hidrogen, dan karbondioksida.

\subsubsection{Bahan Setengah konduktor (Semi konduktor).}

Semikonduktor merupakan elemen dasar dari komponen elektronika seperti dioda, transistor dan sebuah IC (integrated circuit). Disebut semi atau setengah konduktor, karena bahan ini 
memang bukan konduktor murni. Bahan-bahan logam seperti tembaga, besi, timah disebut sebagai konduktor yang baik sebab logam memiliki susunan atom yang sedemikian rupa, sehingga elektronnya dapat bergerak bebas.Tahun 1906 , pickard merancang suatu diode detector dari Kristal slikon yang disebut dengan nama Cat's wishker, dimana alat yang di buatnya ini terdiri atas suatu kawat yang disambungkan dengan Kristal silikon. Alat inilah yang dikenal sebagai dioada semikonduktor yang pertama.dalam bidang industri penemuan komponen semikonduktor mengakibatkan banyak perubahan dalam kehidupan manusia; terutama dilihat mamfaatnya dalam membantu kelancaran proses industri, diantaranya:

1. Dipergunakannya komponen pasif seperti hambatan,kapasitor,inductor,dan transformator sebagai kelengkapan dalam menyusun suatu rangkaian elektronik.

2. Dibuatnya alat elektronik radio $A M$, radio $F M$, penguat suara hi-fi, TV warna, pemancar FM.

3. Penggunaan alat elektronik untuk mengatur dan menjalankan mesin-mesin industry, dengan ditemukannya; diode tegangan tinggi, diode daya tinggi.

a. Susunan Atom Semikonduktor

Bahan semikonduktor yang banyak dikenal contohnya adalah Silicon (Si), Germanium (Ge) dan Gallium Arsenida (GaAs). Germanium dahulu adalah bahan satu-satunya yang dikenal untuk 
membuat komponen semikonduktor. Namun belakangan, silikon menjadi popular setelah ditemukan cara mengekstrak bahan ini dari alam. Silikon merupakan bahan terbanyak ke dua yang ada di bumi setelah oksigen $\left(\mathrm{O}_{2}\right)$. Pasir, kaca dan batu-batuan lain adalah bahan alam yang banyak mengandung unsur silikon. Dapatkah anda menghitung jumlah pasir di pantai.

Struktur atom kristal silikon, satu inti atom (nucleus) masingmasing memiliki 4 elektron valensi. Ikatan inti atom yang stabil adalah jika dikelilingi oleh 8 elektron, sehingga 4 buah elektron atom kristal tersebut membentuk ikatan kovalen dengan ion-ion atom tetangganya. Pada suhu yang sangat rendah (0oK), struktur atom silikon divisualisasikan seperti pada gambar berikut[8].

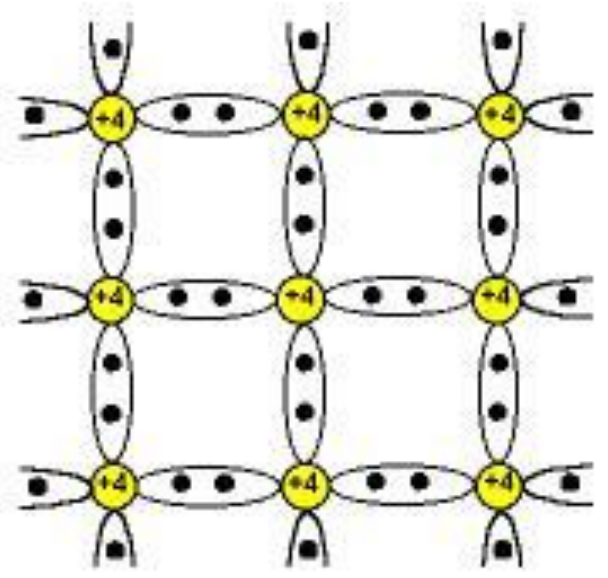

Gambar. 2.6 Struktur Dua Dimensi Kristal Silikon

Ikatan kovalen menyebabkan elektron tidak dapat berpindah dari satu inti atom ke inti atom yang lain. Pada kondisi demikian, bahan semikonduktor bersifat isolator karena tidak ada elektron yang dapat berpindah untuk menghantarkan listrik. Pada suhu 
kamar, ada beberapa ikatan kovalen yang lepas karena energi panas, sehingga memungkinkan elektron terlepas dari ikatannya. Namun hanya beberapa jumlah kecil yang dapat terlepas, sehingga tidak memungkinkan untuk menjadi konduktor yang baik.

Ahli-ahli fisika terutama yang menguasai fisika quantum pada masa itu mencoba memberikan doping pada bahan semikonduktor ini. Pemberian doping dimaksudkan untuk mendapatkan elektron valensi bebas dalam jumlah lebih banyak dan permanen, yang diharapkan akan dapat menghantarkan listrik. Kenyataannya demikian, mereka memang iseng sekali dan jenius. Mengenai sifat dari semikonduktor, berikut table dari sifat bahan semikonduktor :

Tabel 2.1 Mobilitas Semi Konduktor

\begin{tabular}{|c|c|c|}
\hline \multirow{2}{*}{$\begin{array}{c}\text { Jenis kristal } \\
\text { semikonduktor }\end{array}$} & \multicolumn{2}{|c|}{ Mobilitas dalam satuan $\mathrm{cm}^{2} /$ V.s } \\
\cline { 2 - 3 } & Elektron $\left(\mu_{\mathrm{n}}\right)$ & Hole $\left(\mu_{\mathrm{p}}\right)$ \\
\hline $\mathrm{Si}$ & 1.300 & 500 \\
\hline $\mathrm{Ge}$ & 4.500 & 3.500 \\
\hline $\mathrm{InSb}$ & 77.000 & 750 \\
\hline $\mathrm{InPs}$ & 33.000 & 460 \\
\hline $\mathrm{InP}$ & 4.600 & 150 \\
\hline $\mathrm{GaSb}$ & 4.000 & 1.400 \\
\hline
\end{tabular}

b. Jenis-jenis Semikonduktor

Ada dua jenis semikonduktor, yaitu semikonduktor intrinsik dan semikonduktor ekstrinsik.

1. Semikonduktor Intrinsik

Semi konduktor intrinsik adalah semikonduktor yang belum mengalami penyisipan oleh atom akseptor atau atom donor. Pada 
suhu tinggi elektron valensi dapat berpindah menuju pita konduksi, dengan menciptakan hole pada pita valensi. Pengahantar listrik pada semikonduktor adalah elektron dan hole[8].

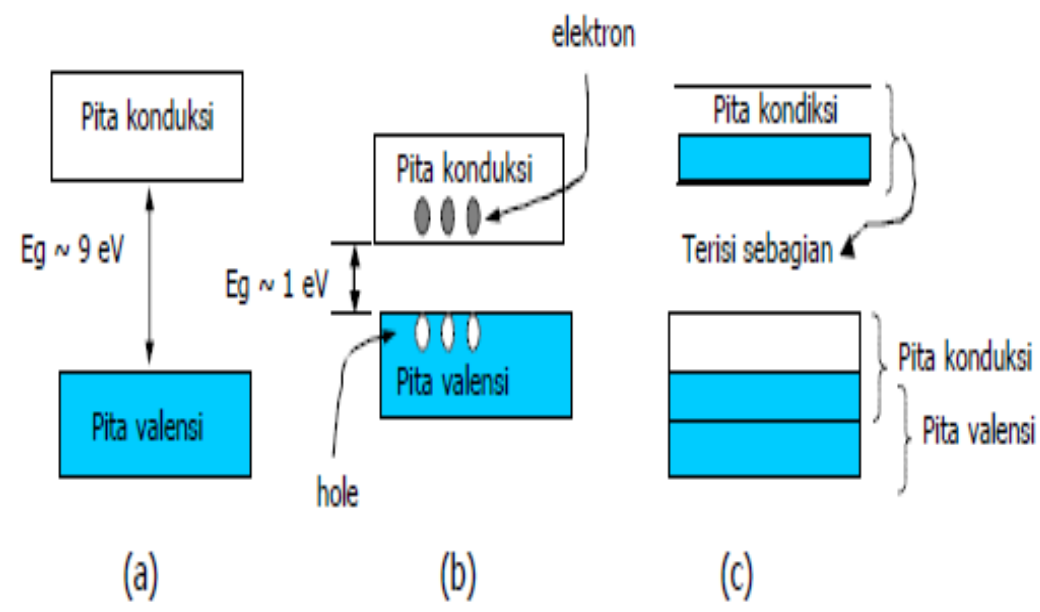

Gambar 2.7 Pita Energi Struktur Pita Untuk (A). Bahan Isolator (B). Bahan Semikonduktor, (C) Bahan Isolator

2. Semikonduktor Ekstrinsik

Semikondutor ekstrinsik merupakan semikonduktor yang memperoleh pengotoran atau penyuntikan (doping) oleh atom asing. 


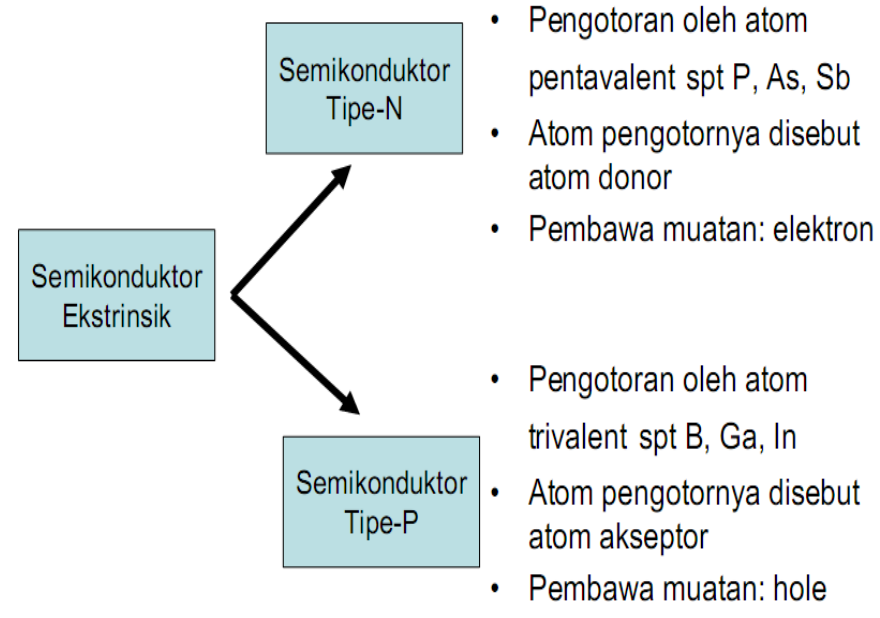

Gambar 2.8. Pengotoran Semi Konduktor

Tujuan doping adalah meningkatkan konduktivitas semikonduktor, dan memperoleh semikonduktor dengan hanya satu pembawa muatan (elektron atau hole) saja. Perbandingan doping :

Atom dopant : Atom murni $=1: 106$ s.d. 108

\subsubsection{Bahan Magnet.}

Benda dapat digolongkan berdasarkan sifatnya. Kemampuan suatu benda menarik benda lain yang berada di dekatnya disebut kemagnetan. Berdasarkan kemampuan benda menarik benda lain dibedakan menjadi dua, yaitu benda magnet dan benda bukan magnet. Namun, tidak semua benda yang berada di dekat magnet dapat ditarik. Oleh karena itu sifat kemagnetan benda dapat digolongkan menjadi:

a. Bahan magnetik (feromagnetik), 
yaitu bahan yang dapat ditarik magnet dengan kuat. Contoh: besi, baja, besi silikon, nikel, kobalt.

b. Bahan non magnetik

1. Paramagnetik, yaitu bahan yang ditarik lemah oleh magnet. Contoh: alumunium, magnesium, wolfram, platina dan kayu.

2. Diamagnetik, yaitu bahan yang ditolak oleh magnet. Contoh: Bismuth, tembaga, emas, perak, seng, garam dapur.

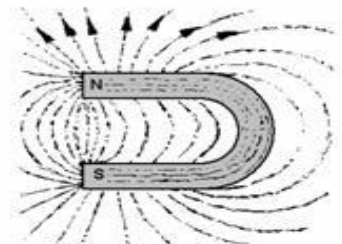

(a)

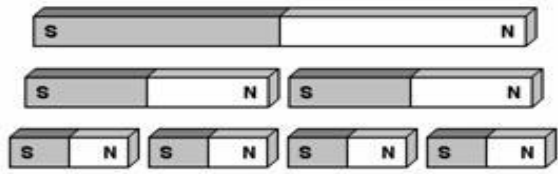

(d)

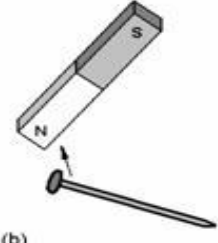

(b)

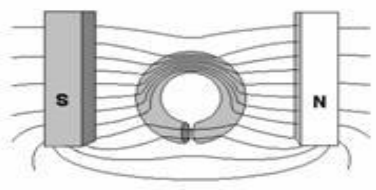

(c)

Gambar 2.9 Jenis - Jenis Magnet

Benda-benda magnetik yang bukan magnet dapat dijadikan magnet. Benda itu ada yang mudah dan ada yang sulit dijadikan magnet. Baja sulit untuk dibuat magnet, tetapi setelah menjadi magnet sifat kemagnetannya tidak mudah hilang. Oleh karena itu, baja digunakan untuk membuat magnet tetap (magnet permanen). 
Besi mudah untuk dibuat magnet, tetapi jika setelah menjadi magnet sifat kemagnetannya mudah hilang. Oleh karena itu, besi digunakan untuk membuat magnet sementara.

Berdasarkan jenis bahan yang digunakan, magnet dapat dibedakan menjadi empat tipe[9]:

1. Magnet Permanen Campuran, Sifat magnet tipe ini adalah keras dan memiliki gaya tarik sangat kuat. Magnet permanen campuran dibagi menjadi:

a. Magnet alcomax, dibuat dari campuran besi dengan almunium.

b. Magnet alnico, dibuat dari campuran besi dengan nikel.

c. Magnet ticonal, dibuat dari campuran besi dengan kobalt.

2. Magnet Permanen Keramik. Tipe magnet ini disebut juga dengan magnadur, terbuat dari serbuk ferit dan bersifat keras serta memiliki gaya tarik kuat.

3. Magnet Besi Lunak. Tipe magnet besi lunak disebut juga stalloy, terbuat dari $96 \%$ besi dan $4 \%$ silicon. Sifat kemagnetannya tidak keras dan sementara.

4. Magnet Pelindung

Tipe magnet ini disebut juga mumetal, terbuat dari $74 \%$ nikel, $20 \%$ besi, $5 \%$ tembaga, dan $1 \%$ mangan. Magnet ini tidak keras dan bersifat sementara.

Berdasarkan penggolongan magnet buatan diatas serta kemampuan bahan menyimpan sifat magnetnya, kita dapat menggolongkan bahan-bahan magnetic ke dalam magnet keras dan magnet lunak. Sebagai contoh bahan-bahan magnet keras ialah baja dan alcomax. Bahan ini sangat sulit untuk dijadikan magnet. Namun demikian, setelah bahan tersebut menjadi magnet, bahanbahan magnet keras ini akan dapat menyimpan sifat magnetiknya 
relative sangat lama. Karena pertimbangan atau alas an itulah bahan-bahan magnet keras ini lebih banyak dipakai untuk membuat magnet tetap (permanen). Contoh pemakaiannya adalah pita kaset dan kompas. Bahan-bahan magnet lunak, misalnya besi dan mumetal, jauh lebih mudah untuk dijadikan magnet. Namun demikian, sifat kemagnetannya bersifat sementara atau mudah hilang. Itulah sebabnya, bahan-bahan magnet lunak ini banyak dipakai untuk membuat electromagnet (magnet listrik) [10].

\subsubsection{Bahan Super Konduktor.}

Bahan superkonduktor adalah suatu bahan yang dapat mengalirkan arus listrik tanpa tahanan listrik sedikitpun bahan ini terdiri dari campuran unsur-unsur tertentu yang dapat mengalirkan arus listrik tanpa tahanan pada suhu yang sangat rendah[7]. Arus yang mengalir pada rangkaian tertutup dari bahan superkonduktor akan terus mengalir selamanya. Superkonduktivitas ini disebut juga sebagai "fenomena quantum makroskopis". Suatu fenomena yang terjadi pada suatu bahan jika berada pada suhu yang sangat rendah akan menunjukkan ciri-ciri:

1. Resistansi menjadi nol.

2. Bersifat menolak medan magnet (Efek Meissner) 


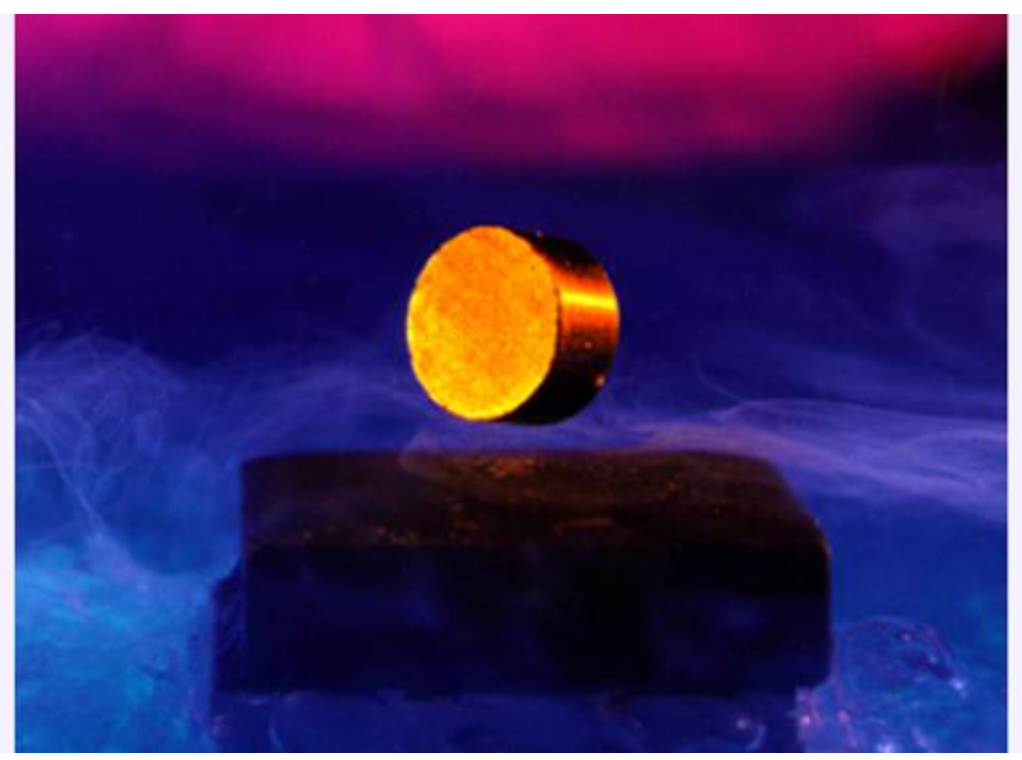

Gambar 2.10 Super Konduktor

Pada gambar 2.5 nampak jika super konduktor diletakkan di atas magnet, maka super konduktor tersebut akan dapat melayang.

a. Sejarah singkat bahan Superkonduktor

1. Pada tahun 1911. Heike Kamerlingh mendinginkan air raksa (mercury) dalam helium cair pada suhu 4oK (269oC) dan mendapati resistansinya nol.

2. Sedangkan pada tahun 1933. Walter Meissner menemukan jika benda didinginkan pada suhu yang sangat rendah maka benda tersebut akan memiliki medan magnet sendiri yang menolak magnet lain bila didekatkan. Hal ini disebut juga sebagai efek meissner. 
3. Pada tahun 1941. Ditemukan niobium-nitride yang menjadi superkonduktor pada suhu $16^{\circ} \mathrm{K}$.

4. Pada tahun 1980. Ditemukan bahan superkonduktor dengan bahan dasar karbon (bahan organik).

5. Sedangkan pada tahun 1986. Ditemukan bahan superkonduktor dengan bahan dasar keramik (bahan isolator).

6. Pada tahun 1993. Ditemukan paduan raksa, thalium, barium, kalsium, tembaga dan oksigen yang menjadi superkonduktor pada suhu $138^{\circ} \mathrm{K} 138^{\circ} \mathrm{K}$ (suhu tertinggi) [11].

b. Temperatur Kritis (Tc)

Ketika temperature bahan diturunkan dari temperature ruang normal sampai pada batas temperature tertentu bahan ini akan memiliki sifat superkonduktor Temperatur bahan pada saat terjadinya perubahan sifat bahan ini dinamakan sebagai temperature kritis (Tc)[9].

c. Suhu Pemadaman Superkonduktor

Suhu pemadaman merupakan batas suhu untuk merusak sifat superkonduktor. Artinya pada suhu ini superkonduktor akan rusak. 


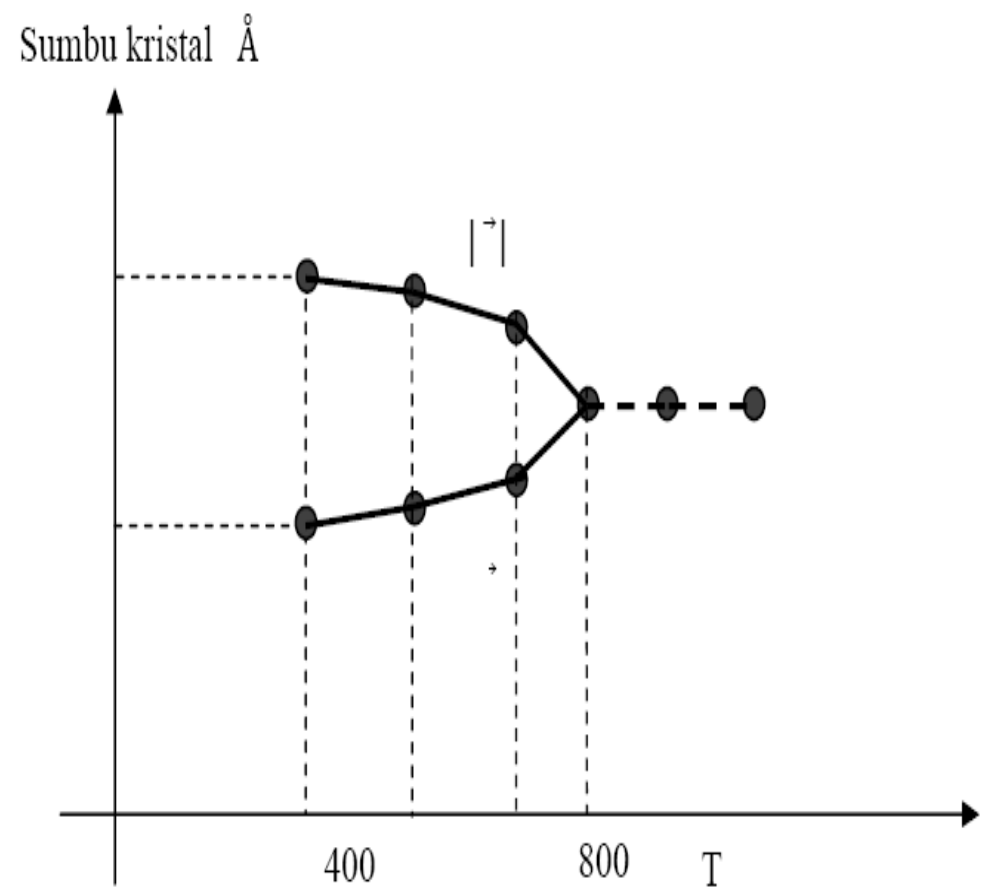

Gambar 2.11 Vektor suhu Bahan Superkonduktor

Pada grafik diatas dapat kita lihat bahwasanya makin tinggi suhu yang diberikan pada bahan superkonduktor, maka struktur Kristal superkonduktor tidak lagi berbentuk ortorombik. Maka dengan adanya perubahan struktur kristal superkonduktor, suatu bahan akan kehilangan sifat superkonduktornya. 


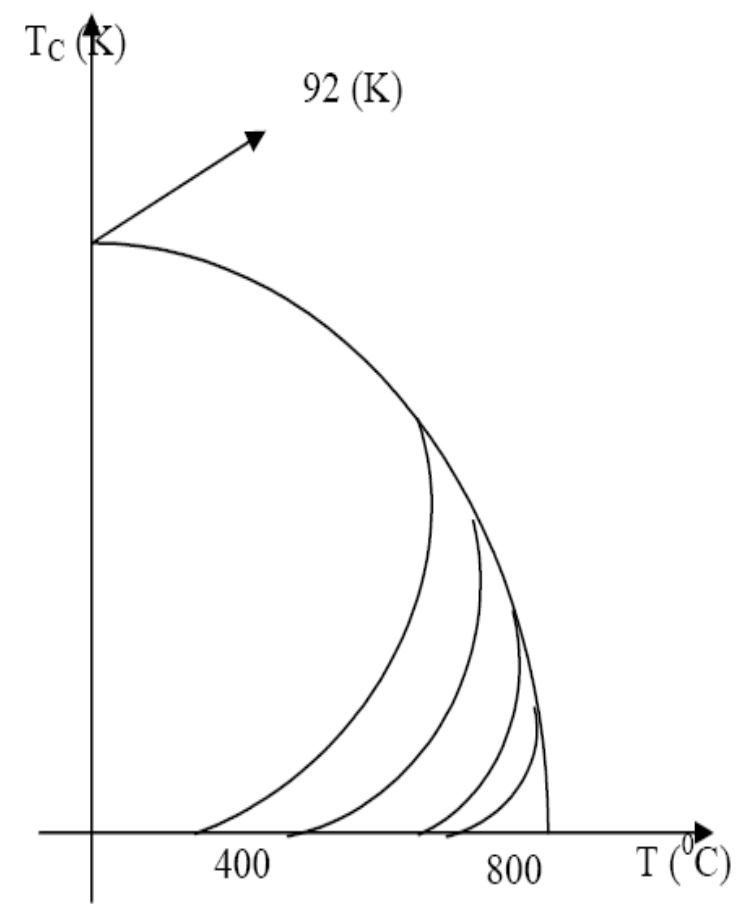

Gambar 2.12 Grafik Hubungan Antara Suhu Kritis Dan Suhu Bahan Superkonduktor

Grafik diatas menunjukan hubungan antara suhu kritis dengan suhu bahan superkonduktor. Jika suhu yang diberikan pada bahan superkonduktor makin besar, maka suhu kritis bahan akan mendekati nilai nol kelvin[12].

d. Bahan Superkonduktor terjadi pada Bahan sebagai berikut :

1. Bahan konduktor murni (Aluminium).

2. Berbagai campuran logam(alloy).

3. Bahan semikonduktor. 


\section{Bahan isolator (keramik)}

e. Bahan Superkonduktor tidak terjadi pada :

1. Emas.

2. Perak.

3. Bahanferromagnetik

f. Kelas Superkonduktor

1. Kelas I, (Low Temperature Superconductor) adalah bahan yang harus berada pada suhu yang sangat rendah untuk memiliki sifat superkonduktor.

2. Kelas II (High Temperature Superconductor) adalah bahan yang dapat berada pada suhu diatas bahan kelas I untuk menjadi superkonduktor.

\subsubsection{Bahan Serat optik.}

Pada dasarnya kata komunikasi merupakan suatu kata yang dapat diartikan sebagai cara untuk menyampaikan data atau informasi. Komunikasi data merupakan cara mengirimkan data menggunakan system transmisi elektronik dari satu komputer ke komputer lain. Sedangkan data itu sendiri merupakan sinyal elektromagnetik yang dibangkitkan oleh sumber data yang dapat ditangkap dan dikirimkan ke komputer penerima[13].

\section{a. Pengertian Serat Optik}

Serat Optik adalah saluran transmisi yang terbuat dari kaca atau plastik yang digunakan untuk mentransmisikan sinyal cahaya dari suatu tempat ke tempat lain. Cahaya yang ada di dalam Serat Optik sulit keluar karena indeks bias dari kaca lebih besar daripada indeks bias dari udara. Sumber cahaya yang digunakan adalah laser karena 
laser mempunyai spektrum yang sangat sempit. Kecepatan transmisi Serat Optik sangat tinggi sehingga sangat bagus digunakan sebagai saluran komunikasi.

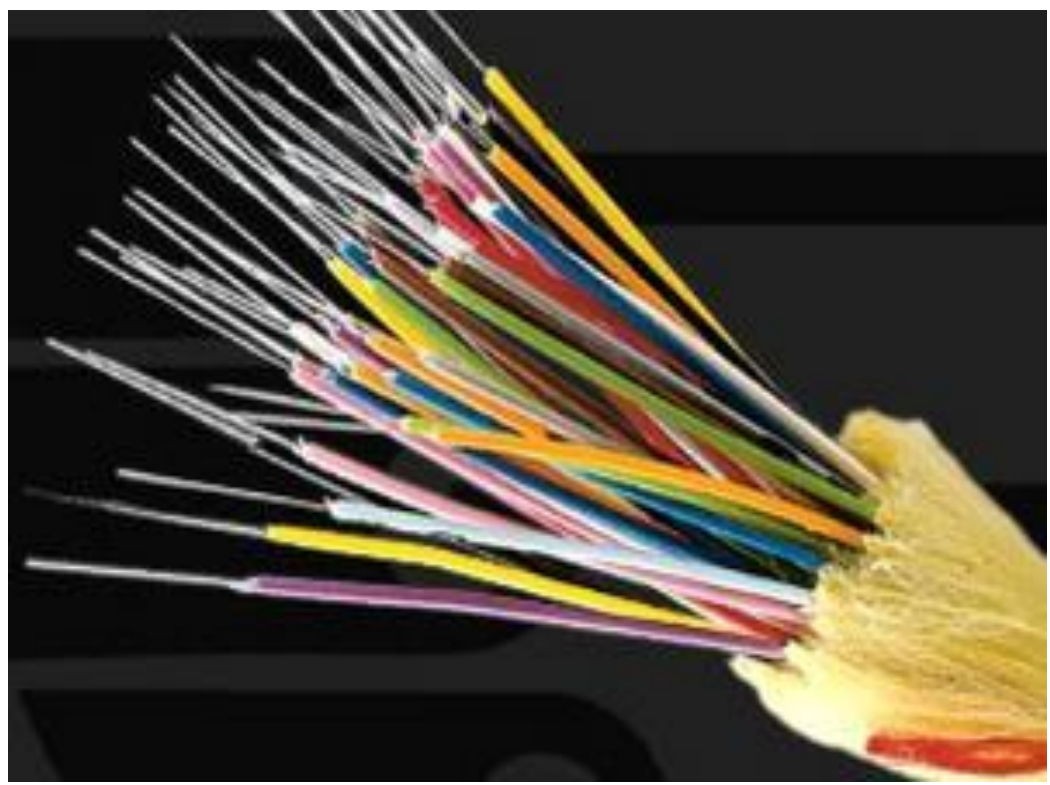

Gambar 2.13 Serat optik

Serat Optik umumnya digunakan dalam sistem telekomunikasi serta dalam pencahayaan, sensor, dan Optik pencitraan. Serat Optik terdiri dari 2 bagian, yaitu cladding dan core. Cladding adalah selubung dari core. Cladding mempunyai indek bias lebih rendah dari pada core akan memantulkan kembali cahaya yang mengarah keluar dari core kembali kedalam core lagi[6].

Efisiensi dari Serat Optik ditentukan oleh kemurnian dari bahan penyusun gelas. Semakin murni bahan gelas, semakin sedikit 
cahaya yang diserap oleh Serat Optik. Karakteristik yang membedakan Serat optik dari twisted pair/coaxibel cable :

1. Kapasitas yang lebih besar.

2. Ukuran yang lebih kecil \& bobot yang lebih ringan.

3. Atenuasi yang lebih rendah.

4. Isolasi elektromagnetik.

5. Jarak repeater yang lebih besar

b. Struktur Serat Optik

Struktur Serat Optik pada umumnya terdiri dari 3 bagian yaitu:

1. Bagian yang paling utama dinamakan bagian inti (core), dimana gelombang cahaya yang dikirimkan akan merambat dan mempunyai indeks bias lebih besar dari lapisan kedua. Terbuat dari kaca (glass) yang berdiameter antara 2 ? 125 ?m, dalam hal ini tergantung dari jenis Serat optiknya.

2. Bagian yang kedua dinamakan lapisan selimut (Cladding), dimana bagian ini mengelilingi bagian inti dan mempunyai indeks bias lebih kecil dibandingkan dengan bagian inti. Terbuat dari kaca yang berdiameter antara 0,5 mm - 0,25 $\mathrm{mm}$, juga tergantung dari jenis Serat optiknya.

3. Bagian yang ketiga dinamakan lapisan jaket (Coating), dimana bagian ini merupakan pelindung lapisan inti dan selimut yang terbuat dari bahan plastik yang elastic.

Pada serat optik harus ada beberapa hal yang harus diperhatikan, antara lain [14]:

a. Numerical Aperture (NA), Karakteristik Serat Optik Numerical Aperture merupakan parameter yang 
merepresentasikan sudut penerimaan maksimum dimana berkas cahaya masih bisa diterima dan merambat didalam inti Serat. Sudut penerimaan ini dapat beraneka macam tergantung kepada karakteristik indeks bias inti dan selubung Serat Optik. Jika sudut datang berkas cahaya lebih besar dari NA atau sudut kritis maka berkas tidak akan dipantulkan kembali ke dalam Serat melainkan akan menembus cladding dan akan keluar dari Serat. Semakin besar NA maka semakin banyak jumlah cahaya yang diterima oleh Serat. Akan tetapi sebanding dengan kenaikan NA menyebabkan lebar pita berkurang, dan rugi penyebaran serta penyerapan akan bertambah. Oleh karena itu, nilai NA besar hanya baik untuk aplikasi jarakpendek dengan kecepatan rendah.

b. Redaman, Redaman/atenuasi Serat Optik merupakan karakteristik penting yang harus diperhatikan mengingat kaitannya dalam menentukan jarak pengulang (repeater), jenis pemancar dan penerima optik yang harus digunakan. Redaman serat biasanya disebabkan oleh karena penyerapan/absorpsi energi sinyal oleh bahan, efek scattering/penghamburan dan pengaruh radiasi/pembengkokan. Semakin besar atenuasi berarti semakin sedikit cahaya yang dapat mencapai detektor dan dengan demikian semakin pendek kemungkinan jarak span antar pengulang.

c. Dispersi, Dispersi adalah pelebaran pulsa yang terjadi ketika sinyal merambat melalui sepanjang serat optik. Dispersi akan membatasi lebar pita (bandwidth) dari Serat. Dispersi yang terjadi pada Serat secara garis besar ada dua yaitu dispersi intermodal dan dispersi intramodal dikenal dengan 
nama lain dispersi kromatik disebabkan oleh dispersi material dan dispersi wavegiude.

Serat optic terbuat dari bahan dielektrik berbentuk seperti kaca (glass). Di dalam Serat inilah energi cahaya yang dibangkitkan oleh sumber cahaya disalurkan (ditransmisikan) sehingga dapat diterima di ujung unit penerima (receiver).

c. Kategori Dasar Aplikasi Serat Optik

Ada 4 kategori dasar aplikasi yang sangat pnting untuk serat optik:

a. Long Haul trunk biasa digunakan untuk jaringan telepon panjangnya kira - kira 1500 km, kapasitasnya tinggi.

b. Metropolitan trunk : memiliki panjang kira - kira $12 \mathrm{~km}$ dan memiliki dan memiliki kurang lebih 100.000 saluran.

c. Rural exchange trunk : memiliki panjang sirkuit berkisar antara 40 sampai $160 \mathrm{~km}$, menghubungkan daerah perkotaan dan pedesaan, dan memiliki saluran suarakurang dari 5000.

d. Subcriber loop local area network : adalah serat yang langsung menghubungkan stasiun sentral secara langsung ke pelanggan.

\section{Jenis Kabel Serat Optik}

Menurut jenisnya, kabel serat optik dibedakan menjadi 3 macam :

a. Single Mode Fiber, Pada single mode fiber, terlihat pada gambar bahwa index bias akan berubah dengan segera pada batas antara core dan cladding (step index). Bahannya terbuat dari silica glass baik untuk cladding maupun corenya. Diameter core jauh lebih kecil 10 ?m) dibandingkan dengan diameter cladding, konstruksi 
demikian dibuat untuk mengurangi rugi-rugi transmisi akibat adanya fading. Single mode fiber sangat baik digunakan untuk menyalurkan informasi jarak jauh karena di samping rugi-rugi transmisi yang kecil juga mempunyai band frkuensi yang lebar. Misalnya untuk ukuran 10/125 ?]m, pada panjang gelombang cahaya $1300 \mathrm{~nm}$, redaman maksimumnya 0,4-0,5 dB/km dan lebar band frekwensi minimum untuk $1 \mathrm{~km}$ sebesar $10 \mathrm{GHz}$.. Perambatan cahaya dalam single mode fiber adalah sebagai berikut. Single mode fiber dapat juga dibuat dengan index bias yang berubah secara perlahanlahan (graded index).

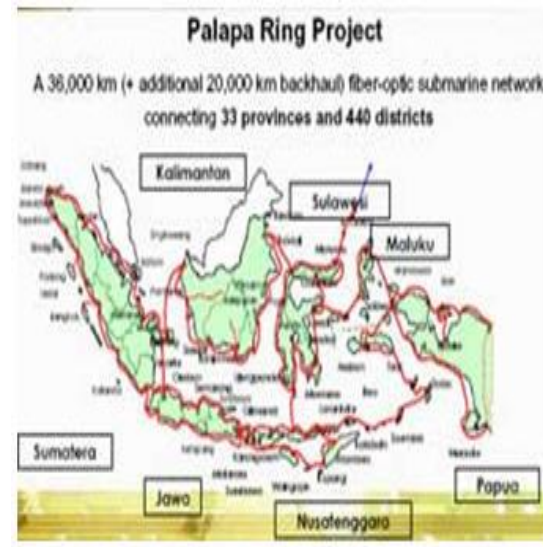

Provek Palapa Ring

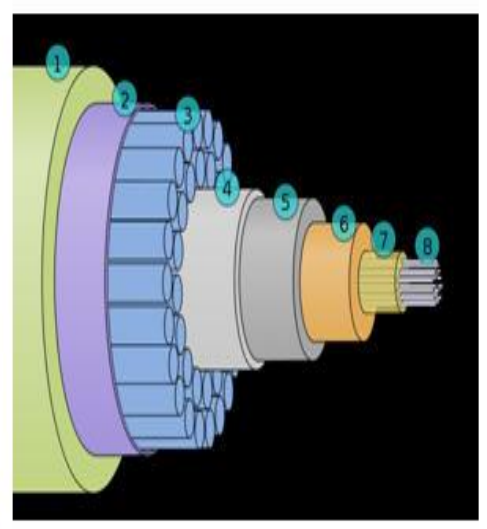

Penampang kabel fiber optic bawah /aut:

1-Polyethylene, 2-Mylar tape, 3-Stranded steelwires,

4-Aluminium water barrier, 5 - Polycarbonate

6-Copper or aluminiumtube, 7-Petroleum jelly,

8-0ptical fibers

Gambar 2.14 Kabel laut yang Mempergunakan Serat Optik 


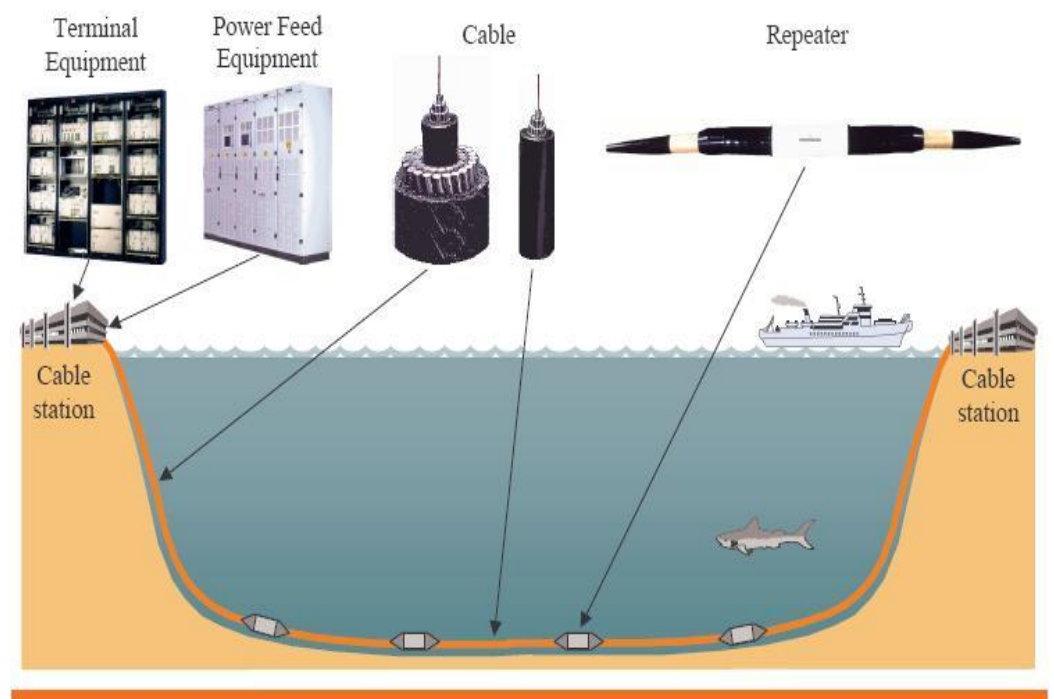

Gambar 2.15 Proses Pemasangan Kabel Laut

b. Multimode Step Index Fiber, Serat optik ni pada dasarnya mempunyai diameter core yang besar (50 - 400 um) dibandingkan dengan diameter cladding (125 - 500 um). Sama halnya dengan single mode fiber, pada serat optik ini terjadi perubahan index bias dengan segera (step index) pada batas antara core dan cladding. Diameter core yang besar (50 - 400 um) digunakan untuk menaikkan effisiensi coupling pada sumber cahaya yang tidak koheren seperti LED. Karakteristik penampilan serat optik ini sangat bergantung pada macam material/bahan yang digunakan. Berdasarkan hasil penelitian, penambahan prosentase bahan silica pada serat optik ini akan meningkatkan penampilan (performance). Tetapi jenis serat optik ini tidak 
populer karena meskipun kadar silicanya ditingkatkan, rugirugi dispersi sewaktu transmit tetap besar, sehingga hanya baik digunakan untuk menyalurkan data/informasi dengan kecepatan rendah dan jarak relatif dekat. Perambatan gelombang pada multimode step index fiber sebagai berikut :

c. Multimode Graded index, Multimode graded index dibuat dengan menggunakan bahan multi component glass atau dapat juga dengan silica glass baik untuk core maupun claddingnya. Pada serat optik tipe ini, indeks bias berubah secara perlahan-lahan (graded index multimode). Indeks bias inti berubah mengecil perlahan mulai dari pusat core sampai batas antara core dengan cladding. Makin mengecilnya indeks bias ini menyebabkan kecepatan rambat cahaya akan semakin tinggi dan akan berakibat dispersi waktu antara berbagai mode cahaya yang merambat akan berkurang dan pada akhirnya semua mode cahaya akan tiba pada waktu yang bersamaan dipenerima (ujung serat optik). Diameter core jenis serat optik ini lebih kecil dibandingkan dengan diameter core jenis serat optic Multimode Step Index, yaitu 30 - 60 um untuk core dan 100 - 150 um untuk claddingnya.

Biaya pembuatan jenis serat optik ini sangat tinggi bila dibandingkan dengan jenis Single mode. Rugi-rugi transmisi minimum adalah sebesar $0,70 \mathrm{~dB} / \mathrm{km}$ pada panjang gelombang 1,18 um dan lebar band frekwensi $150 \mathrm{MHz}$ sampai dengan $2 \mathrm{GHz}$. Oleh karenanya jenis serat optik ini sangat ideal untuk menyalurkan informasi pada jarak menengah dengan menggunakan sumber cahaya LED maupun LASER, di samping juga penyambungannya 
yang relatif mudah. Perambatan gelombang cahaya pada jenis serat optik ini sebagai berikut :

D. Pembagian Jenis Kabel Serat Optik

Pembagian serat optik dapat dilihat dari 2 macam perbedaan [14]:

1. Berdasarkan Mode yang dirambatkan :

Single mode : serat optik dengan core yang sangat kecil, diameter mendekati panjang gelombang sehingga cahaya yang masuk ke dalamnya tidak terpantul-pantul ke dinding cladding.

Reliabilitas dari serat optik dapat ditentukan dengan satuan BER (Bit Error Rate). Salah satu ujung serat optik diberi masukan data tertentu dan ujung yang lain mengolah data itu. Dengan intensitas laser yang rendah dan dengan panjang serat mencapai beberapa km, maka akan menghasilkan kesalahan. Jumlah kesalahan persatuan waktu tersebut dinamakan BER. Dengan diketahuinya BER maka, Jumlah kesalahan pada serat optik yang sama dengan panjang yang berbeda dapat diperkirakan besarnya.

Multi mode : serat optik dengan diameter core yang agak besar yang membuat laser di dalamnya akan terpantul-pantul di dinding cladding yang dapat menyebabkan berkurangnya bandwidth dari serat optik jenis ini.

b. Berdasarkan indeks bias core :

Step indeks : pada serat optik step indeks, core memiliki indeks bias yang homogen.

Graded indeks : indeks bias core semakin mendekat ke arah cladding semakin kecil. Jadi pada graded indeks, pusat core memiliki nilai indeks bias yang paling besar. serat graded indeks 
memungkinkan untuk membawa bandwidth yang lebih besar, karena pelebaran pulsa yang terjadi dapat diminimalkan.

\section{E. Karakter Transmisi pada Serat Optik}

Sistem serat optic beroperasi pada daerah 100.000 sampai dengan $1000.000 \mathrm{GHz}$. Prinsip kerja transmisi serat optic adalah sebagai berikut :

Cahaya dari suatu sumber masuk kesilinder kaca atau pelastik core. Berkas cahaya dipantulkan dan dipropagasikan sepanjang serat, sedangkan sebagian lagi diserap oleh material sekitarnya.

Serat optic mentransmisikan berkas cahaya yang ditandai dengan sebuah sinyal dengan memakai total internal reflection. Refleksi jenis ini terjadi pada berbagai media transparan yang memiliki indeks refraksilebih tinggi dibandingkan media disekelilingnya.

Dampak, serat optic bertindak sebagai pengarah gelombang (waveguide) untuk frekuensi dalam rentang sekitar 100 terra hingga 1000 terra hertz. Hal ini menutupi bagian inframerah dan cahaya tampak.

\subsection{Tugas}

1. Untuk apakah diketahui jenis bahan atau material?

2. Bagaimana pengelompokan bahan menurut jenis dan sifatnya?

3. Apakah aplikasi penggunaan super konduktor untuk saat ini ?

4. Apakah Magnet di musnahkan? 


\section{Bab III}

\section{Sifat Bahan Listrik}

Tujuan Instruksional :

Setelah mempelajari Bab ini, di harapkan pembaca dapat memahami :

1. Jenis Bahan atau Material yang menyusun materi listrik.

2. Mengetahui ikatan atom yang menyusun bahan listrik.

3. Mengetahui sifat Bahan Listrik

\subsection{Jenis Bahan atau Material}

Jenis bahan atau material ini merupakan suatu hal yang harus di dalami sebelum malat yang disusun oleh material - material itu dipergunakan dalam kehidupan sehari - hari. Jenis bahan atau material itu tersusun dari bentuk atom dengan berbagai ikatan ikatan yang ada. Ikatan antar atom, yaitu, ikatan ion atau ikatan kovalen[4].

Secara global, bahwa Jenis Bahan / Material dapat dibagi menjadi 2, yaitu :

1. Murni unsur

- logam (Fe, Hg)

- nonlogam [C (grafit, intan), Si, S]

2. Senyawa

- oksida / keramik (tanah liat, SiO2)

- polimer (kayu, karet, plastik) 


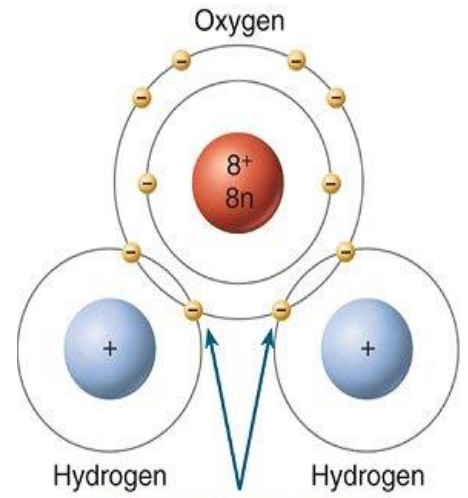

Electrons from hydrogen

(a) Electron shells in a water molecule

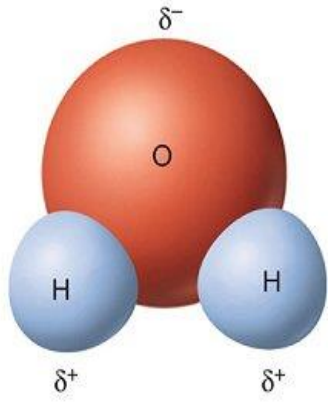

(b) Distribution of partial charges in a water molecule

Gambar 3.1. (a) Molekul Air. (b) Distribusi Ion Pada Molekul Air

\subsection{Jenis Ikatan Antar Atom}

Semua atom memiliki kecenderungan untuk stabil seperti konfigurasi gas mulia. Salah satu cara untuk menuju kestabilan adalah berikatan dengan atom lain dengan cara serah terima (transfer) electron ataupun dengan jalan berbagi electron untuk dipakai bersama-sama (sharing).
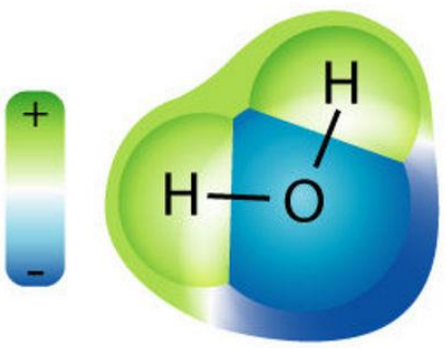

Gambar 3.2 Ikatan Kimia Dalam Molekul 
Kimiawan Jerman Albrecht Kossel (1853-1927) menganggap kestabilan gas mulia disebabkan konfigurasi elektronnya yang penuh (yakni, konfigurasi elektron di kulit terluarnya, kulit valensi, terisi penuh). la berusaha memperluas interpretasinya ke atom lain. Atom selain gas mulia cenderung mendapatkan muatan listrik (elektron) dari luar atau memberikan muatan listrik ke luar, bergantung apakah jumlah elektron di kulit terluarnya lebih sedikit atau lebihbanyak dari atom gas mulia yang terdekat dengannya.

Ikatan kimia secara garis besar dapat dibagi menjadi dua jenis, yaitu ikatan antar atom dan ikatan antar molekul. ikatan antar molekul akan dibahas pada kelas XI setelah teori atom kuantum (modern) diterima oleh siswa, sedangkan pada kesempatan kali ini kita akan membahas ikatan antar atom.

Ikatan antar atom dibagi menjadi 3 kelas yaitu ikatan ionic, ikatan kovalen dan ikatan logam.

1. Ikatan Ionic (elektrovalen),

Bila suatu atom kehilangan elektron, atom tersebut akan menjadi kation yang memiliki jumlah elektron yang sama dengan gas mulia terdekat, sementara bila atom mendapatkan elektron, atom tersebut akan menjadi anion yang memiliki jumlah elektron yang sama dengan atom gas mulia terdekatnya. la menyimpulkan bahwa gaya dorong pembentukan ikatan kimia adalah gaya elektrostatik antara kation dan anion.

Ikatan kimia yang dibentuk disebut dengan ikatan ionik. Ikatan ionic ini secara umum terjadi antara logam dengan non logam dengan serah terima electron dari logam (secara umum) kepada non logam. Misalkan dalam seuatu kasus, kulit $\mathrm{K}$ dan $\mathrm{L}$ atom natrium $(11 \mathrm{Na})$ terisi penuh elektron, tetapi hanya ada satu elektron 
di kulit terluar (M). Jadi natrium dengan mudah kehilangan satu elektron terluar ini menjadi ion natrium $\mathrm{Na}+$ yang memiliki konfigurasi elektron yang sama dengan atom neon $10 \mathrm{Ne}$ (1s22s22p6).

Konfigurasi elektron atom khlor (17Cl) adalah 1s22s22p63s23p5. Bila satu atom khlorin menangkap satu elektron untuk melengkapi kulit M-nya agar menjadi terisi penuh, konfigurasi elektronnya menjadi (1s22s22p63s23p6) yang identik dengan konfigurasi elektron argon Ar. Demikianlah kiranya senyawa $\mathrm{NaCl}$ terbentuk karena atom $\mathrm{Na}$ melepas 1 elektron untuk diterima oleh $\mathrm{Cl}$.

$$
\begin{aligned}
& \mathrm{Na} \rightarrow \mathrm{Na}^{+}+\mathrm{e}^{-} \\
& \mathrm{Cl}+\mathrm{e}^{-} \rightarrow \mathrm{Cl}^{-} \\
& \hline \mathrm{Na}+\mathrm{Cl} \rightarrow \mathrm{Na}^{+}+\mathrm{Cl}^{-} \\
& \mathrm{Na}^{+}+\mathrm{Cl}^{-} \text {membentuk ikatan ion } \mathrm{NaCl} \text { (natrium klorida) }
\end{aligned}
$$

Gambar 3.3 Ikatan Ion NaCl (Natrium Chlorida)

Tabel 3.1 Golongan Kation dan Anion

\begin{tabular}{|l|l|}
\hline \multicolumn{1}{|c|}{ Golongan Kation } & \multicolumn{1}{|c|}{ Golongan Anion } \\
\hline $\begin{array}{l}\text { Logam Alkali (IA), Logam Alkali Tanah } \\
\text { (IIA), Logam III A dan logam IV A dan } \\
\text { Logam Transisi (gol. B) }\end{array}$ & $\begin{array}{l}\text { Halogen (VIIA), Kalkogen (VI A) dan } \\
\text { golongan nitrogen (VA) }\end{array}$ \\
\hline
\end{tabular}

Secara umum ikatan ionic terjadi antara kation dan anion dari golongan-golongan berikut:

i. Golongan Kation.

ii. Golongan Anion 
Logam Alkali (IA), Logam Alkali Tanah (IIA), Logam III A dan logam IV A dan Logam Transisi (gol. B)

Halogen (VIIA), Kalkogen (VI A) dan golongan nitrogen (VA)

Sedangkan untuk sifat-sifat senyawa ion adalah sebagai berikut :

1. Dalam bentuk padatan tidak menghantar listrik karena partikel-partikel.

2. Ionnya terikat kuat pada kisi, sehingga tidak ada elektron yang bebas bergerak.

3. Leburan dan larutannya menghantarkan listrik.

4. Umumnya berupa zat padat kristal yang permukaannya keras dan sukar digores.

5. Titik leleh dan titik didihnya tinggi.

6. Larut dalam pelarut polar dan tidak larut dalam pelarut nonpolar.

\section{Ikatan Kovalen}

Sekitar tahun 1916, dua kimiawan Amerika, Gilbert Newton Lewis (1875-1946) dan Irving Langmuir (1881-1957), secara independen menjelaskan apa molekul non polar. Titik krusial teori mereka adalah penggunaan bersama elektron oleh dua atom sebagai cara untuk mendapatkan kulit terluar yang diisi penuh elektron.

Penggunaan bersama pasangan elektron oleh dua atom atau ikatan kovalen adalah konsep baru waktu itu. Ikatan kovalen adalah ikatan yang terjadi antara unsur nonlogam dengan unsur nonlogam yang lain dengan cara pemakaian bersama pasangan elektron. Adakalanya dua atom dapat menggunakan lebih dari satu pasang elektron. 
Apabila yang digunakan bersama dua pasang atau tiga pasang maka akan terbentuk ikatan kovalen rangkap dua atau rangkap tiga. Sifat-sifat senyawa kovalen secara umum adalah sebagai berikut.

1. Pada suhu kamar umumnya berupa gas (misal H2, O2, N2, $\mathrm{Cl}$, CO2), cair (misalnya: $\mathrm{H} 2 \mathrm{O}$ dan $\mathrm{HCl}$ ), ataupun berupa padatan.

2. Titik didih dan titik lelehnya rendah, karena gaya tarikmenarik antarmolekulnya lemah meskipun ikatan antaratomnya kuat.

3. Larut dalam pelarut nonpolar dan beberapa di antaranya dapat berinteraksi dengan pelarut polar.

4. Larutannya dalam air ada yang menghantar arus listrik (misal $\mathrm{HCl}$ ) tetapi sebagian besar tidak dapat menghantarkan arus listrik, baik padatan, leburan, atau larutannya.



Gambar 3.4 Jenis Ikatan Kovalen 


\section{๘ elektron bebas \\ elektron ikatan \\ $\mathrm{H}: \mathrm{O}: \mathrm{H}$}

Gambar 3.5 Ikatan Ion

Jumlah elektron valensi yang digunakan untuk berikatan tergantung pada kebutuhan tiap atom untuk mencapai konfigurasi elektron seperti gas mulia (kaidah duplet atau oktet). Penggunaan bersama pasangan elektron digambarkan oleh Lewis menggunakan titik elektron.

Lewis mengembangkan simbol untuk ikatan elektronik untuk membentuk molekul (struktur Lewis atau rumus Lewis) yang akan di bahas dalam bab Struktur Molekul Sesuai Aturan Lewis. Selain ikatan kovalen tunggal dan rangkap, juga ditemukan ikatan kovalen koordinasi karena atom pusat memberikan electron kepada atom pasangan dan atom pasangan tidak memberikan electron untuk berpasangan namun atom pusat tetap menganggap electron yang diberikan tetap menjadi miliknya, lebih mirip menyewakan electron untuk berpasangan.

1. Ikatan Kovalen Tunggal, Ikatan kovalen tunggal terjadi apabila dua atom yang berpasangan masing-masing menyerahkan sebuah elektron yang kemudian dipakai bersama. Hal ini terjadi pada $\mathrm{HCl}$, dimana $\mathrm{H}$ menyerahkan 1 
elektron, dan $\mathrm{Cl}$ juga menyerahkan 1 elektron, kemudian dipakai bersama-sama untuk berpasangan. Contoh lain dari ikatan kovalen tunggal adalah : $\mathrm{HI}, \mathrm{HF}, \mathrm{H} 2 \mathrm{O}, \mathrm{CH} 4, \mathrm{NH} 3$ dan $\mathrm{H} 2$.

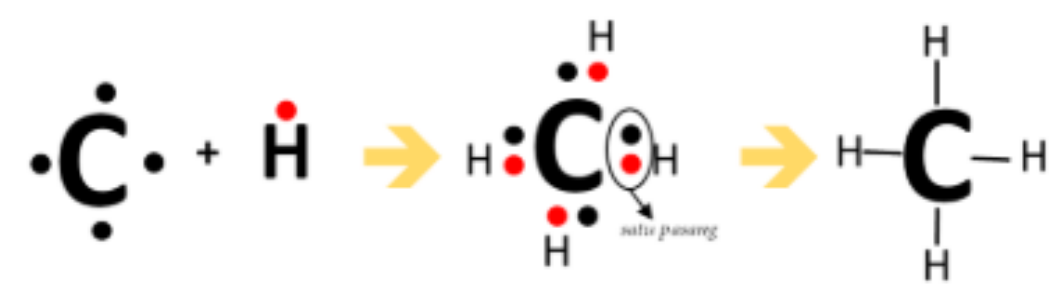

Gambar 3.6 Ikatan Kovalen Tunggal

2. Ikatan Kovalen Ganda (rangkap 2), Ikatan kovalen ganda terjadi apabila dua atom yang berpasangan masing-masing menyerahkan dua elektron yang kemudian dipakai bersama. Hal ini terjadi pada $\mathrm{O} 2$, dimana $\mathrm{O}$ masing-masing menyerahkan 2 elektron, kemudian dipakai bersama-sama untuk berpasangan. Contoh senyawa yang berikatan ganda adalah : $\mathrm{C}$ dengan $\mathrm{O}$ pada $\mathrm{CO} 2, \mathrm{C}$ dengan $\mathrm{C}$ dalam $\mathrm{C} 2 \mathrm{H} 4$
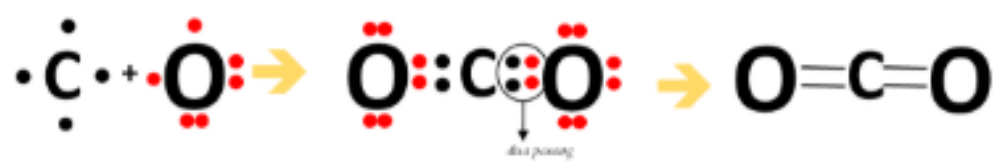

Gambar 3.7 Ikatan Kovalen Rangkap 2

3. Ikatan Kovalen Rangkap 3, Ikatan kovalen rangkap 3 terjadi apabila dua atom yang berpasangan masing-masing 
menyerahkan tiga elektron yang kemudian dipakai bersama. Hal ini terjadi pada N2, dimana N masing-masing menyerahkan 3 elektron, kemudian dipakai bersama-sama untuk berpasangan. Contoh senyawa yang berikatan rangkap 3 adalah : C dengan N pada $\mathrm{HCN}, \mathrm{C}$ dengan $\mathrm{C}$ dalam $\mathrm{C} 2 \mathrm{H} 2$
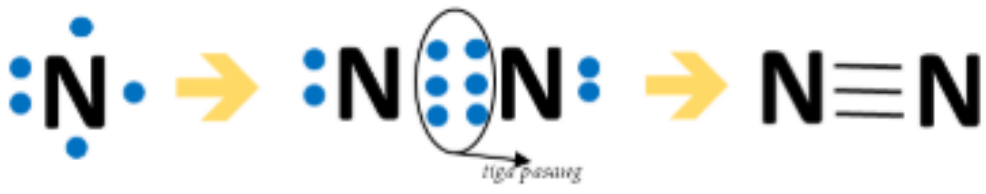

Gambar 3.8 Ikatan Kovalen Rangkap 3

4. Ikatan Kovalen Koordinasi, Ikatan kovalen koordinasi terjadi karena atom pusat memberikan electron kepada atom pasangan dan atom pasangan tidak memberikan electron untuk berpasangan namun atom pusat tetap menganggap electron yang diberikan tetap menjadi miliknya, lebih mirip menyewakan electron untuk berpasangan. 


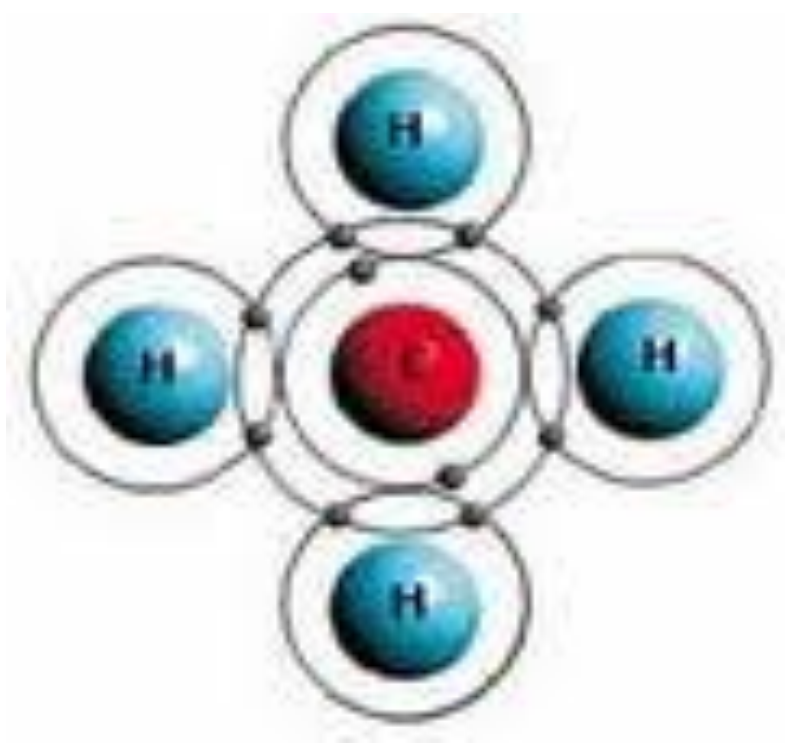

Gambar 3.9 Ikatan Kovalen

Sifat sebenarnya dari valensi tambahan (koordinasi) ini diungkapkan oleh kimiawan Inggris Nevil Vincent Sidgewick (18731952). la mengusulkan sejenis ikatan kovalen dengan pasangan elektron yang hanya disediakan oleh salah satu atom, yakni ikatan koordinasi. Jadi atom yang menerima pasangan elektron harus memiliki orbital kosong yang dapat mengakomodasi pasangan electron.

Contoh misalkan pada SO2 :

$16 \mathrm{~S}=2,8,6$ akan stabil dengan 2 elektron tambahan

$80=2,6$ akan stabil pula dengan 2 elektron tambahan 
Dalam SO2, S adalah atom pusat sehingga mempunyai kewajiban untuk memberikan 2 elektron kepada atom 0 yang kedua agar stabil, namun $\mathrm{S}$ sudah stabil karena berpasangan dengan atom Oksigen pertama, maka atom S cukup memberi saja. Kemudian S dengan atom Oksigen kedua inilah yang disebut dengan kovalen koordinasi, karena S sebagai atom pusat hanya memberi dan $\mathrm{O}$ menerima, namun electron tersebut tetap dipakai bersama. Contoh lain senyawa dengan ikatan koordinasi adalah $\mathrm{SO} 3, \mathrm{H} 2 \mathrm{SO} 3, \mathrm{H} 2 \mathrm{SO} 4$, HNO3 dan $\mathrm{H} 3 \mathrm{PO} 4$

5. Ikatan Logam, Dalam bentuk padat, atom-atom logam tersusun dalam susunan yang sangat rapat (closely packed). Susunan logam terdiri atas ion-ion logam dalam lautan electron. Dalam susunan seperti ini elektron valensinya relatif bebas bergerak dan tidak terpaku pada salah satu inti atom. Ikatan logam terjadi akibat interaksi antara elektron valensi yang bebas bergerak dengan inti atau kation-kation logam yang menghasilkan gaya tarik. Dalam percobaan sederhana dengan memukul arang dan besi, dapat dilihat bahwa arang (ikatan kovalen antarkarbon) akan hancur, sedangkan besi akan bengkok. Hal ini dapat terjadi karena lautan elektron pada kristal logam memegang erat ion-ion positif pada logam, sehingga apabila dipukul atau ditempa logam tidak akan pecah tercerai berai tetapi bergeser (terlihat bengkok). Hal inilah yang menyebabkan sifat logam ulet, dapat ditempa maupun diulur menjadi kawat. 

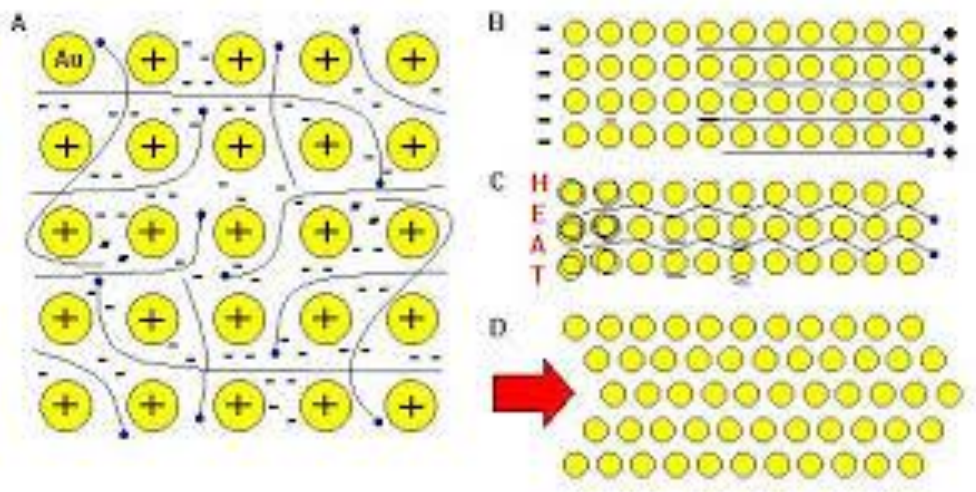

Gambar. 3.10 Ikatan Logam

Tingkat energi logam magnesium merupakan contoh teori pita yang baik Elektron yang ada di orbital $1 \mathrm{~s}, 2 \mathrm{~s}$ dan $2 \mathrm{p}$ berada di dekat inti, dan akibatnya terlokalisasi di orbital-orbital tersebut. Hal ini ditunjukkan di bagian bawah gambar. Namun, orbital 3s dan $3 p$ bertumpang tindih dan bercampur satu dengan yang lain membentuk MO. MO ini diisi elektron sebagian, sehingga elektronelektron ini secara terus menerus dipercepat oleh medan listrik menghasilkan arus listrik. Dengan demikian, magnesium adalah konduktor. Bila orbital-orbital valensi (s) terisi penuh, elektronelektron ini tidak dapat digerakkan oleh medan listrik kecuali elektron ini lompat dari orbital yang penuh ke orbital kosong di atasnya. Hal inilah yang terjadi dalam isolator. 


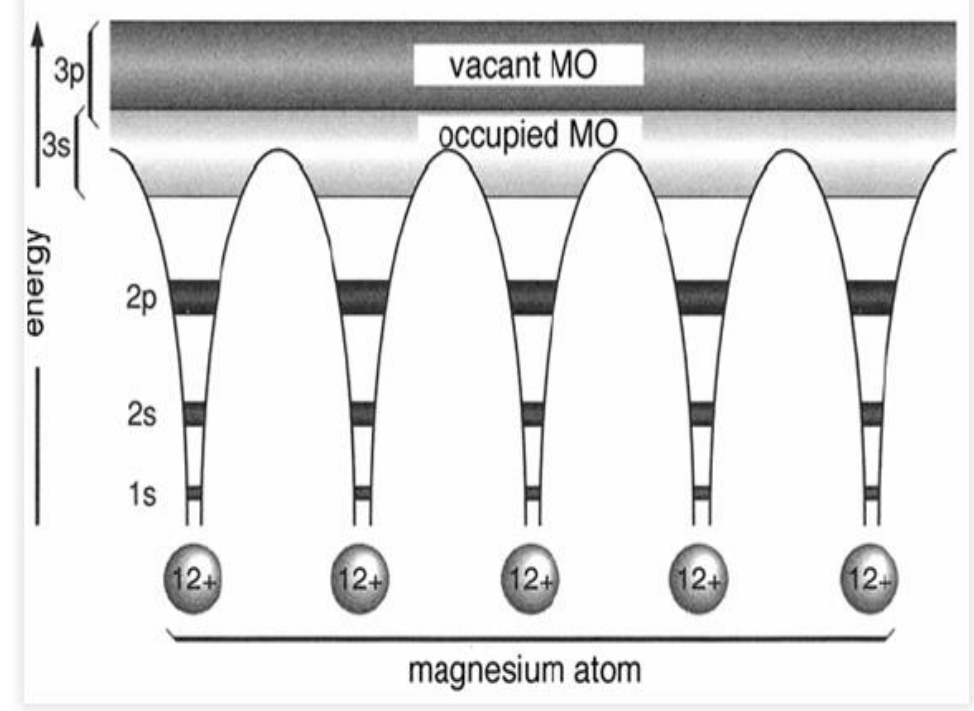

Gambar. 3.11 Penampang Orbital Atom Magnesium

Secara sederhana, jika sebuah electron $3 \mathrm{~s}$ dari magnesium melompat ke $3 p$ makan akan terbentuk sebuah jalan (pita) yang memberikan keleluasaan electron bergerak bebas dan mengalirkan listrik atau bisa juga disebut sebagai awan electron.

\subsection{Sifat Bahan Listrik}

Material ataua bahan bahan listrik mempunyai sifat sifat kelistrikan sebagai berikut :

1. Jika elektron bergerak bebas, mudah terjadi arus listrik, maka dapat disebut sebagai penghantar listrik (logam). 
2. Jika bahan mudah membentuk kutub positif dan negatif, memiliki sifat dielektrik, dapat disebut sebagai konduktor ion positif/negatif [keramik].

3. Jika elektron terikat pada atom, tidak mudah terjadi arus listrik, dapat disebut sebagai isolator atau non konduktor.

4. Jika bahan dielektrik diberi medan listrik cukup kuat yang melebihi "kekuatan dielektrik"nya, isolator dapat menjadi konduktor.

Untuk menentukan sifat sifat Bahan listrik jika ditinjau dari kemapuan menghantarkan arus, adalah sebagai berikut :

1. Tahanan : Kemampuan menahan arus listrik.

2. Konduktivitas : Kemampuan menghantarkan arus listrik.

3. Kekuatan dielektrik: Kemampuan menahan tembus tegangan (batas kemampuan isolasi bahan bila diberi tegangan tertentu sampai isolasinya bocor, arus mengalir)

\subsubsection{Konduktor}

Jenis bahan konduktor ini, meemiliki sifat : mempunyai nilai konduktifitas nya tinggi, sedangkan nilai resistivitasnya rendah. Oleh karenanya konduktr itu disebut sebagai penghantar karena mudah mengalirkan arus.

Adapun data dari Tahanan Jenis beberapa bahan adalah sebagai berikut :

1. Perak (Ag) $16 \mathrm{n} \Omega \mathrm{m}$.

2. Tembaga (Cu) $17 \mathrm{n} \Omega \mathrm{m}$.

3. Kuningan $(\mathrm{Cu}+\sim 30 \% \mathrm{Zn}) 70 \mathrm{n} \Omega \mathrm{m}$.

4. Nichrom $(\mathrm{Ni}+\mathrm{Cr}) 1 \mu \Omega \mathrm{m}$.

5. Grafit (C; semikond.) $35 \mu \Omega \mathrm{m}$. 
6. Silikon (Si) $2 \mathrm{k} \Omega \mathrm{m}$.

7. Karet (C-isolator) $\sim 1 \mathrm{M} \Omega \mathrm{m}$.

8. Kaca (SiO2) $\sim 1 \mathrm{~T} \Omega \mathrm{m}$.

9. Teflon (PTFE) $\sim 100 \mathrm{~T} \Omega \mathrm{m}$

Data dielektrika (Kemampuan untuk menahan tegangan tembus) bahan sebagai berikut:

1. Udara $(\mathrm{N} 2, \mathrm{O} 2) 3 \mathrm{MV} / \mathrm{m}$.

2. Lilin $(\mathrm{C}, \mathrm{H}) 10 \mathrm{MV} / \mathrm{m}$.

3. Kaca (SiO2) $14 \mathrm{MV} / \mathrm{m}$.

4. Kertas $16 \mathrm{MV} / \mathrm{m}$.

5. Polistirena (styrofoam) $24 \mathrm{MV} / \mathrm{m}$.

6. Teflon $60 \mathrm{MV} / \mathrm{m}$

Jika tubuh manusia menjadi konduktor, dan dialiri > 1mA, jantungnya dapat kacau denyutnya, di samping terjadi konversi energi listrik menjadi energi termal.

\subsubsection{Isolator Listrik}

Jenis bahan isolator memiliki sifat sifat bahan sebagai berikut :

1. Atomnya dapat terpolarisasi oleh medan listrik dari luar; "terjadi muatan (ter)induksi"; disebut "bahan dielektrik"..

2. Atom-atomnya dapat membentuk gugus terpolarisasi permanen :

- jika orientasi dipol listriknya acak, bahannya "para-elektrik"; dapat agak diorientasikan oleh medan listrik luar. 
- jika orientasi dipol listrik antar-tetangga saling menyejajarkan, bahannya "fero-elektrik"; orientasinya amat mengurangi pengaruh medan listrik luar dalam bahan.

Bahan jenis isolator ini akan dapat berubah menjdi semi konduktor dengan karakteristik sebagai berikut :

1. Jika atom agak mudah melepas elektron (misalnya oleh naiknya suhu), atau hadir atom asing yang agak mudah dapat menangkap elektron.

2. Bahan itu lalu disebut "semikonduktor" yang 'intrinsik', atau ekstrinsik $n$ (jika ada pelepasan elektron), ekstrinsik $\mathrm{p}$ (jika ada penangkapan elektron, dan pergeseran elektron lain mengesankan ada muatan positif, 'lubang' bergerak)

Pada bahan isolator untuk melakukan penujian apakah isolator itu masih mempunyai kemampuan untuk menghalangi arus dan tegangan yanag lewat, maka perlu diketahui Komstanta dielektriknya. Konstanta dielektrik beberapa bahan adalah sebagai berikut :

1. Vakum 1.

2. Udara 1,00054 .

3. Lilin, teflon $\sim 2$.

4. Polistirena 2,5.

5. Kertas 3,7.

6. Kaca biasa $\sim 4$.

7. Kaca pireks $4-6$

Berkaitan dengan sifat dielektrik bahan, maka bahn atau material listrik memiliki sifat sifat : 
1. Bersifat juga "piezo-elektrik" :

2. Jika diberi medan listrik, terorientasi sambil mengkerut / mengembang ("elektro-striksi", "electrostriction");

3. Jika ditekan, terjadi beda potensial listrik padanya. Manfaat : untuk mikrofon, sonar, pengukur regangan \& tekanan darah, akselerometer, peng-emulsi \& penghomogen susu \& cat.

4. Jika dipanaskan ke atas "suhu Curie"nya, menjadi paraelektrik.

\subsubsection{Semi Konduktor}

Semikonduktor adalah bahan yang sifat-sifat kelistrikannya terletak antara sifat-sifat konduktor dan isolator. Sifat-sifat kelistrikan konduktor maupun isolator tidak mudah berubah oleh pengaruh temperatur, cahaya atau medan magnet, tetapi pada semikonduktor sifat-sifat tersebut sangat sensitive.

Dalam mempelajari elektronika kita mengenal semikonduktor tipe $\mathrm{P}$ dan semikonduktor tipe $\mathrm{N}$. Kedua jenis semikonduktor tersebut merupakan bahan dari pembuatan komponen semikonduktor seperti dioda dan transistor. semikonduktor tipe $\mathbf{P}$ dan tipe $\mathrm{N}$ tersebut dapat dibuat menggunakan bahan silikon dan germanium. Oleh karena itu perlu kita ketahui tentang teori atom untuk memahami asal dari semikonduktor tersebut.

Elemen terkecil dari suatu bahan yang masih memiliki sifat-sifat kimia dan fisika yang sama adalah atom. Suatu atom terdiri atas tiga partikel dasar, yaitu: neutron, proton, dan elektron. Dalam struktur atom, proton dan neutron membentuk inti atom yang bermuatan positip, sedangkan elektron-elektron yang bermuatan negatip mengelilingi inti. Elektron-elektron ini tersusun berlapis-lapis. 
Struktur atom dengan model Bohr dari bahan semikonduktor yang paling banyak digunakan adalah silikon dan germanium.

Seperti ditunjukkan pada gambar dibawah atom silikon mempunyai elektron yang mengorbit (mengelilingi inti) sebanyak 14 dan atom germanium mempunyai 32 elektron. Pada atom yang seimbang (netral) jumlah elektron dalam orbit sama dengan jumlah proton dalam inti. Muatan listrik sebuah elektron adalah: $-1.602^{-19}$ C dan muatan sebuah proton adalah: $+1.602^{-19} \mathrm{C}[15]$.

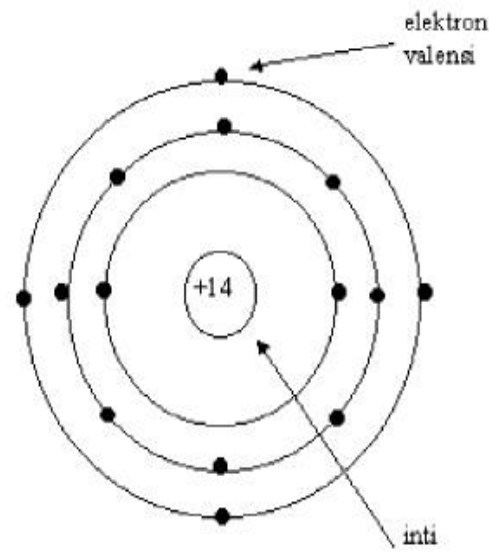

Silikon

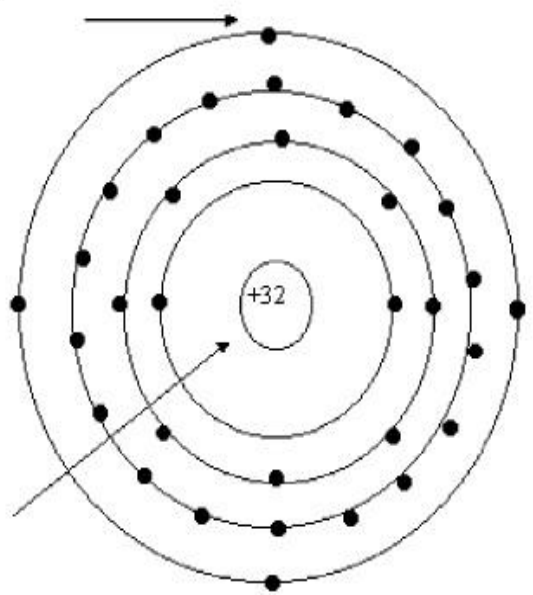

Germanium

Gambar 3.12 Struktur Atom Silikon Dan Germanium

Elektron yang menempati lapisan terluar disebut sebagai elektron valensi. Atom silikon dan germanium masing mempunyai empat elektron valensi. Oleh karena itu baik atom silikon maupun atom 
germanium disebut juga dengan atom tetra-valent (bervalensi empat). Empat elektron valensi tersebut terikat dalam struktur kisikisi, sehingga setiap elektron valensi akan membentuk ikatan kovalen dengan elektron valensi dari atom-atom yang bersebelahan. Struktur kisi-kisi kristal silikon murni dapat digambarkan secara dua dimensi.

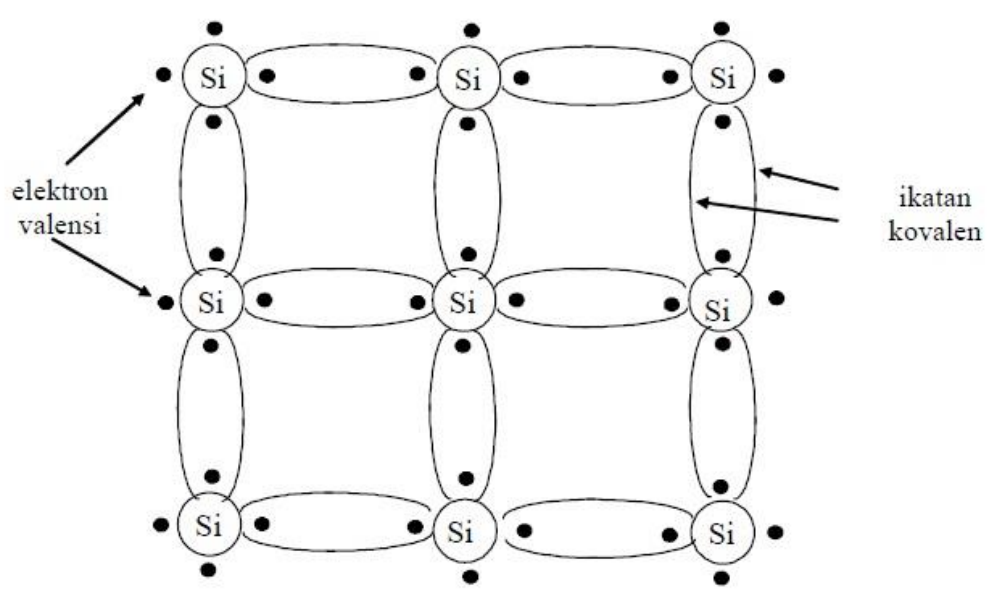

Gambar 3.13 Struktur Kristal Silikon dengan Ikatan Kovalen

Meskipun terikat dengan kuat dalam struktur kristal, namun bisa saja elektron valensi tersebut keluar dari ikatan kovalen menuju daerah konduksi apabila diberikan energi panas. Bila energi panas tersebut cukup kuat untuk memisahkan elektron dari ikatan kovalen maka elektron tersebut menjadi bebas atau disebut dengan elektron bebas. Pada suhu ruang terdapat kurang lebih 1.5 × 1010 elektron bebas dalam $1 \mathrm{~cm} 3$ bahan silikon murni (intrinsik) dan 2.5 x 1013 elektron bebas pada germanium. Semakin besar energi panas yang diberikan semakin banyak jumlah elektron bebas yang 
keluar dari ikatan kovalen, dengan kata lain konduktivitas bahan meningkat[11].

\section{Semikonduktor Tipe $\mathbf{N}$}

Apabila bahan semikonduktor intrinsik (murni) diberi (didoping) dengan bahan bervalensi lain maka diperoleh semikonduktor ekstrinsik. Pada bahan semikonduktor intrinsik, jumlah elektron bebas dan holenya adalah sama. Konduktivitas semikonduktor intrinsik sangat rendah, karena terbatasnya jumlah pembawa muatan yakni hole maupun elektron bebas tersebut. Jika bahan silikon didoping dengan bahan ketidak murnian (impuritas) bervalensi lima (penta-valens), maka diperoleh semikonduktor tipe n. Bahan dopan yang bervalensi lima ini misalnya antimoni, arsenik, dan pospor. Struktur kisi-kisi kristal bahan silikon type $\mathrm{n}$ dapat dilihat pada gambar berikut.

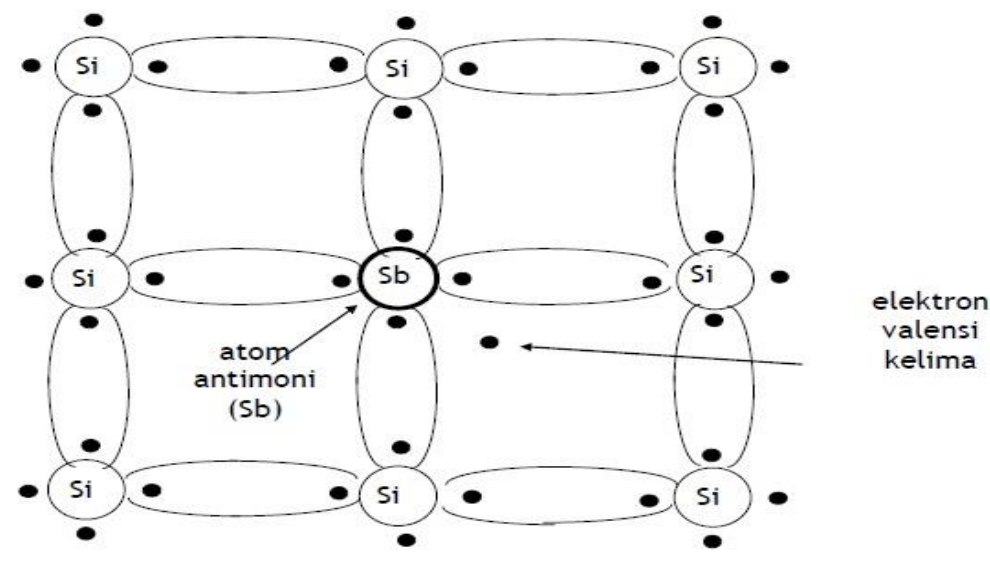

Gambar 3.14 Struktur Kristal Semikonduktor (Silikon) Tipe N 
Karena atom antimoni (Sb) bervalensi lima, maka empat elektron valensi mendapatkan pasangan ikatan kovalen dengan atom silikon sedangkan elektron valensi yang kelima tidak mendapatkan pasangan. Oleh karena itu ikatan elektron kelima ini dengan inti menjadi lemah dan mudah menjadi elektron bebas. Karena setiap atom depan ini menyumbang sebuah elektron, maka atom yang bervalensi lima disebut dengan atom donor. Dan elektron "bebas" sumbangan dari atom dopan inipun dapat dikontrol jumlahnya atau konsentrasinya.

Meskipun bahan silikon type $\mathrm{n}$ ini mengandung elektron bebas (pembawa mayoritas) cukup banyak, namun secara keseluruhan kristal ini tetap netral karena jumlah muatan positip pada inti atom masih sama dengan jumlah keseluruhan elektronnya. Pada bahan type $\mathrm{n}$ disamping jumlah elektron bebasnya (pembawa mayoritas) meningkat, ternyata jumlah holenya (pembawa minoritas) menurun. Hal ini disebabkan karena dengan bertambahnya jumlah elektron bebas, maka kecepatan hole dan elektron ber-rekombinasi (bergabungnya kembali elektron dengan hole) semakin meningkat. Sehingga jumlah holenya menurun.

Level energi dari elektron bebas sumbangan atom donor dapat digambarkan seperti pada gambar dibawah. Jarak antara pita konduksi dengan level energi donor sangat kecil yaitu $0.05 \mathrm{eV}$ untuk silikon dan $0.01 \mathrm{eV}$ untuk germanium. Oleh karena itu pada suhu ruang saja, maka semua elektron donor sudah bisa mencapai pita konduksi dan menjadi elektron bebas. 


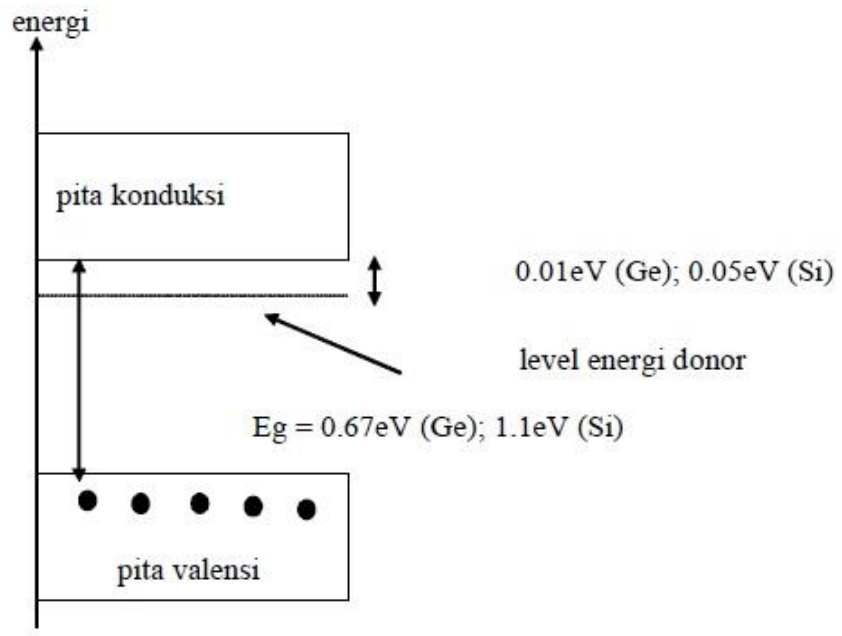

Gambar 3. 15 Diagram Pita Energi Semikonduktor Tipe N

Bahan semikonduktor tipe $\mathrm{n}$ dapat dilukiskan seperti pada gambar dibawah. Karena atom-atom donor telah ditinggalkan oleh elektron valensinya (yakni menjadi elektron bebas), maka menjadi ion yang bermuatan positip. Sehingga digambarkan dengan tanda positip. Sedangkan elektron bebasnya menjadi pembawa mayoritas. Dan pembawa minoritasnya berupa hole.



Gambar 3.16 Bahan Semikonduktor Tipe N 


\section{Semikonduktor Tipe $\mathbf{P}$}

Apabila bahan semikonduktor murni (intrinsik) didoping dengan bahan impuritas (ketidak-murnian) bervalensi tiga, maka akan diperoleh semikonduktor type $\mathrm{p}$. Bahan dopan yang bervalensi tiga tersebut misalnya boron, galium, dan indium. Struktur kisi-kisi kristal semikonduktor (silikon) type $\mathrm{p}$ adalah seperti gambar dibawah.

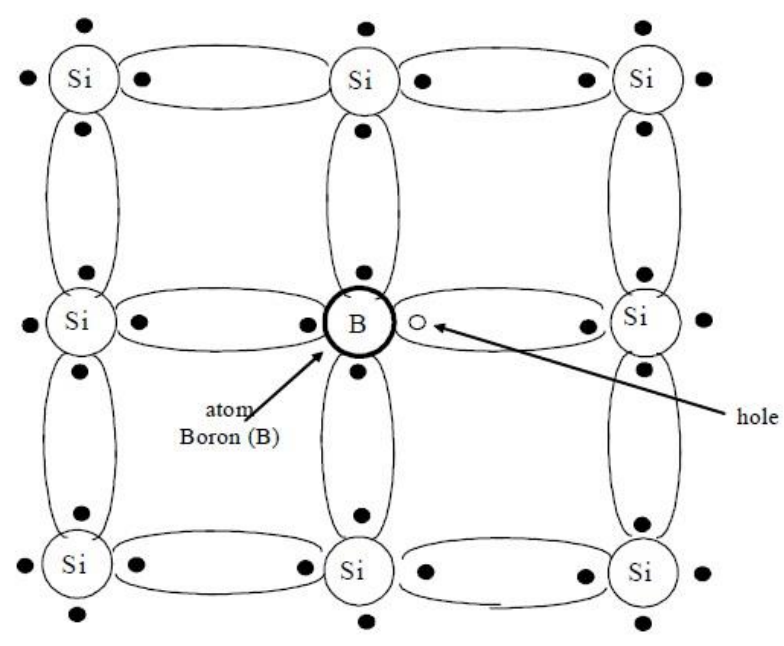

Gambar 3.17 Struktur Kristal Semikonduktor (Silikon) Tipe P

Karena atom dopan mempunyai tiga elektron valensi, dalam gambar diatas adalah atom Boron (B), maka hanya tiga ikatan kovalen yang bisa dipenuhi. Sedangkan tempat yang seharusnya membentuk ikatan kovalen keempat menjadi kosong (membentuk hole) dan bisa ditempati oleh elektron valensi lain. Dengan demikian sebuah atom bervalensi tiga akan menyumbangkan 
sebuah hole. Atom bervalensi tiga (trivalent) disebut juga atom akseptor, karena atom ini siap untuk menerima elektron.

Seperti halnya pada semikonduktor type n, secara keseluruhan kristal semikonduktor type $\mathrm{n}$ ini adalah netral. Karena jumlah hole dan elektronnya sama. Pada bahan type $p$, hole merupakan pembawa muatan mayoritas. Karena dengan penambahan atom dopan akan meningkatkan jumlah hole sebagai pembawa muatan. Sedangkan pembawa minoritasnya adalah elektron.

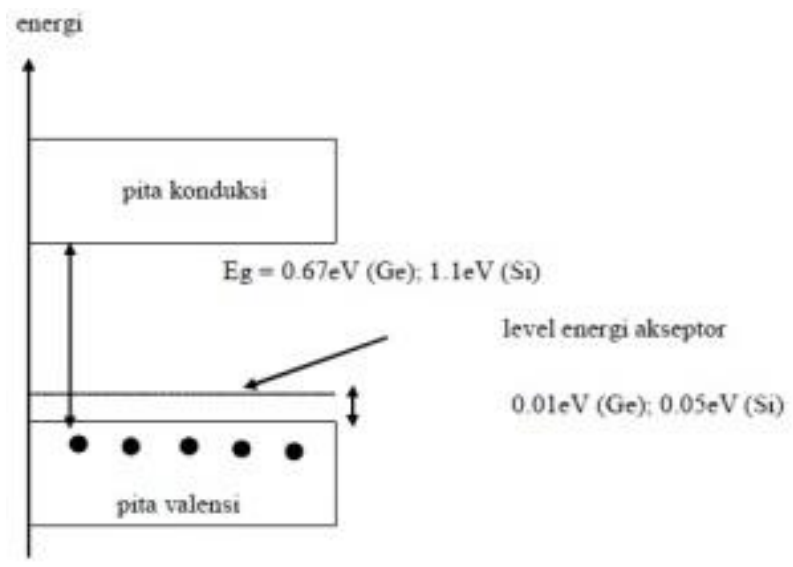

Gambar 3.18 Diagram Pita Energi Semikonduktor Tipe P

Level energi dari hole akseptor dapat dilihat pada gambar diatas. Jarak antara level energi akseptor dengan pita valensi sangat kecil yaitu sekitar $0.01 \mathrm{eV}$ untuk germanium dan $0.05 \mathrm{eV}$ untuk silikon. Dengan demikian hanya dibutuhkan energi yang sangat kecil bagi elektron valensi untuk menempati hole di level energi 
akseptor. Oleh karena itu pada suhur ruang banyak sekali jumlah hole di pita valensi yang merupakan pembawa muatan.

Bahan semikonduktor tipe $\mathrm{p}$ dapat dilukiskan seperti pada gambar dibawah. Karena atom-atom akseptor telah menerima elektron, maka menjadi ion yang bermuatan negatip. Sehingga digambarkan dengan tanda negatip. Pembawa mayoritas berupa hole dan pembawa minoritasnya berupa elektron.



Gambar 3.19 Bahan Semikonduktor Tipe P

\subsubsection{Keramik}

Keramik memiliki karakteristik yang memungkinkannya digunakan untuk berbagai aplikasi termasuk :

1. Kapasitas panas yang baik dan konduktivitas panas yang rendah. 
2. Tahan korosi, Sifat listriknya dapat insulator, semikonduktor, konduktor bahkan superkonduktor. Sifatnya dapat magnetik dan non-magnetik.

3. Keras dan kuat, namun rapuh.

Dua jenis ikatan dapat terjadi dalam keramik, yakni ikatan ionik dan kovalen. Sifat keseluruhan material bergantung pada ikatan yang dominan. Klasifikasi

Bahan keramik dapat dibedakan menjadi dua kelas : kristalin dan amorf (non kristalin). Dalam material kristalin terdapat keteraturan jarak dekat maupun jarak jauh, sedang dalam material amorf mungkin keteraturan jarak pendeknya ada, namun pada jarak jauh keteraturannya tidak ada. Beberapa keramik dapat berada dalam kedua bentuk tersebut, misalnya SiO2,

Jenis ikatan yang dominan (ionik atau kovalen) dan struktur internal (kristalin atau amorf) mempengaruhi sifat-sifat bahan keramik. Sifat termal. Sifat termal penting bahan keramik adalah kapasitas panas, koefisien ekspansi termal, dan konduktivitas termal. Kapasitas panas bahan adalah kemampuan bahan untuk mengabsorbsi panas dari lingkungan. Panas yang diserap disimpan oleh padatan antara lain dalam bentuk vibrasi (getaran) atom/ion penyusun padatan tersebut.

Keramik biasanya memiliki ikatan yang kuat dan atom-atom yang ringan. Jadi getaran-getaran atom-atomnya akan berfrekuensi tinggi dan karena ikatannya kuat maka getaran yang besar tidak akan menimbulkan gangguan yang terlalu banyak pada kisi kristalnya.

Hantaran panas dalam padatan melibatkan transfer energi antar atom-atom yang bervibrasi. Vibrasi atom akan mempengaruhi gerakan atom-atom lain di tetangganya dan 
hasilnya adalah gelombang yang bergerak dengan kecepatan cahaya yakni fonon. Fonon bergerak dalam bahan sampai terhambur baik oleh interaksi fonon-fonon maupun cacat kristal.

Keramik amorf yang mengandung banyak cacat kristal menyebabkan fonon selalu terhambur sehingga keramik merupakan konduktor panas yang buruk. Mekanisme hantaran panas oleh elektron, yang dominan pada logam, tidak dominan di keramik karena elektron di keramik sebagian besar terlokalisasi.

Contoh paling baik penggunaan keramik untuk insulasi panas adalah pada pesawat ruang angkasa. Hampir semua permukaan pesawat tersebut dibungkus keramik yang terbuat dari serat silika amorf. Titik leleh aluminium adalah 660 oC. Ubin menjaga suhu tabung pesawat yang terbuat dari Al pada atau dibawah 175 oC, walaupun eksterior pesawat mencapau 1400 oC. Sifat Optik

Bila cahaya mengenai suatu obyek cahaya dapat ditransmisikan, diabsorbsi, atau dipantulkan. Bahan bervariasi dalam kemampuan untuk mentransmisikan cahaya, dan biasanya dideskripsikan sebagai transparan, translusen, atau opaque. Material yang transparan, seperti gelas, mentransmisikan cahaya dengan difus, seperti gelas terfrosted, disebut bahan translusen. Batuan yang opaque tidak mentransmisikan cahaya.

Dua mekanisme penting interaksi cahaya dengan partikel dalam padatan adalah polarisasi elektronik dan transisi elektron antar tingkat energi. Polarisasi adalah distorsi awan elektron atom oleh medan listrik dari cahaya. Sebagai akibat polarisasi, sebagian energi dikonversikan menjadi deformasi elastik (fonon), dan selanjutnya panas.

Seperti dalam atom elektron-elektron dalam bahan berada dalam tingkat-tingkat energi tertentu. Absorbsi energi menghasilkan perpindahan elektron dari tingkat dasar ke tingkat 
tereksitasi. Ketika elektron kembali ke keadaan dasar disertai dengan pemancaran radiasi elektromagnetik.

Dalam padatan elektron yang energinya tertinggi ada dalam orbital-orbital dalam pita valensi dan orbital-orbital yang tidak terisi biasanya dalam pita konduksi. Gap antara pita valensi dan pita konduksi disebut gap energi. Range energi cahaya tampak 1,8 sampai 3,1 eV. Bahan dengan gap energi di daerah ini akan mengabsorbsi energi yang berhubungan. Bahan itu akan tampak transparan dan berwarna. Contohnya, gap energi CdS sekitar 2,4 eV dan mengabsorbsi komponen cahaya biru dan violet dari sinar tampak. Tampak bahan tersebut berwarna kuning-oranye.

Bahan dengan gap energi kurang dari 1,8 eV akan opaque, sebab semua cahaya tampak akan diabsorbsi. Material dengan gap energi lebih besar 3,1 eV tidak akan menyerap range sinar tampak dan akan tampak transparan dan tak berwarna. Cahaya yang diemisikan dari transisi elektron dalam padatan disebut luminesensi. Bila terjadi dalam selang waktu yang pendek disebut flouresensi, bila didalam selang waktu yang lebih panjang disebut fosforisensi.

Cahaya yang ditransmisikan dari satu medium ke medium lain, misalnya dari gelas ke air akan mengalami pembiasan. Pembelokan cahaya ini adalah akibat perubahan kecepatan rambat yang asal mulanya dari polarisasi elektronik. Karena polarisasi meningkat dengan naiknya ukuran atom. Gelas yang mengandung ion-ion berat (seperti kristal timbal) memiliki indeks bias yang lebih besar dari gelas yang mengandung atom-atom ringan (seperti gelas soda).

Hamburan cahaya internal dalam bahan yang sebenarnya transparan mungkin dapat mengakibatkan bahan menjadi translusen atau opaque. Hamburan semacam ini terjadi antara lain di batas butiran, batas fasa, dan pori-pori. 
Banyak aplikasi memanfaatkan sifat optik bahan keramik ini. Transparansi gelas membuatnya bermanfaat untuk jendela, lensa, filter, alat masak, alat lab, dan objek-objek seni. Pengubahan antara cahaya dan listrik adalah dasar penggunaan bahan semikonduktor seperti GaAs dalam laser dan meluasnya penggunaan LED dalam alat-alat elektronik. Keramik fluoresensi dan fosforisensi digunakan dalam lampu-lampu listrik dan layar-layar tv. Akhirnya serat optik mentransmisikan percakapan telepon dan data komputer yang didasarkan atas refleksi internal total sinyal cahaya.

\subsection{Sifat Bahan}

\subsubsection{Sifat Mekanik}

Keramik biasanya material yang kuat, dan keras dan juga tahan korosi. Sifat-sifat ini bersama dengan kerapatan yang rendah dan juga titik lelehnya yang tinggi, membuat keramik merupakan material struktural yang menarik.

Aplikasi struktural keramik maju termasuk komponen untuk mesin mobil dan struktur pesawat. Misalnya, TiC mempunyai kekerasan 4 kali kekerasan baja. Jadi, kawat baja dalam struktur pesawat dapat diganti dengan kawat TiC yang mampu menahan beban yang sama hanya dengan diameter separuhnya dan 31 persen berat. Semen dan tanah liat adalah contoh yang lain, keduanya dapat dibentuk ketika basah namun ketika kering akan menghasilkan objek yang lebih keras dan lebih kuat. Material yang sangat kuat seperti alumina (Al2O3) dan silikon karbida (SiC) digunakan sebagai abrasif untuk grinding dan polishing.

Keterbatasan utama keramik adalah kerapuhannya, yakni kecenderungan untuk patah tiba-tiba dengan deformasi plastik yang sedikit. Ini merupakan masalah khusus bila bahan ini digunakan untuk aplikasi struktural. Dalam logam, elektron- 
Elektron yang terdelokalisasi memungkinkan atom-atomnya berubah-ubah tetangganya tanpa semua ikatan dalam strukturnya putus. Hal inilah yang memungkinkan logam terdeformasi di bawah pengaruh tekanan. Tapi, dalam keramik, karena kombinasi ikatan ion dan kovalen, partikel-partikelnya tidak mudah bergeser. Keramiknya dengan mudah putus bila gaya yang terlalu besar diterapkan.

Faktur rapuh terjadi bila pembentukan dan propagasi keretakan yang cepat. Dalam padatan kristalin, retakan tumbuh melalui butiran (trans granular) dan sepanjang bidang cleavage (keretakan) dalam kristalnya. Permukaan tempat putus yang dihasilkan mungkin memiliki tekstur yang penuh butiran atau kasar. Material yang amorf tidak memiliki butiran dan bidang kristal yang teratur, sehingga permukaan putus kemungkinan besar mulus penampakannya.

Kekuatan tekan penting untuk keramik yang digunakan untuk struktur seperti bangunan. Kekuatan tekan keramik biasanya lebih besar dari kekuatan tariknya. Untuk memperbaiki sifat ini biasanya keramik di-pretekan dalam keadaan tertekan. Sifat Hantaran Listrik.

\subsubsection{Sifat Listrik}

Sifat listrik bahan keramik sangat bervariasi. Keramik dikenal sangat baik sebagai isolator. Beberapa isolator keramik (seperti BaTiO3) dapat dipolarisasi dan digunakan sebagai kapasitor.

Keramik lain menghantarkan elektron bila energi ambangnya dicapai, dan oleh karena itu disebut semikonduktor. Tahun 1986, keramik jenis baru, yakni superkonduktor temperatur kritis tinggi ditemukan. Bahan jenis ini di bawah suhu kritisnya memiliki hambatan $=0$. Akhirnya, keramik yang disebut sebagai piezoelektrik 
dapat menghasilkan respons listrik akibat tekanan mekanik atau sebaliknya.

Sering pula digunakan bahan yang disebut dielektrik. Bahan ini adalah isolator yang dapat dipolarisasi pada tingkat molekular. Material semacam ini digunakan untuk menyimpan muatan listrik.

Kekuatan dielektrik bahan adalah kemampuan bahan tersebut untuk menyimpan elektron pada tegangan tinggi. Bila kapasitor dalam keadaan bermuatan penuh, hampir tidak ada arus yang lewat. Namun dengan tegangan tinggi dapat mengeksitasi elektron dari pita valensi ke pita konduksi.

Bila hal ini terjadi arus mengalir dalam kapasitor, dan mungkin disertai dengan kerusakan material karena meleleh, terbakar atau menguap. Medan listrik yang diperlukan untuk menghasilkan kerusakan itu disebut kekuatan dielektrik. Beberapa keramik mempunyai kekuatan dielektrik yang sangat besar.Porselain misalnya sampai $160 \mathrm{kV} / \mathrm{cm}$. Sebagian besar hantaran listrik dalam padatan dilakukan oleh elektron. Di logam, elektron penghantar dihamburkan oleh vibrasi termal meningkat dengan kenaikan suhu, maka hambatan logam meningkat pula dengan kenaikan suhu.

Sebaliknya, elektron valensi dalam keramik tidak berada di pita konduksi, sehingga sebagian besar keramik adalah isolator. Namun, konduktivitas keramik dapat ditingkatkan dengan memberikan ketakmurnian. Energi termal juga akan mempromosikan elektron ke pita konduksi, sehingga dalam keramik, konduktivitas meningkat (hambatan menurun) dengan kenaikan suhu.

Beberapa keramik memiliki sifat piezoelektrik, atau kelistrikan tekan. Sifat ini merupakan bagian bahan "canggih" yang sering digunakan sebagai sensor. Dalam bahan piezoelektrik, penerapan gaya atau tekanan dipermukaannya akan menginduksi polarisasi 
dan akan terjadi medan listrik, jadi bahan tersebut mengubah tekanan mekanis menjadi tegangan listrik.

Bahan piezoelektrik digunakan untuk tranduser, yang ditemui pada mikrofon, dan sebagainya. Dalam bahan keramik, muatan listrik dapat juga dihantarkan oleh ion-ion. Sifat ini dapat diubahubah dengan merubah komposisi, dan merupakan dasar banyak aplikasi komersial, dari sensor zat kimia sampai generator daya listrik skala besar. Salah satu teknologi yang paling prominen adalah sel bahan bakar. Kemampuan penghantaran ion didasarkan kemampuan keramik tertentu untuk memungkinkan anion oksigen bergerak, sementara pada waktu yang sama tetap berupa isolator. Zirkonia, ZrO2, yang distabilkan dengan kalsia ( $\mathrm{CaO})$, adalah contoh padatan ionik.

\subsection{Tugas}

Jawablah pertayaan - pertanyaan berikut dengan singkat dan jelas:

1. Apakah yang disebut dengan ikatan ion, dan gambar kan posisi eleltron terhadap inti?

2. Apakah yang disebut dengan ikatan kovalen, dan gambar kan posisi eleltron terhadap inti?

3. Apakah yang disebut dengan ikatan logam, dan gambar kan posisi eleltron terhadap inti?

4. Bagaimana susunan pita energi konduktor?

5. Bagaimana susunan pita energi isolator?

6. Bagaimana susunan pita energi Semi konduktor ?

7. Mengapa pada ikatan logam dapat menghantarkan arus listrik? 


\section{DAFTAR PUSTAKA}

[1] M. Schuh, "The Elements of Physical Chemistry, 2nd. ed. (Atkins, P. W.)," J. Chem. Educ., 1998.

[2] J. Ahmad, "Elektronika Dasar 1," Elektron. Dasar 1, 2007.

[3] M. S. Silberberg and P. Amateis, Chemistry: The Molecular Nature of Matter and Change. 2015.

[4] T. L. Brown, H. E. J. Lemay, B. E. Bursten, C. J. Murphy, and P. M. Woodward, Chemistry, The Central Science. 2011.

[5] V. Mourik, K. Zuo, S. M. Frolov, S. R. Plissard, E. P. A. M. Bakkers, and L. P. Kouwenhoven, "Signatures of majorana fermions in hybrid superconductor-semiconductor nanowire devices," Science (80-. )., 2012.

[6] I. Manggolo, M. Ihsan, and M. Alaydrus, "Optimalisasi Perencanaan Jaringan Akses Serat Optik Fiber To The Home Menggunakan Algoritma Genetika," InComTech, J. Telekomun. dan Komput., 2007.

[7] S. N. Amir, R. H. Y. Subban, and N. S. Mohamed, "Ionic Conductivity of PEMA-LiClO4 Polymer Electrolytes (Kekonduksian Ion dalam Elektrolit Polimer PEMA-LiClO4 )," Sains Malaysiana, 2011.

[8] F. Semiconductor, "Freescale Semiconductor , I nc ... Freescale Semiconductor , I nc ...," System, 1994.

[9] A. I. Buzdin, "Proximity effects in superconductorferromagnet heterostructures," Rev. Mod. Phys., 2005. 
[10] i-lib Perpustakaan UGM, "Pembuatan Bahan Sensor Medan Magnet Ag-Fe Dan Analisis Resistivitasnya," J. i-lib UGM, 1999.

[11] S. C. Erwin, L. Zu, M. I. Haftel, A. L. Efros, T. A. Kennedy, and D. J. Norris, "Doping semiconductor nanocrystals," Nature, 2005.

[12] S. De Franceschi, L. Kouwenhoven, C. Schönenberger, and W. Wernsdorfer, "Hybrid superconductor-quantum dot devices," Nature Nanotechnology. 2010.

[13] A. M. Rambe, "Penggunaan Serat Optik Plastik Sebagai Media Transmisi Untuk Alat Ukur Temperatur Jarak Jauh," Seminar, 2002.

[14] A. Setiono, D. Hanto, and D. B. Widiyatmoko, "Investigasi Sensor Serat Optik untuk Aplikasi Sistem Pengukuran Berat Beban Berjalan (Weight in Motion System)," TELAAH J. Ilmu Pengetah. dan Teknol., 2013.

[15] M. Law, J. Goldberger, and P. Yang, "SEMICONDUCTOR NANOWIRES AND NANOTUBES," Annu. Rev. Mater. Res., 2004. 


\section{OTO BIOGRAFI PENULIS}

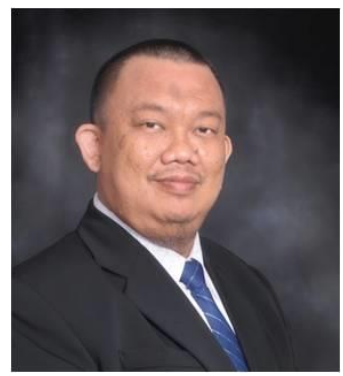

Jamaaluddin, lahir di Surabaya, 17 Oktober 1970, anak pertama dari lima bersaudara dari pasangan Drs. H. Isra' Kusnoto, Msi dan $\mathrm{Hj}$. Indah Rahayu. Penulis tercatat sebagai dosen tetap di Universitas Muhammadiyah Sidoarjo pada tahun 2013, pada Program Studi Teknik Elektro. Latar belakang Pendidikan pendidikan penulis dimulai pada jenjang Sekolah Dasar Pada SDN. Gading 1, Surabaya; Sekolah Menengah Pertama Negeri 9, Surabaya; Sekolah Menengah Pertama Negeri-1, Surabaya; dilanjutkan dengan pendidikan pada jenjang Strata-1 pada Universitas Brawijaya malang Jurusan Teknik Elektro dengan konsentrasi pada Sistem Tenaga Listrik lulus tahun 1992; Jenjang pendidikan Master dilakukannya pada Universitas Muhammadiyah Yogjakarta Jurusan Magister Manajemen dengan konsentrasi Manajemen Sumber Daya Manusia lulus pada tahun 2013; Mulai tahun 2015 penulis menempuh Studi Doktoral (S-3) pada Institut Teknologi Sepuluh Nopember Surabaya dengan konsentrasi pada Sistem Tenaga Listrik dengan rencana disertasi Tentang "Prediksi Beban Sistem Kelistrikan Jawa Bali". Dalam karirnya sebagai Dosen di UNIVERSITAS MUHAMMADIYAH SIDOARJO (UMSIDA) yang dilakukannya semenjak tahun 2013, penulis juga aktif dalam melakukan penelitian, utamanya berkaitan dengan kegiatan yang berkaitan dengan Sumber Daya Manusia, Bidang Konversi Energi Listrik pada bidang Energi Baru Terbarukan, dan pada Sistem Tenaga Listrik. Beberapa hasil penelitiannya sudah dipublikasikan baik secara Nasional maupun 
Internasional, seperti pada event IEEE Regional Asean, dan GCEAS di Hokkaido-Jappan. Semua penelitian yang dilakukan mendapatkan hibah baik dari KEMENRISTEK DIKTI maupun dari internal UMSIDA. Disamping aktif sebagai dosen tetap, penulis juga mempunyai beberapa usaha di bidang Kontraktor Elektrikal Mekanikal yang telah ditekuninya sejak tahun 2000, dan di bidang Umrah dan Haji Plus sejak tahun 2010. Beberapa buku sudah dibuat oleh penulis sejak usia muda antara lain : Pembuatan naskah skenario Drama Televisi pada tahun 1986 yang berjudul "Sang Darim"; Pembuatan buku yang berjudul "Perjalanan sebuah batu" pada tahun 1995; Buku "Bimbingan Manasik haji dan Umrah" pada tahun 2003; Buku "Tuntunan Doa Umrah dan Haji" pada tahun 2003; Buku "Aduhai Haji" pada tahun 2005; Buku "Pegangan Training Of Tour Leader Umrah dan Haji" pada tahun 2013; Buku "Pentanahan Sistem Tenaga Listrik" pada tahun 2016; dan buku ini yang berjudul "Ayo Menjadi Pewirausaha" yang berisikan tips menjadi pengusaha tahun 2017. Saat ini sebagai bentuk Catur Darma Perguruan Tinggi Muhammadiyah penulis juga menjadi Praktisi HYPNOTERAPHIST untuk membantu siapapun yang mengalami gangguan psikis, dan menjadi MOTIVATOR Kewirausahaan pada beberapa perusahaan, sekolah maupun perbankan. 


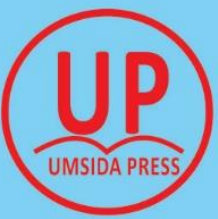

UMSIDA PRESS

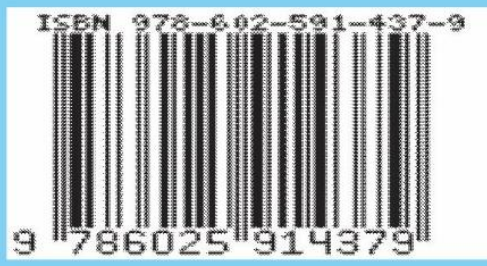

Jl. Mojopahit 666 B Sidoarjo 